\title{
CNS Drugs
}

\section{Medication-induced akathisia with newly approved antipsychotics in patients with a severe mental illness: a systematic review and meta-analysis --Manuscript Draft--}

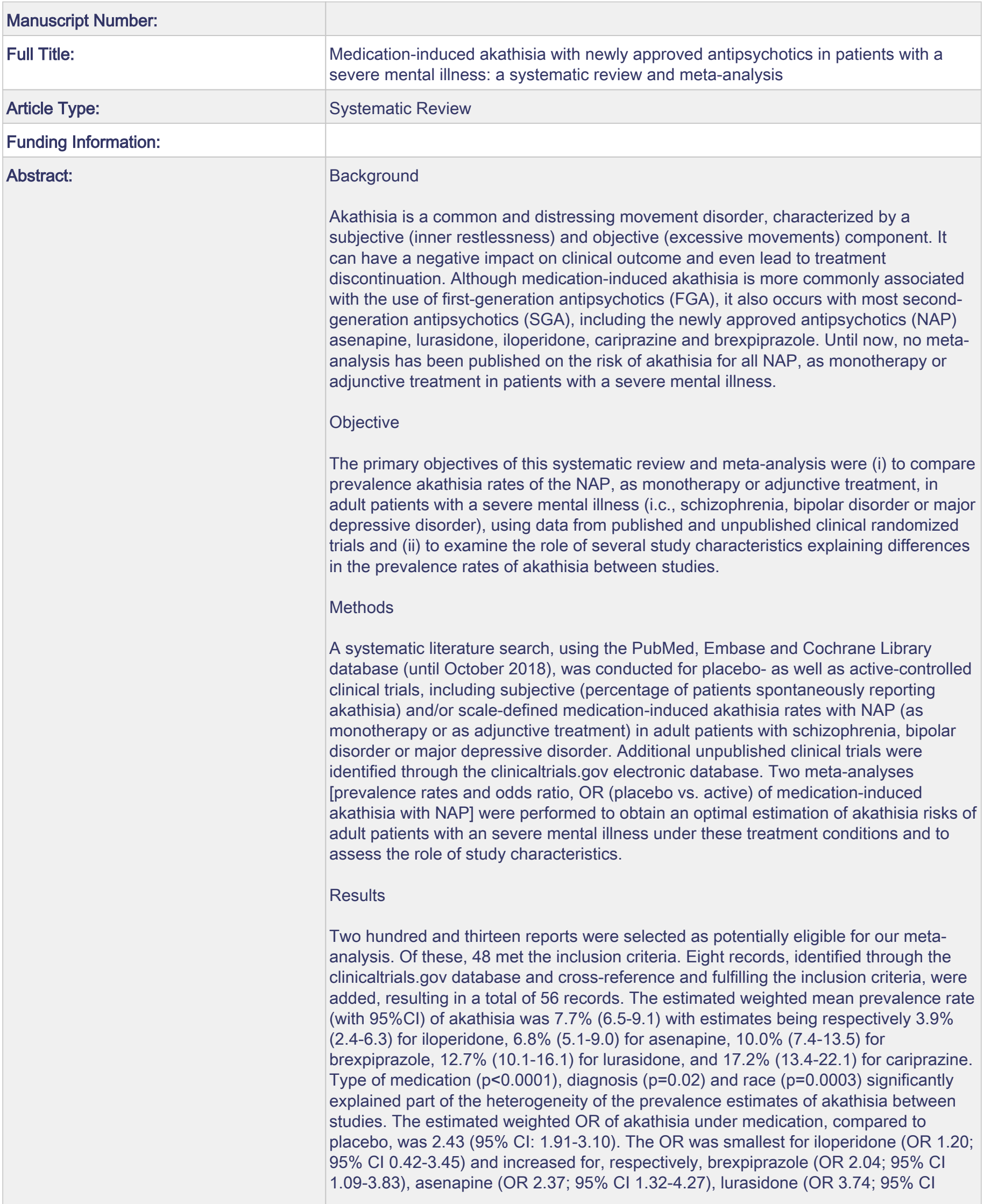


2.32-6.02) and cariprazine (OR 4.35; 95\% Cl 2.80-6.75). Only type of medication $(p=0.03)$ explained systematic differences in the OR for akathisia between placebo versus active treatment across studies. After Tukey-adjustment for multiple testing, no significant differences between these ORs were found. The severity of akathisia with NAP generally is mild to moderate, only in a minority of cases $(<5 \%)$ leading to treatment discontinuation.

\section{Conclusions}

The use of a NAP raises the akathisia risk more than two-fold, when compared to patients receiving placebo. Although distinctions between the different NAP were not clear in placebo controlled trials, generally the results of our meta-analyses and systematic review indicate that these differences more than likely reflect real differences, with iloperidone showing the most benign akathisia profile. Moreover, due to patient characteristics and methodological issues, prevalence rates of akathisia with NAP found in this meta-analysis may even be an underestimation of true prevalence rates.

\section{Corresponding Author:}

Johan Detraux, MA

KU Leuven - University

Kortenberg, BELGIUM

\section{Corresponding Author Secondary} Information:

Corresponding Author's Institution:

KU Leuven - University

Corresponding Author's Secondary Institution:

First Author:

Koen Demyttenaere, Prof

First Author Secondary Information:

Order of Authors:

Koen Demyttenaere, Prof

Johan Detraux, MA

Giorgio Racagni, Prof

Kristof Vansteelandt, PhD

Order of Authors Secondary Information:

Author Comments:

No comments

Suggested Reviewers: 
Medication-induced akathisia with newly approved antipsychotics in patients with a severe mental illness: a systematic review and meta-analysis.

\author{
Demyttenaere $\mathrm{K}^{1^{*}}$, Detraux $\mathrm{J}^{2 *}$, Racagni $\mathrm{G}^{3}$, Vansteelandt $\mathrm{K}^{2}$. \\ ${ }^{1}$ University Psychiatric Center KU Leuven and University of Leuven, Faculty of Medicine, \\ Department of Neurosciences, Research Group Psychiatry Department of Psychiatry, Leuven, \\ Belgium. \\ ${ }^{2}$ KU Leuven - University Psychiatric Centre, Department of Neurosciences, Research Group \\ Psychiatry, B-3070 Kortenberg Belgium. \\ ${ }^{3}$ Department of Pharmacological Sciences, Università degli Studi di Milano, Milan, Italy \\ *The first two authors contributed equally to this work.
}

Compliance with Ethical Standards

\title{
Conflicts of Interest
}

Koen Demyttenaere declares that he has received fees from Lundbeck, Servier, Boehringer Ingelheim, LivaNova, Pfizer, Recordati and Johnson \& Johnson in the past 3 years.

Giorgio Racagni declares that he has received personal fees from Servier and Recordati Johan Detraux and Kristof Vansteelandt have no conflict of interest.

\section{Funding}

No funding

\footnotetext{
Corresponding author: Koen Demyttenaere, University Psychiatric Center KU Leuven, Campus Gasthuisberg, Herestraat 49, 3000 Leuven, Belgium (Email: koen.demyttenaere@uzleuven.be)

Word count: 7,558
} 


\section{Abstract}

\section{Background}

Akathisia is a common and distressing movement disorder, characterized by a subjective (inner restlessness) and objective (excessive movements) component. It can have a negative impact on clinical outcome and even lead to treatment discontinuation. Although medicationinduced akathisia is more commonly associated with the use of first-generation antipsychotics (FGA), it also occurs with most second-generation antipsychotics (SGA), including the newly approved antipsychotics (NAP) asenapine, lurasidone, iloperidone, cariprazine and brexpiprazole. Until now, no meta-analysis has been published on the risk of akathisia for all $\mathrm{NAP}$, as monotherapy or adjunctive treatment in patients with a severe mental illness.

\section{Objective}

The primary objectives of this systematic review and meta-analysis were (i) to compare prevalence akathisia rates of the NAP, as monotherapy or adjunctive treatment, in adult patients with a severe mental illness (i.c., schizophrenia, bipolar disorder or major depressive disorder), using data from published and unpublished clinical randomized trials and (ii) to examine the role of several study characteristics explaining differences in the prevalence rates of akathisia between studies.

\section{Methods}

A systematic literature search, using the PubMed, Embase and Cochrane Library database (until October 2018), was conducted for placebo- as well as active-controlled clinical trials, including subjective (percentage of patients spontaneously reporting akathisia) and/or scaledefined medication-induced akathisia rates with NAP (as monotherapy or as adjunctive treatment) in adult patients with schizophrenia, bipolar disorder or major depressive disorder. Additional unpublished clinical trials were identified through the clinicaltrials.gov electronic database. Two meta-analyses [prevalence rates and odds ratio, OR (placebo vs. active) of medication-induced akathisia with NAP] were performed to obtain an optimal estimation of akathisia risks of adult patients with an severe mental illness under these treatment conditions and to assess the role of study characteristics.

\section{Results}

Two hundred and thirteen reports were selected as potentially eligible for our meta-analysis. Of these, 48 met the inclusion criteria. Eight records, identified through the clinicaltrials.gov database and cross-reference and fulfilling the inclusion criteria, were added, resulting in a total of 56 records. The estimated weighted mean prevalence rate (with 95\% CI) of akathisia was $7.7 \%$ (6.5-9.1) with estimates being respectively 3.9\% (2.4-6.3) for iloperidone, $6.8 \%$ (5.1-9.0) for asenapine, $10.0 \%$ (7.4-13.5) for brexpiprazole, $12.7 \%$ (10.1-16.1) for lurasidone, and 17.2\% (13.4-22.1) for cariprazine. Type of medication $(\mathrm{p}<0.0001)$, diagnosis $(\mathrm{p}=0.02)$ and race $(\mathrm{p}=0.0003)$ significantly explained part of the heterogeneity of the prevalence estimates of akathisia between studies. The estimated weighted OR of akathisia under medication, compared to placebo, was 2.43 (95\% CI: 1.91-3.10). The OR was smallest for iloperidone (OR 1.20; 95\% CI 0.42-3.45) and increased for, respectively, brexpiprazole (OR 2.04; 95\% CI 1.09-3.83), asenapine (OR 2.37; 95\% CI 1.32-4.27), lurasidone (OR 3.74; 95\% 
CI 2.32-6.02) and cariprazine (OR 4.35; $95 \%$ CI 2.80-6.75). Only type of medication $(\mathrm{p}=0.03)$ explained systematic differences in the OR for akathisia between placebo versus active treatment across studies. After Tukey-adjustment for multiple testing, no significant differences between these ORs were found. The severity of akathisia with NAP generally is mild to moderate, only in a minority of cases $(<5 \%)$ leading to treatment discontinuation.

\section{Conclusions}

The use of a NAP raises the akathisia risk more than two-fold, when compared to patients receiving placebo. Although distinctions between the different NAP were not clear in placebo controlled trials, generally the results of our meta-analyses and systematic review indicate that these differences more than likely reflect real differences, with iloperidone showing the most benign akathisia profile. Moreover, due to patient characteristics and methodological issues, prevalence rates of akathisia with NAP found in this meta-analysis may even be an underestimation of true prevalence rates.

\section{Key points}

Severe mental illness patients receiving a newly approved antipsychotic are more than twice as likely to suffer from akathisia, compared to those receiving placebo. Despite this, the severity of akathisia with these agents generally is mild to moderate, only in a minority of cases leading to treatment discontinuation.

Although distinctions between the different newly approved antipsychotics are not always clear in placebo controlled trials, with the exception of iloperidone, all these antipsychotics, as monotherapy or adjunctive treatment, likely are associated with moderate (asenapine and brexpiprazole) to high prevalence rates of akathisia (lurasidone and cariprazine) in patients with a severe mental illness.

As the included studies almost exclusively included samples with middle-aged patients and in many cases rely on spontaneous reporting, rather than on scale-defined akathisia to assess prevalence rates, akathisia rates found in this meta-analysis are expected to be an underestimate of actual outcome rates in daily clinical practice. 


\section{Background}

Acute akathisia: akathisia occurring within 6 weeks (usually within 2 or 3 weeks) of either initiating an antipsychotic medication, increasing the antipsychotic medication dose, or switching to a high-potency antipsychotic medication. The duration of symptoms and signs of acute akathisia do not exceed 3 months.

Chronic akathisia: akathisia that has been present for a long time (usually for more than 3 months).

Tardive akathisia: akathisia occurring late (usually after 3 months or more) during the course of treatment with antipsychotics. It is provoked or exacerbated by dose reduction or may even emerge after antipsychotic medication discontinuation. It often improves or attenuates, at least temporarily, when the dose is increased, but it may also persist for months or years even after the antipsychotic medication is discontinued. Tardive akathisia is indistinguishable in clinical appearance from acute akathisia.

Withdrawal akathisia: akathisia occurring within 2-6 weeks following dose reduction or cessation of an antipsychotic medication, or following dose reduction or discontinuation of an anticholinergic medication. It is considered to be phenomenologically indistinguishable from acute akathisia and generally disappears within about 6 weeks. If the akathisia persists for 
more than 6 weeks, it is no longer considered withdrawal akathisia but instead should be classified as tardive akathisia.

Persistent akathisia: akathisia that is particularly disabling and often refractory to treatment.

Pseudo-akathisia: this term has been used for the condition in which a patient exhibits the objective signs of akathisia in the absence of awareness of the typical subjective experience such a restlessness. It is not clear if pseudo-akathisia should actually be considered a "pseudo" form of the disorder, because many patients experience discomfort that they are unable to understand or express clearly. This form of akathisia therefore probably reflects a late stage of chronic akathisia, where the patient is either unable to verbalize the subjective dysphoria or this component has faded over time, or is a variant of tardive dyskinesia.

Subjective akathisia: akathisia that is essentially an abnormal subjective state. This is particularly evident in milder cases, as the signs of motor restlessness are not invariably present.

Bing-Sicard akathisia: akathisia occurring in parkinsonian disorders such as Parkinson's disease and post-encephalitic parkinsonism.

Hemi-akathisia: akathisia affecting only one side of the body.

Spontaneous akathisia: akathisia occurring in untreated patients.

When mild to moderate in severity, akathisia predominantly affects the lower extremities from the hips to the ankles $[2,4,7]$. With increasing severity, however, akathisia can involve the entire body [4].

Akathisia can have a negative impact on clinical outcome [13]. It may be disturbing for the patient and increase the risk of suicidal ideation and impulsive behavior, in extreme cases leading to suicide or aggressive behavior (homicide) $[7,15,16]$. Moreover, akathisia can become a cause of poor medication adherence and even treatment discontinuation $[4,16]$.

Medication-induced akathisia generally appears to be dose-related: the risk of this adverse drug reaction is greater in case of rapid dose increase, high-dose strategies or polypharmacy [17-22]. Medication-naïve patients are more sensible for this side effect $[1,3,4,13]$. Other risk factors may include negative symptoms, cognitive dysfunction, traumatic brain injury, cancer, a prior presence of substance abuse (especially cocaine), iron deficiency, prior akathisia, and concomitant parkinsonism. It also appears that patients with 
Akathisia with newly approved antipsychotics in severe mental illness patients

mood disorders, particularly bipolar disorder, may actually be at higher risk for medicationinduced akathisia. Although chronic and tardive akathisia may be associated with advanced age and female gender, there is no clear evidence that these factors are associated with a higher risk of acute akathisia $[4,8,10,13]$.

Currently, medication-induced akathisia is a diagnosis made purely by patient report and clinical observation [4]. Most studies, providing safety data for medications, mention the percentage of patients spontaneously reporting akathisia. They also provide in many cases data from rating scales that have been developed to identify and score the severity of akathisia [2]. The most widely used rating scale for the measurement of akathisia symptoms is the Barnes Akathisia Rating Scale (BARS) [2,4,5,11]. This 4-item scale includes a subjective (awareness of the presence of restlessness and any associated subjective distress) and objective assessment of akathisia, as well as a global clinical assessment of akathisia. The instrument is easy to administer and score, with established reliability, validity, and clinical utility $[1,2]$. Most studies using this rating scale define treatment-emergent akathisia as a total BARS score of 2 or more at (any) post-baseline assessment (assuming a total score of less than 2 at baseline). Another rating scale used in research is the Extrapyramidal Symptom Rating Scale (ESRS). This scale includes one item on the symptoms of akathisia, one item assessing objective signs of akathisia, and a Clinical Global Impression of Severity (CGI-S) of akathisia [1].

Although several medications across a number of categories, including antidepressants [particularly selective serotonin receptor inhibitors (SSRIs), such as paroxetine], calcium channel blockers, antibiotics (e.g., azithromycin), antiemetics (e.g., metoclopramide), and even illicit drugs (e.g., cocaine) can induce akathisia [1,3-5,7,10,12,23-27], it is principally seen in association with antipsychotic medication $[2,3,5]$. 
Akathisia with newly approved antipsychotics in severe mental illness patients

In 2009 and 2010, three new antipsychotics were approved by the U.S. Food and Drug Administration (FDA): asenapine (Saphris $\left.{ }^{\mathrm{TM}}\right)$, iloperidone $\left(\right.$ Fanapt $\left.^{\mathrm{TM}}\right)$, and lurasidone $\left(\right.$ Latuda $\left.^{\mathrm{TM}}\right)$. Later, in 2015, brexpiprazole $\left(\operatorname{Rexulti}^{\mathrm{TM}}\right)$ and cariprazine $\left(\operatorname{Vraylar}^{\mathrm{TM}}\right)$ have been added to the pantheon of antipsychotic medications. To get a fuller picture of the relationship between these antipsychotics and akathisia risk and because, at this moment, no meta-analysis has been published about this risk for all these agents as monotherapy, as well as adjunctive treatment in patients with severe mental illness, we have conducted a systematic review and meta-analysis on this topic.

\section{Objective}

The purpose of this systematic review was to examine the risk of akathisia with the newly approved antipsychotics (NAP) asenapine, iloperidone, lurasidone, brexpiprazole, and cariprazine, using data reported in randomized (placebo and/or active) controlled trials. A meta-analysis of akathisia outcomes was conducted to calculate drug-related risk. This information could aid clinicians in assessing the akathisia risks of the NAP and place them against the risk with the other available second generation antipsychotics (SGA).

\section{Methods}

\subsection{Literature Search}


Akathisia with newly approved antipsychotics in severe mental illness patients

results concerning the current state of knowledge about akathisia and its relationship to the

NAP in adult patients with a severe mental illness (schizophrenia, bipolar disorder or major depressive disorder). Following key words were used in various combinations:

'schizophrenia', 'bipolar disorder', or 'major depressive disorder/major depression', 'akathisia', and 'asenapine', 'iloperidone', 'lurasidone', ‘brexpiprazole', or 'cariprazine'. References of the identified studies and reviews were carefully cross-checked for additional relevant studies. We performed this systematic review in accordance with the 'Preferred Reporting Items for Systematic Reviews and Meta-analyses (PRISMA)' guidelines.

\subsection{Trial Selection}

For the meta-analysis we selected randomized controlled (placebo-controlled and/or active-controlled) trials. Individual clinical studies were included if:

1: they were written in English;

2: they included patients who were diagnosed with a schizophrenia spectrum or other psychotic disorder, bipolar disorder, or major depressive disorder;

3: they included at least one of the following outcome measures for akathisia:

- prevalence of akathisia

$\circ$ percentage of patients spontaneously reporting akathisia. In this metaanalysis, the terms 'akathisia' and 'restlessness' will be referred to only as 'akathisia'. For clinical studies with a record of both akathisia and restlessness, only the percentage of patients spontaneously reporting akathisia was considered.

$\bigcirc$ percentage of patients with scale-defined medication-induced akathisia: an objective assessment of akathisia using the BARS Global Clinical 
Akathisia with newly approved antipsychotics in severe mental illness patients

Assessment of Akathisia (item 4) score, with scores $\geq 2$ describing the objective diagnosis of akathisia $(0=$ absent, $1=$ questionable, $2=$ mild akathisia, $3=$ moderate akathisia, $4=$ marked akathisia, $5=$ severe akathisia).

- mean/median time to onset (i.c. the first time point at which akathisia was reported);

- mean/median duration: the duration (days/weeks) of akathisia;

- severity of akathisia: akathisia can be described as mild, moderate or severe;

- discontinuation rates: rates of discontinuation that were specifically due to akathisia.

\subsection{Statistical Analysis}

Two meta-analyses were conducted on the basis of the available studies. A first analysis was performed to obtain an optimal estimation of the prevalence of akathisia. Although the proportion was used as effect size (ES), all proportions were converted into logits as the mean proportion across studies underestimates the size of the confidence interval (CI) around the mean proportion (due to the compression of the standard error as p approaches 0 or 1) and overestimates the degree of heterogeneity across ESs [28]. The logit method circumvents these problems and therefore was the preferred method, especially given our interest in between study differences. For ease of interpretation, all final results were back-converted into proportions after analysis. Next, a second meta-analysis was performed to obtain an optimal estimate of the risk for akathisia under placebo versus active treatment conditions. In this meta-analysis, the Odds Ratio (OR) was the used ES to compare both groups is. We refrained from using the proportion difference because simulation studies have showed that this ES results in an 
Akathisia with newly approved antipsychotics in severe mental illness patients

underestimation of the $\mathrm{CI}$ around the mean proportion difference and a consistent overestimation of the amount of heterogeneity across ESs between studies [28]. However, because the OR has the inconvenient form of being asymmetrically centered around 1 rather than 0 , it is common practice to perform analyses on the natural Log of the OR (LOR), which is normally distributed. For ease of interpretation, all final results and CIs were back-converted into ORs after analysis.

To examine the homogeneity of the ES distribution in both meta-analyses, visual inspection and the Q-statistic were used [28]. When the 0-hypothesis is rejected by the Qstatistic, the ES distribution is not homogeneous, implying that the variability in the ESs between studies is larger than can be expected on the basis of sampling error (the error associated with the fact that the estimated ESs in the individual studies are based on different samples of subjects). In this case, we conducted a mixed random effects model implying that the observed variance stems from three sources: (a) variance due to subject-level sampling error, (b) variance from study characteristics that we could identify, (c) and variance from other systematic random or unmeasured sources. In both meta-analyses, several study characteristics were incorporated including (a) type of (active) medication (iloperidone, asenapine, lurasidone brexpiprazole, cariprazine), (b) diagnosis (schizophrenia vs. bipolar mania vs. major depression), (c) time of follow-up assessment (expressed in weeks), (d) titration time (expressed in days), (e) dosing (fixed versus flexible), and (f) race/ethnicity (proportion of Caucasians in the study).

To examine the possibility of publication bias, we used the Begg-Mazumder and Egger's bias test. 


\section{Results}

\subsection{Literature Search}

The original search in the PubMed, Embase and Cochrane Library databases yielded a total of 1,534 reports (asenapine: 369; iloperidone: 221; lurasidone: 473; brexpiprazole: 203; cariprazine: 268). Of these, 1,045 duplicate reports were removed (see Fig. 1). Overall, 213 references of published studies were selected as potentially eligible, of which 48 original records, identified on the basis of 68 publications, met the inclusion criteria. Six unpublished studies with results identified through the clinicaltrials.gov database, and 2 records identified through cross-reference and fulfilling the inclusion criteria, were added, resulting in a total of 56 original records (70 publications) [16-21, 29-97] (see supplementary online material for further details). The different studies of McIntyre et al. [35-38], Schoemaker [43,44] , Landbloom and Durgam [48, 49] and Loebel [91,92] were each counted as one as their pivotal or core study was followed by one or several extention trials containing patients from the original study. Table 1 (see electronic supplementary material) gives an overview of study characteristics and results of the included placebo and/or active-controlled records. 


\subsection{Meta-Analytic Results of Prevalence Rates of Medication-}

\section{Induced Akathisia with Newly Approved Antipsychotics}

Based on a meta-analysis involving 56 (placebo-and active controlled) studies with 16,302 unique patients, the estimated weighted mean prevalence rate of akathisia is $9.5 \%$ (95\% CI: 9.0-10.0). In Figure 2, the distribution of the estimated prevalence rates with $95 \%$ CIs of akathisia for each individual study, ordered from small to large, is depicted together with the weighted mean prevalence rate with 95\% CI for the Fixed Effects Model (FEM) (assuming only 
Akathisia with newly approved antipsychotics in severe mental illness patients

sampling error) and Random Effects Model (REM) (assuming variance from sampling error and other systematic random sources). The Q-statistic indicated that the distribution of akathisia prevalence rates of individual studies was not homogeneous $(\chi 2(55)=419.46, p<0.0001)$, implying that the variability in the prevalence rates of akathisia between studies is larger than can be expected on the basis of sampling error. Therefore, we estimated a Random Effects Model (REM), assuming that the variance of the prevalence rates of individual studies is due to subject-level sampling error and other (unknown) sources of systematic variation. As can be seen in this figure, the estimated prevalence rate of akathisia in the REM is 7.7\% (95\% CI: 6.59.1). Consequently, in a next step, we examined the potential role of several study characteristics to explain systematic differences in prevalence rates of akathisia between studies.

Figure 2: Distribution of estimated prevalence rates with $95 \%$ CIs of akathisia for each individual study 
Table 2. Prevalence rates of akathisia with newly approved antipsychotics

\begin{tabular}{|l|l|l|}
\hline $\begin{array}{l}\text { Newly approved } \\
\text { antipsychotic }\end{array}$ & $\begin{array}{l}\text { Prevalence rate of } \\
\text { akathisia }\end{array}$ & $\mathbf{9 5 \%}$ CI \\
\hline Iloperidone $^{\mathrm{a}}$ & $3.9 \%$ & $2.4 \%-6.3 \%$ \\
\hline Asenapine $^{\mathrm{ab}}$ & $6.8 \%$ & $5.1 \%-9.0 \%$ \\
\hline Brexpiprazole $^{\mathrm{bc}}$ & $10.0 \%$ & $7.4 \%-13.5 \%$ \\
\hline Lurasidone $^{\mathrm{cd}}$ & $12.7 \%$ & $10.1 \%-16.1 \%$ \\
\hline Cariprazine $^{\mathrm{d}}$ & $17.2 \%$ & $13.4 \%-22.1 \%$ \\
\hline
\end{tabular}

Note: ${ }^{\text {abcd }}$ Prevalence rates that do not share the same subscript are statistically significantly different after Tukey adjustment for multiple comparisons

Results indicate that type of medication, $(\mathrm{F}(4,32.6)=15.02, \mathrm{p}<0.0001)$, diagnosis, $(\mathrm{F}(2,30.2)=4.37, \mathrm{p}=0.02)$ and race $\mathrm{F}(1,30.9)=16.82, \mathrm{p}=0.0003)$, significantly explained part of the heterogeneity of the prevalence estimates of akathisia between the included studies.

As can be seen in Table 2, the estimated prevalence rates (with 95\% CI) of akathisia, ordered from low to high, are respectively $3.9 \%$ (2.4-6.3) for iloperidone, 6.8\% (5.1-9.0) for asenapine, $10 \%(7.4-13.5)$, for brexpiprazole, $12.7 \%(10.1-16.1)$ for lurasidone, and $17.2 \%$ (13.4-22.1) for cariprazine. After Tukey-adjustment for multiple testing, the prevalence rate of 
Akathisia with newly approved antipsychotics in severe mental illness patients

akathisia was significantly $(\mathrm{p}<0.05)$ lower in iloperidone compared to brexpiprazole, lurasidone, and cariprazine. In addition, the prevalence rate of akathisia was significantly $(\mathrm{p}<0.05)$ lower in asenapine compared to lurasidone and cariprazine. Finally, the prevalence rate of akathisia was significantly $(\mathrm{p}<0.05)$ lower for brexpiprazole compared to cariprazine (see Table 2). Next, with respect to diagnosis, the estimated prevalence of akathisia (with 95\% CIs) is respectively 6.6\% (5.7-7.7) in schizophrenia, 9.2\% (6.8-12.5) in bipolar mania, and $11.7 \%$ (8.2-16.8) in major depression. After Tukey adjustment for multiple comparisons, there is a significantly $(\mathrm{p}<0.05)$ difference in prevalence of akathisia between schizophrenia and major depression. Further, the prevalence rate of akathisia decreases significantly $(\mathrm{p}<0.05)$ as a function of race with the estimated prevalence rate of akathisia being lower is studies in which the proportion of Caucasians is higher. Finally, it should be noted that differences in prevalence rates of akathisia between studies could not be explained by differences in time of follow-up assessment $[\mathrm{F}(1,25.2)=0.67, \mathrm{p}=0.42]$, titration time $[\mathrm{F}(1,25.7)=1.90, \mathrm{p}=0.18]$, or dosing $[\mathrm{F}(1,38.2)=1.55, \mathrm{p}=0.22]$.

Akathisia was predominantly reported as mild to moderate and generally time-limited. Treatment discontinuation rates with the NAP were low $(<5 \%)$.

With respect to publication bias Begg and Mazumdar's rank correlation (using Kendall's tau) ( $\mathrm{z}=-0.34, \mathrm{p}=0.0007)$, as well as Egger's regression intercept were significant, $[\mathrm{t}(46)=3.82, \mathrm{p}=0.0004]$, suggesting that there is evidence for publication bias.

\subsection{Meta-Analytic Results of Odds Ratio (Placebo vs. Active) of Medication-Induced Akathisia with Newly Approved Antipsychotics}


Akathisia with newly approved antipsychotics in severe mental illness patients

Based on a meta-analysis involving 48 (placebo-controlled) studies with 7,132 unique patients in the placebo condition and 12,722 unique patients in the active medication condition, an estimated weighted OR of 2.24 [95\% CI:1.93-2.62] was found, indicating that the odds of akathisia are 2.24 times higher for patients receiving a NAP, compared to those in the placebo condition. In Figure 3, the distribution of the estimated ORs with 95\% CI for each individual study, ordered from smallest to largest, is presented together with the weighted OR for the FEM and REM. Further, the Q-statistic indicated that the distribution of the LORs of individual studies is not homogeneous $(\chi 2(47)=102.22, p<0.0001)$, implying that the variability in LORs between studies is larger than can be expected on the basis of sampling error. Therefore, we estimated a REM, assuming that the variance of the LORs of individual studies is due to subject-level sampling error and other (unknown) sources of systematic variation. As can be seen in this figure, the estimated weighted OR from the REM is 2.43 (95\% CI: 1.91-3.10), indicating that the odds of having akathisia are 2.4 times higher for patients in the active treatment condition compared to those in the placebo condition.

\section{Figure 3: Distribution of estimated odds ratios with $95 \%$ CIs of akathisia for each} individual study 


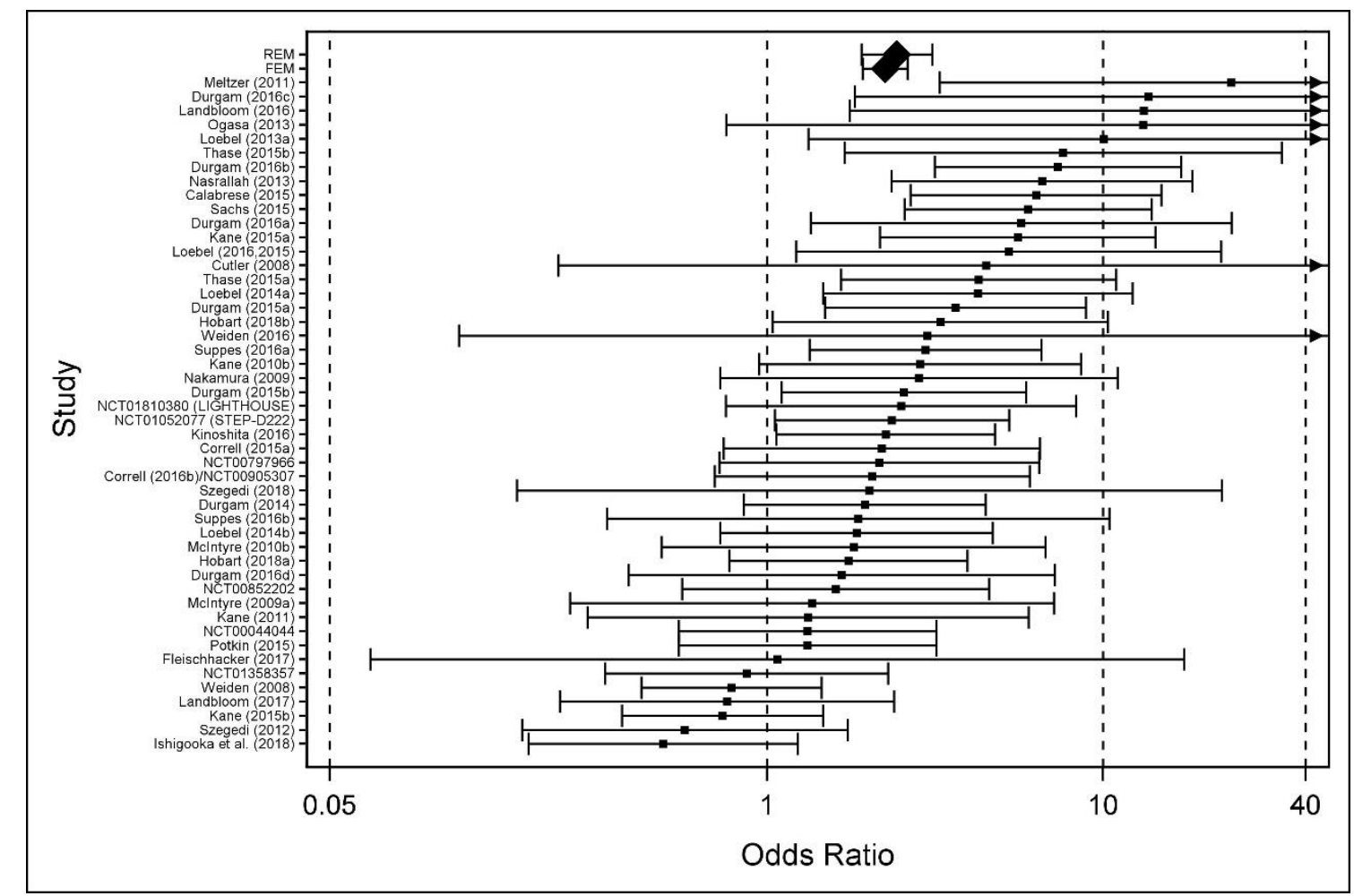

When examining the potential role of several study characteristics to explain systematic differences in the ORs for akathisia between placebo versus treatment conditions across studies, results revealed that part of this heterogeneity can be explained by medication type, $\mathrm{F}(4,24.4)=3.36, \mathrm{p}=0.03$.

The ORs for the different medication groups are shown in Table 3. Note that all ORs are significantly different from 1 with the exception of the OR for iloperidone (for which 1 is included within the $95 \%$ CI interval). However, after Tukey-adjustment for multiple testing, there were no significant $(\mathrm{p}<0.05)$ differences between these ORs. Finally, there were no effects found for diagnosis $[F(2,32.8)=0.68, p=0.52]$, time of follow-up assessment $[F(1,38)=0.04, p=0.84]$, titration time $[F(1,31.1)=0.39, p=0.54]$, dosing $[F(1,38)=0.32$, $\mathrm{p}=0.57]$ and $\operatorname{race}[\mathrm{F}(1,27)=0.09, \mathrm{p}=0.77]$. 
Table 3. Odds Ratio for akathisia comparing medication with placebo conditions

\begin{tabular}{|l|l|l|}
\hline $\begin{array}{l}\text { Newly approved } \\
\text { antipsychotic }\end{array}$ & Odds Ratio & 95\% CI \\
\hline Iloperidone & 1.20 & $0.42-3.45$ \\
\hline Brexpiprazole & 2.04 & $1.09-3.83$ \\
\hline Asenapine & 2.37 & $1.32-4.27$ \\
\hline Lurasidone & 3.74 & $2.32-6.02$ \\
\hline Cariprazine & 4.35 & $2.80-6.75$ \\
\hline
\end{tabular}

With respect to publication bias, Begg and Mazumdar's rank correlation (using Kendall's tau) was not significant $(\mathrm{z}=-0.34, \mathrm{p}=0.0007)$, whereas Egger's regression intercept was significant $[\mathrm{t}(38)=2.49, \mathrm{p}=0.02]$. In summary, these results rather suggest that there is no evidence for publication bias.

\section{Discussion}

Within the class of antipsychotics, the risk of akathisia is greater with (particularly high-potency) first-generation antipsychotics (FGA) (e.g., haloperidol and fluphenazine) than with SGA $[3,4,98]$. Prevalence rates of akathisia with FGA vary between $8 \%$ and $76 \%$ across studies $[4,8,10]$. It was commonly thought that akathisia was not a significant problem with SGA [4]. However, despite the fact that, as a group, SGA are generally reported to be more benign than FGA [11,13,98-102], the prevalence rate of akathisia with certain SGA can be quite high [4,103]. Moreover, polypharmacy with SGA can be associated with even higher prevalence rates of akathisia [100]. Nevertheless, although several reports state that the prevalence rate of akathisia with intermediate (e.g., perphenazine) and low-potency (e.g., chlorpromazine) FGA is not necessarily higher that that seen with certain SGA $[3,102,104]$, a recent overview of Cochrane reviews and meta-analyses [103] showed that none of the SGA showed a higher prevalence figure than chlorpromazine. 
Akathisia with newly approved antipsychotics in severe mental illness patients

With respect to the NAP, our first meta-analysis yielded prevalence estimates ranging from $3.9 \%$ (iloperidone) to $17.2 \%$ (cariprazine). Even after Tukey-adjustment for multiple testing, statistically significant differences $(\mathrm{p}<0.05)$ were found between prevalence rates for several of these agents, with iloperidone showing a better akathisia profile than brexpiprazole, lurasidone and cariprazine, and with asenapine being associated with a significant lower prevalence rate of akathisia than lurasidone and cariprazine. Finally, the prevalence rate of akathisia was significantly lower for brexpiprazole, compared to cariprazine. The severity of akathisia with these agents generally seems to be mild to moderate, only in a minority of cases $(<5 \%)$ leading to treatment discontinuation. Our second meta-analysis demonstrated that, in general, the propensity of NAP to cause akathisia was more than two-fold (OR 2.43, 95\% CI: 1.91-3.10) higher than placebo. However, after Turkey adjustment for multiple testing no statistically significantly differences $(\mathrm{p}<0.05)$ in terms of medication type were found between the ORs. The fact that we found significant differences in prevalence rates of akathisia between NAP (first meta-analysis) but no significant differences in ORs for akathisia under medication conditions versus placebo (second meta-analysis) may be explained by the fact that patients under placebo conditions also report akathisia which may result in less pronounced differences between NAP.

Moreover, some important remarks have to be made. The prevalence rates reported in this meta-analysis may be an underestimation of true prevalence rates. A substantial proportion of the included studies reported rates of akathisia and restlessness separately. This introduces the possibility that a proportion of the patients in the restless category actually belong to those with medication-induced akathisia, instead of those who have illness-related restlessness (due, for example, to anxiety or depression). Moreover, prevalence rates in this analysis have been based on the percentage of patients spontaneously reporting akathisia. Although the majority of the included studies used an objective instrument (in most cases the 
Akathisia with newly approved antipsychotics in severe mental illness patients

BARS) to measure the mean change from baseline to endpoint in severity of akathisia, most

of these studies relied on spontaneous reporting, rather than on scale-defined akathisia to assess prevalence rates. As the use of these objective measurements almost consistently resulted in higher rates of akathisia in studies that included such a measurement, a metaanalysis based on scale-defined akathisia rates would generate higher figures. Finally, patients included in our analysis typically were middle-aged (mean age: 40.8 years) patients who have been treated before. However, some populations not included in our analysis, such as patients with delirium or antipsychotic-naïve patients can be particularly sensitive to the development of antipsychotic-induced akathisia, even with a different pattern for the antipsychotics medications [3]. Prevalence rates found in this meta-analysis therefore must be interpreted cautiously.

Despite this, our results suggest a distribution of akathisia prevalence rates across 4 main groups: the most benign akathisia profile is represented by iloperidone and comparable to that of quetiapine, followed by asenapine and brexpiprazole, having a risk comparable to that of olanzapine (although the latter may be somewhat more benign regarding this sideeffect than brexpiprazole), and finally lurasidone and cariprazine, both comparable to the profile of risperidone. In accordance with this classification, head-to-head comparisons of older SGA and NAP have found that in patients with schizophrenia the risk of akathisia with lurasidone and cariprazine seems to be higher than with olanzapine and asenapine [105-108]. The risk of akathisia with quetiapine extended-release and iloperidone has been found to be not statistically significant different from, or even to be lower than with placebo [105]. Former analyses indicated that brexpiprazole seems to cause significant less akathisia than aripiprazole [14,109], somewhat comparable with the risk for ziprasidone [107], both having akathisia profiles that are similar to that of olanzapine [103]. 
Akathisia with newly approved antipsychotics in severe mental illness patients

Akathisia is the most common reported treatment-emergent adverse event in cariprazine-treated patients with schizophrenia $[22,54,55,60,80,97,102,110-116]$, as well as in patients with bipolar mania, depression or mixed episodes $[53,56,58,59,61,115,117,118]$ or major depressive disorder, where cariprazine is used as an adjunctive treatment [52]. However, the severity of these adverse events are generally mild to moderate $[52,53,58$ $61,102]$ and $\leq 1 \%$ of patients with schizophrenia $[22,102]$ and $<5 \%$ of patients with bipolar disorder $[53,56,59,61,119]$ overall discontinue cariprazine due to akathisia, suggesting that akathisia in patients treated with cariprazine is manageable for most of them $[60,119]$. The literature generally reports a lower rate of akathisia with cariprazine in patients with schizophrenia, compared with bipolar mania patients. This is in line with the higher prevalence rate of akathisia that has been found in our analysis for patients with bipolar mania, compared to patients with schizophrenia treated with NAP (although this difference disappeared after correction for multiple comparisons). This may be related to between-trial differences in doses (the recommended dose range for patients with schizophrenia treated with cariprazine is 1.5 to $6 \mathrm{mg}$ once daily, while this for manic or mixed episodes associated with bipolar I disorder is 3 to $6 \mathrm{mg}$ once daily), faster titration schedules applied in the bipolar mania studies, the underlying symptomatology of bipolar mania, or the greater sensitivity to antipsychotic-induced adverse events of some patients with bipolar mania or depression $[22,61,119-121]$. Most new cases of akathisia with cariprazine are reported during the first 2-6 weeks of treatment; the number of new cases decreases dramatically thereafter $[22,60,61,102,119]$.

Higher rates of akathisia are equally observed in individuals with schizophrenia receiving lurasidone, in comparison to most other SGA [122,123]. An analysis of pooled patient data from four randomized, placebo-controlled, 6-week premarketing studies of lurasidone $(20-160 \mathrm{mg} /$ day $)$ in adult patients with schizophrenia $(\mathrm{n}=1,508)$ found a percentage 
Akathisia with newly approved antipsychotics in severe mental illness patients

of $12.9 \%$ (versus $3 \%$ for placebo-treated patients) for all doses combined [122,124]. Akathisia

with lurasidone in the schizophrenia studies seems to be dose-related [17-20,122], with a percentage of $22 \%$ for lurasidone $120 \mathrm{mg} /$ day [122]. A recent meta-analysis of 8 randomized controlled short-term (6-week) trials, including 2,373 patients with acute schizophrenia, found the number needed to harm for lurasidone (20-160 mg/day) to be 11 (95\% CI: $8-17$, $\mathrm{p}<0.00001)$ [125]. The rates of akathisia reported by patients in long-term (6-months to 2 year) schizophrenia studies of lurasidone (between $10.7 \%$ and 14.3\%) are similar and consistent with those reported in short-term studies. Despite this, rates of discontinuation because of akathisia remain low (between $0.4 \%$ and $1.6 \%$ ) in lurasidone treatment groups $[92,93,126,127]$. There are indications that evening administration of lurasidone may be associated with lower rates of akathisia [91,127]. Switching from olanzapine to lurasidone seems to result in a modest increase in the incidence of akathisia $[127,128]$.

Across available (systematic) reviews, based on randomized controlled trials, akathisia is equally consistently mentioned among the most commonly reported adverse events with lurasidone in the treatment of bipolar depression, as monotherapy, or as adjunctive therapy with lithium or valproate [129-135]. In patients with bipolar depression a percentage of 9.4\% and $10.8 \%$ (all doses combined, versus $2.4 \%$ and $4.8 \%$ for placebo-treated patients) was noted in patients receiving lurasidone monotherapy or adjunctive therapy, respectively, both at daily doses ranging from 20 to $120 \mathrm{mg}[122,124]$. Among adults with bipolar I depression, lurasidone monotherapy, compared with placebo, has a $\mathrm{NNH}$ for akathisia of $15(\mathrm{NNH}=18$ for lurasidone $20-60 \mathrm{mg} / \mathrm{day}$ and $\mathrm{NNH}=12$ for lurasidone $80-120 \mathrm{mg} / \mathrm{day}$ ) $[133,136]$ and a $\mathrm{NNH}$ for akathisia of 30 (not statistically significant) as adjunctive therapy with lithium or valproate [133]. The incidence of akathisia is higher in patients with bipolar depression associated with mixed features [137]. 
Akathisia with newly approved antipsychotics in severe mental illness patients

Compared to all other currently available D2/5HT2A antagonist antipsychotics, iloperidone has the most favorable akathisia profile $[138,139]$. Studies have shown that iloperidone has a very low propensity to cause akathisia that is generally similar to or even lower than with placebo [16,32,33,105,138-140]. Our analysis also showed that iloperidone $(\mathrm{OR}=1.20,95 \% \mathrm{CI}: 0.42-3.45)$ had the lowest risk of all NAP, a risk that is comparable to placebo. This favorable akathisia profile of iloperidone is seen across the entire therapeutic dose range, and the need for anticholinergics or other anti-akathisia treatments is relatively infrequent $[16,33,141,142]$. A post-hoc analysis of pooled patient data from four Phase III, placebo- and active controlled 4- or 6-week, fixed- or flexible-dose studies, found no statistically significant association with akathisia for iloperidone at any dose [3.6\%, $\mathrm{NNH}=113$ (iloperidone 4-8 mg/day), 1.7\%, NNH=-94 (iloperidone 10-16 mg/day), 2.3\%, $\mathrm{NNH}=-236$ (iloperidone $20-24 \mathrm{mg} /$ day) vs. $2.7 \%$ (placebo)] [30,32,33,143]. The low akathisia burden is sustained during long-term treatment $[16,140]$ and the majority of patients taking iloperidone experience no change or improvement in akathisia BARS and ESRS scores [140]. Switching from antipsychotics with a higher propensity to cause akathisia (such as aripiprazole or risperidone) to iloperidone by either gradual or an immediate method can be an appropriate option for patients who experience suboptimal therapy due to the burden of akathisia, as this switch can be done without any clinically significant differences in ratings of overall efficacy [138].

Although displaying a high affinity for and antagonism at 5-HT2A receptors [144], akathisia is one of the most frequently reported adverse events with asenapine during acute treatment in adults with schizophrenia or manic or mixed episodes associated with bipolar I disorder [145-147]. This suggests that the pathophysiology of akathisia involves other than dopaminergic and serotonergic receptors and is multifactorial [106] (see further). 
Akathisia with newly approved antipsychotics in severe mental illness patients

According to an analysis of pooled patient data from four short-term placebo-controlled

premarketing trials (a pool of three 6-week fixed-dose trials and one 6-week flexible-dose trial) in adult patients with acute schizophrenia $(\mathrm{n}=572)$, akathisia (including hyperkinesia) occurs at greater incidence with treatment with sublingual asenapine 5 or $10 \mathrm{mg}$ BID (4\% and $11 \%$, respectively) than with placebo $(3 \%)(n=378)$ [148]. This effect appears to be doserelated $[145,148]$. Compared with olanzapine, asenapine is more likely to cause akathisia [106,149]. A meta-analysis focusing on akathisia in patients with schizophrenia treated with asenapine, aripiprazole or lurasidone found that asenapine had a double higher risk of akathisia than placebo or other older SGA, with double the risk of olanzapine (Relative Ratio $=2.23,95 \%$ CI 1.45-3.42) [106]. Pooled results from two randomized multicenter trials in stable patients with persistent negative symptoms in schizophrenia $(n=949)$ showed that switching to asenapine from other antipsychotic agents is associated with a higher percentage of patients reporting akathisia during the first 28 days of the switch period, compared with patients who were switched to olanzapine (3.6\% versus $1.9 \%)$ [150].

Another analysis of pooled patient data from three short-term placebo-controlled premarketing trials (a pool of two 3-week flexible-dose trials and one 3-week fixed-dose trial) in adult patients with bipolar mania $(n=620)$, showed that akathisia equally occurs at greater incidence with treatment with sublingual asenapine 5 or $10 \mathrm{mg}$ BID $(6 \%)$ than with placebo (2 $\%)$ in these patients ( $\mathrm{n}=329)$. Again, the effect appears to be dose-related [148].

\begin{abstract}
Akathisia is also one of the most commonly reported adverse events in long-term studies of asenapine in the treatment of schizophrenia [42,43,49] and bipolar disorder [37]. In a doubleblind 40-week extension study in patients with bipolar disorder, the most commonly reported extrapyramidal symptom (EPS) was akathisia, occurring in $11.4 \%$ of asenapine-treated patients and $10.3 \%$ of olanzapine patients [37]. As rates of akathisia were higher in asenapinetreated patients in this extension study, compared to the rates that have been found in the
\end{abstract}


Akathisia with newly approved antipsychotics in severe mental illness patients

initial short-term studies $[35,36,38]$, this indicates that some cases of acute akathisia with

asenapine persist for months, and thus become chronic, and tardive cases of akathisia emerged. This, however, has not been found in another extension study with schizophrenic patients, where cases of akathisia disappeared with continued use of asenapine (2.5 mg BID and $5 \mathrm{mg}$ BID) [49].

Brexpiprazole is a dopamine partial agonist antipsychotic in the same class as aripiprazole. However, with less intrinsic activity than aripiprazole at the D2 receptor, stronger antagonistic activity at serotonin 5-HT2A and noradrenergic $\alpha 1 \mathrm{~B}$ receptors, and stronger agonistic activity at serotonin 5-HT1A receptors, the pharmacological properties of brexpiprazole would suggest a more tolerable side effect profile with regard to akathisia $[70,72,76,107,109,151,152]$.

The analysis of pooled patient data from two randomized, placebo-controlled, 6-week fixeddose, premarketing studies of brexpiprazole (1-4 mg/day) in adult patients with schizophrenia $(\mathrm{n}=852)$ found a percentage of $5.2 \%$ (all doses combined) versus $4.6 \%$ for placebo-treated patients $[71,80,151,153]$. Other short-term randomized controlled (6 weeks) [71,72], as well as long-term open-label (52 weeks) extension studies confirmed this relatively favorable safety profile [70]. In long-term, open-label extension studies (brexpiprazole 1-4 mg/day, 52 weeks) akathisia rates remained low (between $4.6 \%$ and $8.5 \%$ ) [70,154,155]. In patients receiving brexpiprazole treatment during periods longer that one year, activating side effects, such as akathisia, seem to be generally resolved [69]. Thus, over time, the incidence of akathisia events may reduce with continued brexpiprazole use [76]. An overview of short (fixed and flexible dose)- and long-term safety data of brexpiprazole showed the incidence of akathisia in short-term trials was similar in the brexpiprazole $2-4 \mathrm{mg}(\mathrm{n}=822)$, pooled brexpiprazole $(<2 \mathrm{mg}->4 \mathrm{mg})(\mathrm{n}=1,256)$ and placebo groups $(5.7 \%, 5.8 \%$ vs. $4.5 \%$, respectively), although it increased profoundly with doses $>4 \mathrm{mg}$ (15.1\%) (this higher 
Akathisia with newly approved antipsychotics in severe mental illness patients

incidence, however, is seen in studies when brexpiprazole is started without titration) [70].

The onset of akathisia in schizophrenia trials mostly occurred during the first 3 weeks of treatment (peak incidence between days 8 and 11 of treatment) and is dose-related. Akathisia tends to be mild to moderate and discontinuations due to akathisia with brexpiprazole are uncommon $[\leq 1 \%$ in both short-term $(0.1 \%)$ and long-term studies $(0.4 \%-1.1 \%)]$ $[70,71,80,81,107,152,153,155,156]$. The NNH for akathisia in the short-term studies has been estimated 84 for the brexpiprazole 2-4 mg group, which is higher (and thus more promising) than these for aripiprazole $(\mathrm{NNH}=34)$, risperidone $(\mathrm{NNH}=15)$ and olanzapine $(\mathrm{NNH}=25)$ [70,112]. Adequately powered studies comparing brexpiprazole with other antipsychotics are not available. In an open-label 6-week trial comparing brexpiprazole $3 \mathrm{mg} /$ day with aripiprazole $15 \mathrm{mg} / \mathrm{day}$, the incidence of akathisia was lower in patients treated with brexpiprazole $(9.4 \%)$ than aripiprazole $(21.2 \%)$ [72].

Akathisia is nevertheless a common treatment-emergent adverse effect with brexpiprazole as an antidepressant adjunct for major depressive disorder [151,157]. For brexpiprazole NNH values for akathisia have been found to be lower (thus more problematic) for the treatment of major depressive disorder than for schizophrenia [105]. In short-term (6 weeks) placebocontrolled and long-term (52 weeks) open-label studies, reported percentages of akathisia with adjunctive brexpiprazole (1-3 mg/day for short-term studies) were $8.6 \%$ (versus $1.7 \%$ for placebo) and $10.0 \%$, respectively [78]. In premarketing, fixed-dose, clinical trials, the incidence of akathisia events for brexpiprazole (1-3 mg/day) + antidepressant- treated patients was $9 \%$ versus $2 \%$ for placebo + antidepressant-treated patients [151]. The risk of akathisia was found to be higher in the brexpiprazole group than in the placebo group, with a pooled risk ratio of $3.39(95 \%$ CI 2.08-5.51, p<0.00001) [79].

The incidence of akathisia with brexpiprazole in patients with major depressive disorder, however, remains lower than that reported in randomized studies with adjunctive aripiprazole 
Akathisia with newly approved antipsychotics in severe mental illness patients

( $24.8 \%$ versus $4.4 \%$ for placebo) $[77,78,105,158,159]$, but higher than with other

antipsychotics approved for adjunctive treatment of major depressive disorder [quetiapine extended release $(2.1 \%$ versus $1 \%$ for placebo) or the combination of olanzapine with fluoxetine (3.3\% versus $2.7 \%$ for placebo)] for treatment-resistant major depressive disorder $[78,105,158]$. The NNH for akathisia during adjunctive treatment was found to be 15 (95\% CI: 11-23) for brexpiprazole, versus 5 (95\% CI: 4-7) for aripiprazole, 91 (not statistically significant) for quetiapine extended release, and >100 (not statistically significant) for the olanzapine/fluoxetine combination $[105,158]$.

Akathisia with brexpiprazole usually occurs 2-4 weeks after treatment initiation, and appears to be dose-related, with higher incidences of akathisia for doses of more than $2 \mathrm{mg}[78,79]$. The median duration of akathisia seems to be similar across the brexpiprazole doses, ranging from 20 to 22.5 days. The majority of akathisia adverse events are assessed by the investigator as mild or moderate in severity [78].

It is known that rapid antipsychotic titration has the potential to increase the risk of akathisia. However, titration time in our analysis did not explain differences in prevalence rates of akathisia between studies. Although slow initiation of antipsychotics may be preferable when performing an antipsychotic switch, a recent meta-analysis [160] found no significant difference in akathisia rates between the slow vs. rapid initiation group for relatively stable patients with schizophrenia (Risk Ratio 0.69; 95\% CI: 0.43-1.11, $\mathrm{p}=0.13$ ). Patients included in our analysis were relatively stable, middle-aged patients with a longer disease history. These patient features therefore can explain why we didn't find a significant result for this study characteristic. Results also indicated that Caucasians may be statistically significantly $(\mathrm{p}<0.01)$ less vulnerable for medication-induced akathisia, compared to other ethnic groups. Although ethnicity has been identified as an important risk factor associated 
Akathisia with newly approved antipsychotics in severe mental illness patients

with tardive dyskinesia (with Caucasians having a lower risk) [161], the literature seems to be less clear regarding the association of akathisia with ethnicity [162].

Although the pathophysiology of akathisia is still unclear, it seems likely that a complex interplay of several neurotransmitter systems are involved in its pathophysiology. Dopaminergic and serotonergic receptor activities seem to play a major role. In addition, acetylcholine, gamma-aminobutyric acid (GABA), and noradrenergic receptor activities, as well as mechanisms related to neuro-inflammation have also been suggested to play a role in the emergence of akathisia $[2,3,4,7,106,121,163]$.

Since akathisia is predominantly induced by dopamine receptor antagonist antipsychotics, blockade of dopamine D2 receptors is believed to be an important factor in the pathophysiology of akathisia. Dopaminergic $\mathrm{D}_{2}$ receptors are particularly found in high concentration in the basal ganglia (playing a critical role in motor control) [164]. Studies have shown that EPS, including akathisia, is associated with dopamine deficiency in the basal ganglia, caused by an excessive blockade of dopamine $\mathrm{D}_{2}$ receptors (>75-80\%) [165-169]. Recently, it has been suggested that antipsychotic agents capable of blocking striatal D1 and D2 receptors might be less likely to induce EPS than those acting selectively on either D1 or D2 receptors [170]. A study, that examined the long-term effects of multiple doses of iloperidone on dopamine D1, D2, D3, and D4 receptor subtypes in rats, has found that the upregulation of striatal D1 receptors after treatment with $5 \mathrm{mg} / \mathrm{kg}$ iloperidone might offset the EPS associated with striatal D2 receptor upregulation, possibly offering one (although not the most important) explanation for the lower incidence of akathisia with iloperidone [170].

Antagonism of serotonin 5-HT2A receptors may decrease the risk of akathisia as SGA, as a group, have a lower incidence of akathisia than FGA by blocking these receptors $[106,167]$. Blockade of cortical 5-HT2A receptors may stimulate dopamine release in the striatum that 
Akathisia with newly approved antipsychotics in severe mental illness patients

partially reverses the D2 dopamine receptor blockade there (reducing the D2 receptor binding below $80 \%$ to more like $60 \%$ ), which should minimize the incidence of akathisia $[166,171]$. Therefore, it would be expected that iloperidone and asenapine would have a lower incidence of akathisia, as these agents display more potent antagonist activity at 5-HT2A than dopamine D2 receptors, compared to lurasidone, brexpiprazole and cariprazine, displaying relatively equivalent binding at both sites [172]. This serotonergic receptor activity mechanism also explains why SSRIs (having no affinity for the dopamine D2 receptor) may induce akathisia. These agents stimulate 5-HT2A receptors, which results in inhibition of dopamine release [167].

In addition to serotonin 5-HT2A receptor antagonism, observations that the use of anticholinergics, benzodiazepines and $\beta$-adrenergic blockers may alleviate symptoms of akathisia, suggest a role for other neurotransmitters as well $[3,10,121]$. Of these adrenergic receptor activity may be particular important. Indeed, the pharmacologic action that distinguishes iloperidone most from other SGA is its potent antagonism of $\alpha 1$ adrenergic receptors. Moreover, this property is the most potent of all pharmacologic actions of iloperidone. Alpha-1 adrenergic antagonism hypothetically causes downstream release of striatal dopamine [166]. Thus, the low incidence of akathisia associated with iloperidone may be linked to its unique binding profile of high affinity antagonism of both $\alpha 1$ adrenergic receptors and serotonin 5HT2A receptors, and its simultaneous antagonism of D1 and D2 receptors. Asenapine, having a low-to-moderate akathisia risk, will also very likely cause significant blockade at the $\alpha 1$ adrenergic receptors [173]. One exception to the $\alpha 1$ adrenergic hypothesis is that risperidone, which has relatively high $\alpha 1$ receptor binding, nevertheless has higher rates of akathisia [166,173].

Once developed, akathisia should prompt reassessment of treatment, with reduction in dose, discontinuation of the causative agent, or switching to a SGA with low akathisia 
potential (including iloperidone and quetiapine), all of which, however, incur the risk of psychotic exacerbation or relapse $[1,2,4,8,10]$. Therefore, the addition of an anti-akathisia agent may be necessary [2]. If the akathisia worsens during dose reduction or a medication switch, tardive akathisia may be present. The general treatment guidelines for this condition, however, follow those of acute akathisia, with the exception that, when severe, tardive akathisia can be suppressed with a reinstitution of the offending antipsychotic at the previous dose [4]. In cases of refractory akathisia, clozapine can be considered [2].

The actual evidence base for treatments of akathisia is very small, and many of the recommendations are based on clinical experience, case reports, and reports from studies of drugs where akathisia was not a primary concern [4].

$\beta$-adrenergic antagonists have been effective in some studies, although their use is limited by the risk for hypotension, bradycardia, sleep disturbances, and medical contraindications (e.g., patients with comorbid diabetes) $[2,8,10]$. Moreover, results from meta-analyses have reported that the efficacy of $\beta$-adrenergic antagonists in the treatment of akathisia is poor at best [174]. The therapeutic action of $\beta$-adrenergic antagonists is linked to their purported action in blocking noradrenergic/serotonergic input into the dopaminergic pathways [2]. The non-selective $\beta$-adrenergic antagonist propranolol (40-80 mg/day BID) should be the firstchoice option if adjunctive medication (rather than dose lowering or antipsychotic switching) is required for the treatment of akathisia, as this agent has the most robust evidence to support its use for subjective and objective symptoms of akathisia [1,2]. There are no reports of worsening psychosis associated with propranolol use [1]. However, this medication should only be given after reviewing contraindications and associated precautions (cf. supra) on a per-patient basis. Moreover, due to the short duration of studies it is difficult to decide how long propranolol, if helpful, should be continued [1]. Another adrenergic antagonist studied is metoprolol (although evidence to support its use is extremely limited) [1,2]. 
Akathisia with newly approved antipsychotics in severe mental illness patients

Anticholinergics are traditionally used to treat antipsychotic-induced EPS. The anticholinergic

medications benztropine and biperiden should not be routinely used for the treatment of medication-induced akathisia, due to the extremely limited available evidence for its use in antipsychotic-induced akathisia (with inconsistent findings among studies) and the risk of cognitive and anticholinergic adverse effects with these drugs $[1,2,175]$. Their limited efficacy also makes them relatively unsuitable for long-term use [2]. Some older data $[176,177]$ suggest that anticholinergics may be preferentially helpful in patients with akathisia and co-existing parkinsonism $[1,8,10]$. Despite the lack of controlled data supporting this approach, anticholinergics are still often recommended for this kind of patients [2].

As antipsychotics with high 5-HT2A antagonist activity relative to D2 antagonistic activity are associated with reduced risk for EPS, serotoninergic 5-HT2A antagonists, such as mianserin, mirtazapine, trazodone and cyproheptadine, have been assessed for their antiakathisic effects $[1,2,8,10]$. Once again, although findings suggest that 5-HT(2A) antagonists are effective in the treatment of medication-induced akathisia [178], evidence remains limited to support the use of 5-HT2A antagonists for the treatment of akathisia. Moreover, sedation is the most common adverse effect with mianserin and mirtazapine [1]. Only when propranolol is contraindicated, ineffective, or not tolerated and long-term pharmacological management of akathisia is anticipated, the use of a serotonin-based strategy for akathisia may be considered $[1,2]$.

Benzodiazepines, considered as second-line treatment for akathisia [2], have been useful owing to their anxiolytic and sedative properties $[8,10]$. However, long-term use of benzodiazepines should be avoided because of the risk of dependence, drowsiness (and risk of fall) and cognitive side effects. After the disappearance of akathisia clinicians should consider gradual tapering of the benzodiazepine [1,2]. 
Akathisia with newly approved antipsychotics in severe mental illness patients

The role of antihistamines remains controversial with some studies suggesting reduction in

akathisia and other studies reporting that antihistamines worsened akathisia. Moreover, antihistamines can also be associated with serious adverse events [2].

In patients failing to respond to alternative treatments for persistent antipsychotic-induced akathisia, short-term therapy with vitamin B6 may be considered. However, extremely limited evidence for its use exist and long-term use of vitamin B6 can cause an irreversible and severe neuropathy [1].

Many other medications have been assessed as potential treatments for antipsychotic-induced akathisia, including amantadine (acting as a dopamine reuptake inhibitor through it antagonism of the glutamate receptor), apomorphine, clonidine, gabapentin, and pregabalin $[1,2,10]$. Some are promising but the evidence available on the potential risks and benefits for these agents (e.g., the emergence of psychosis associated with the use of amantadine) as treatments for akathisia limits their utility in akathisia [1,2].

\section{Conclusion}

The results of our first meta-analysis showed different prevalence rates of akathisia for different NAP. These differences disappeared when prevalence rates of akathisia were compared under medication versus placebo conditions after correction for multiple comparisons. This may be due to the fact that patients under placebo condition also spontaneously report akathisia. Moreover, due to patient characteristics and methodological issues, prevalence rates with NAP may be an underestimation of true prevalence rates so that trend differences between medications in our second meta-analysis actually represent real differences. A meta-analysis based on objectives measurements, including younger and/or non-Caucasian patients with a severe mental illness other than schizophrenia, would probably 
generate even higher figures. Taken all the above into consideration, one can assume that

\section{References}

1. Pringsheim T, Gardner D, Addington D, et al. The assessment and treatment of antipsychotic-induced akathisia. Can J Psychiatry. 2018 Jan 1:706743718760288. doi: 10.1177/0706743718760288.

2. Salem H, Nagpal C, Pigott T, Teixeira AL. Revisiting antipsychotic-induced akathisia: current issues and prospective challenges. Curr Neuropharmacol. 2017;15(5):789-98.

3. Forcen FE, Matsoukas K, Alici Y. Antipsychotic-induced akathisia in delirium: a systematic review. Palliat Support Care. 2016;14(1):77-84.

4. Lohr JB, Eidt CA, Abdulrazzaq Alfaraj A, Soliman MA. The clinical challenges of akathisia. CNS Spectr. 2015;20(Suppl 1):1-14.

5. Barnes TR. The Barnes Akathisia Rating Scale--revisited. J Psychopharmacol. 2003;17(4):365-70.

6. Savitt D, Jankovic J. Tardive syndromes. J Neurol Sci. 2018;389:35-42.

7. Tachere RO, Modirrousta M. Beyond anxiety and agitation: a clinical approach to akathisia. Aust Fam Physician. 2017;46(5):296-298.

8. Caroff SN, Campbell EC. Drug-induced extrapyramidal syndromes: implications for contemporary practice. Psychiatr Clin North Am. 2016;39(3):391-411.

9. American Psychiatric Association (2013). Diagnostic and statistical manual of mental disorders. Fifth edition. Arlington, VA, American Psychiatric Association.

10. Caroff SN, Hurford I, Lybrand J, Campbell EC. Movement disorders induced by antipsychotic drugs: implications of the CATIE schizophrenia trial. Neurol Clin. 2011;29(1):127-48, viii.

11. Kane JM, Barnes TR, Correll CU, et al. Evaluation of akathisia in patients with schizophrenia, schizoaffective disorder, or bipolar I disorder: a post hoc analysis of pooled data from short- and longterm aripiprazole trials. J Psychopharmacol. 2010a;24(7):1019-29.

12. Sachdev PS. Neuroleptic-induced movement disorders: an overview. Psychiatr Clin North Am. 2005; 28(1):255-74, x.

13. Juncal-Ruiz M, Ramirez-Bonilla M, Gomez-Arnau J, et al. Incidence and risk factors of acute akathisia in 493 individuals with first episode non-affective psychosis: a 6-week randomised study of antipsychotic treatment. Psychopharmacology (Berl). 2017;234(17):2563-70.

14. Kim JH, Jin YH, Kang UG, Ahn YM, Ha KS, Kim YS. Neuroleptic-induced acute and chronic akathisia: a clinical comparison. Disord. 2005;20(12):1667-70.

15. Chouinard G, Margolese HC. Manual for the Extrapyramidal Symptom Rating Scale (ESRS). Schizophr Res. 2005;76(2-3):247-65.

16. Weiden PJ, Manning R, Wolfgang CD, et al. A randomized trial of iloperidone for prevention of relapse in schizophrenia: the REPRIEVE study. CNS Drugs. 2016;30(8):735-47. 
17. Meltzer HY, Cucchiaro J, Silva R, et al. Lurasidone in the treatment of schizophrenia: a randomized, double-blind, placebo- and olanzapine-controlled study. Am J Psychiatry. 2011;168(9):957-67.

18. Nasrallah HA, Silva R, Phillips D, et al. Lurasidone for the treatment of acutely psychotic patients with schizophrenia: a 6-week, randomized, placebo-controlled study. J Psychiatr Res. 2013;47(5):670-7.

19. Ogasa M, Kimura T, Nakamura M, Guarino J. Lurasidone in the treatment of schizophrenia: a 6-week, placebo-controlled study. Psychopharmacology (Berl). 2013;225(3):519-30.

20. Potkin SG, Kimura T, Guarino J. A 6-week, double-blind, placebo- and haloperidol-controlled, phase II study of lurasidone in patients with acute schizophrenia. Ther Adv Psychopharmacol. 2015;5(6):32231.

21. Landbloom RL, Mackle M, Wu X, et al. Asenapine: efficacy and safety of 5 and 10mg bid in a 3-week, randomized, double-blind, placebo-controlled trial in adults with a manic or mixed episode associated with bipolar I disorder. J Affect Disord. 2016;190:103-10.

22. Cutler AJ, Durgam S, Wang Y, et al. Evaluation of the long-term safety and tolerability of cariprazine in patients with schizophrenia: results from a 1-year open-label study. CNS Spectr. 2018;23(1):39-50.

23. Gbinigie II, Lasserson D. Clarithromycin-induced akathisia: a class effect of macrolides? BMJ Case Rep. 2016; 2016. pii: bcr2016217421. doi: 10.1136/bcr-2016-217421.

24. Asser A, Taba P. Psychostimulants and movement disorders. Front Neurol. 2015;6:75.

25. Riesselman A, El-Mallakh RS. Akathisia with azithromycin. Ann Pharmacother. 2015;49(5):609.

26. Dressler D. Tardive dystonic syndrome induced by the calcium-channel blocker amlodipine. J Neural Transm (Vienna). 2014;121(4):367-9.

27. Wright MT. Antiemetics, akathisia, and pregnancy. Psychosomatics. 2007;48(6):461-6.

28. Lipsey MW, Wilson DB. Practical meta-analysis. Thousand Oaks: Sage Publications; 2001.

29. Kane JM, Lauriello J, Laska E, Di Marino M, Wolfgang CD. Long-term efficacy and safety of iloperidone: results from 3 clinical trials for the treatment of schizophrenia. J Clin Psychopharmacol. 2008;28(2 Suppl 1):S29-35.

30. Cutler AJ, Kalali AH, Weiden PJ, Hamilton J, Wolfgang CD. Four-week, double-blind, placebo- and ziprasidone-controlled trial of iloperidone in patients with acute exacerbations of schizophrenia. J Clin Psychopharmacol. 2008;28(2 Suppl 1):S20-8.

31. Weiden PJ, Cutler AJ, Polymeropoulos MH, Wolfgang CD. Safety profile of iloperidone: a pooled analysis of 6-week acute-phase pivotal trials. J Clin Psychopharmacol. 2008;28(2 Suppl 1):S12-9.

32. Potkin SG, Litman RE, Torres R, Wolfgang CD. Efficacy of iloperidone in the treatment of schizophrenia: initial phase 3 studies. J Clin Psychopharmacol. 2008; 28(2 Suppl 1): S4-11.

33. Citrome L, Meng X, Hochfeld M, Stahl SM. Efficacy of iloperidone in the short-term treatment of schizophrenia: a post hoc analysis of pooled patient data from four phase III, placebo- and activecontrolled trials. Hum Psychopharmacol. 2012b;27(1):24-32.

34. Potkin SG, Preskorn S, Hochfeld M, Meng X. A thorough QTc study of 3 doses of iloperidone including metabolic inhibition via CYP2D6 and/or CYP3A4 and a comparison to quetiapine and ziprasidone. J Clin Psychopharmacol. 2013;33(1):3-10.

35. McIntyre RS, Cohen M, Zhao J, Alphs L, Macek TA, Panagides J. A 3-week, randomized, placebocontrolled trial of asenapine in the treatment of acute mania in bipolar mania and mixed states. Bipolar Disord. 2009a;11(7):673--86.

36. McIntyre RS, Cohen M, Zhao J, Alphs L, Macek TA, Panagides J. Asenapine versus olanzapine in acute mania: a double-blind extension study. Bipolar Disord. 2009b;11(8):815-26.

37. McIntyre RS, Cohen M, Zhao J, Alphs L, Macek TA, Panagides J. Asenapine for long-term treatment of bipolar disorder: a double-blind 40-week extension study. J Affect Disord. 2010a;126(3):358-65.

38. McIntyre RS, Cohen M, Zhao J, Alphs L, Macek TA, Panagides J. Asenapine in the treatment of acute mania in bipolar I disorder: a randomized, double-blind, placebo-controlled trial. J Affect Disord. 2010b;122(1-2):27-38.

39. Szegedi A, Calabrese JR, Stet L, Mackle M, Zhao J, Panagides J; Apollo Study Group. Asenapine as adjunctive treatment for acute mania associated with bipolar disorder: results of a 12-week core study and 40-week extension. J Clin Psychopharmacol. 2012;32(1):46-55.

40. Azorin JM, Sapin C, Weiller E. Effect of asenapine on manic and depressive symptoms in bipolar I patients with mixed episodes: results from post hoc analyses. J Affect Disord. 2013;145(1):62-9.

41. Kane JM, Cohen M, Zhao J, Alphs L, Panagides J. Efficacy and safety of asenapine in a placebo- and haloperidol-controlled trial in patients with acute exacerbation of schizophrenia. J Clin Psychopharmacol. 2010b;30(2):106-15. 
42. Kane JM, Mackle M, Snow-Adami L, Zhao J, Szegedi A, Panagides J. A randomized placebocontrolled trial of asenapine for the prevention of relapse of schizophrenia after long-term treatment. J Clin Psychiatry. 2011;72(3):349-55.

43. Schoemaker J, Naber D, Vrijland P, Panagides J, Emsley R. Long-term assessment of Asenapine vs. Olanzapine in patients with schizophrenia or schizoaffective disorder. Pharmacopsychiatry. 2010; 43(4):138-46.

44. Schoemaker J, Stet L, Vrijland P, Naber D, Panagides J, Emsley R. Long-term efficacy and safety of asenapine or olanzapine in patients with schizophrenia or schizoaffective disorder: an extension study. Pharmacopsychiatry. 2012;45(5):196-203.

45. Buchanan RW, Panagides J, Zhao J, et al. Asenapine versus olanzapine in people with persistent negative symptoms of schizophrenia. J Clin Psychopharmacol. 2012;32(1):36-45.

46. Berk M, Tiller JW, Zhao J, Yatham LN, Malhi GS, Weiller E. Effects of asenapine in bipolar I patients meeting proxy criteria for moderate-to-severe mixed major depressive episodes: a post hoc analysis. J Clin Psychiatry. 2015;76(6):728-34.

47. Kinoshita T, Bai YM, Kim JH, Miyake M, Oshima N. Efficacy and safety of asenapine in Asian patients with an acute exacerbation of schizophrenia: a multicentre, randomized, double-blind, 6-week, placebo-controlled study. Psychopharmacology (Berl). 2016;233(14):2663-74.

48. Landbloom R, Mackle M, Wu X, et al. Asenapine for the treatment of adults with an acute exacerbation of schizophrenia: results from a randomized, double-blind, fixed-dose, placebo-controlled trial with olanzapine as an active control. CNS Spectr. 2017;22(4):333-41.

49. Durgam S, Landbloom RP, Mackle M, Wu X, Mathews M, Nasrallah HA. Exploring the long-term safety of asenapine in adults with schizophrenia in a double-blind, fixed-dose, extension study. Neuropsychiatr Dis Treat. 2017b;13:2021-35.

50. Szegedi A, Durgam S, Mackle M, Yu SY, Wu X, Mathews M, Landbloom RP. Randomized, doubleblind, placebo-controlled trial of asenapine maintenance therapy in adults with an acute manic or mixed episode associated with bipolar i disorder. Am J Psychiatry. 2018;175(1):71-9.

51. Németh G, Laszlovszky I, Czobor P, Szalai E, Szatmári B, Harsányi J, Barabássy Á, Debelle M, Durgam S, Bitter I, Marder S, Fleischhacker WW. Cariprazine versus risperidone monotherapy for treatment of predominant negative symptoms in patients with schizophrenia: a randomised, doubleblind, controlled trial. Lancet 2017; 389(10074): 1103-1113.

52. Durgam S, Earley W, Guo H, Li D, Németh G, Laszlovszky I, Fava M, Montgomery SA. Efficacy and safety of adjunctive cariprazine in inadequate responders to antidepressants: a randomized, doubleblind, placebo-controlled study in adult patients with major depressive disorder. J Clin Psychiatry 2016b; 77(3): 371-8.

53. Durgam S, Starace A, Li D, Migliore R, Ruth A, Németh G, Laszlovszky I. The efficacy and tolerability of cariprazine in acute mania associated with bipolar I disorder: a phase II trial. Bipolar Disord 2015a; 17(1): 63-75.

54. Durgam S, Cutler AJ, Lu K, Migliore R, Ruth A, Laszlovszky I, Németh G, Meltzer HY. Cariprazine in acute exacerbation of schizophrenia: a fixed-dose, phase 3, randomized, double-blind, placebo- and active-controlled trial. J Clin Psychiatry 2015b; 76(12): e1574-82.

55. Durgam S, Starace A, Li D, Migliore R, Ruth A, Németh G, Laszlovszky I. An evaluation of the safety and efficacy of cariprazine in patients with acute exacerbation of schizophrenia: a phase II, randomized clinical trial. Schizophr Res 2014; 152(2-3): 450-7.

56. Calabrese JR, Keck PE Jr, Starace A, Lu K, Ruth A, Laszlovszky I, Németh G, Durgam S. Efficacy and safety of low- and high-dose cariprazine in acute and mixed mania associated with bipolar I disorder: a double-blind, placebo-controlled study. J Clin Psychiatry 2015; 76(3): 284-92.

57. Kane JM, Zukin S, Wang Y, Lu K, Ruth A, Nagy K, Laszlovszky I, Durgam S. Efficacy and safety of cariprazine in acute exacerbation of schizophrenia: results from an international, phase III clinical trial. J Clin Psychopharmacol 2015b; 35(4): 367-73.

58. Sachs GS, Greenberg WM, Starace A, Lu K, Ruth A, Laszlovszky I, Németh G, Durgam S. Cariprazine in the treatment of acute mania in bipolar I disorder: a double-blind, placebo-controlled, phase III trial. J Affect Disord 2015; 174: 296-302.

59. Durgam S, Earley W, Lipschitz A, Guo H, Laszlovszky I, Németh G, Vieta E, Calabrese JR, Yatham LN. An 8-week randomized, double-blind, placebo-controlled evaluation of the safety and efficacy of cariprazine in patients with bipolar I depression. Am J Psychiatry 2016a; 173(3): 271-81. 
60. Earley W, Durgam S, Lu K, Laszlovszky I, Debelle M, Kane JM. Safety and tolerability of cariprazine in patients with acute exacerbation of schizophrenia: a pooled analysis of four phase II/III randomized, double-blind, placebo-controlled studies. Int Clin Psychopharmacol 2017b; 32(6): 319-328.

61. Earley W, Durgam S, Lu K, Debelle M, Laszlovszky I, Vieta E, Yatham LN. Tolerability of cariprazine in the treatment of acute bipolar I mania: a pooled post hoc analysis of 3 phase II/III studies. J Affect Disord 2017a; 215: 205-212.

62. Lao KS, He Y, Wong IC, Besag FM, Chan EW. Tolerability and Safety Profile of Cariprazine in Treating Psychotic Disorders, Bipolar Disorder and Major Depressive Disorder: A Systematic Review with Meta-Analysis of Randomized Controlled Trials. CNS Drugs. 2016; 30(11): 1043-1054.

63. Durgam S, Earley W, Li R, Li D, Lu K, Laszlovszky I, Fleischhacker WW, Nasrallah HA. Long-term cariprazine treatment for the prevention of relapse in patients with schizophrenia: a randomized, double-blind, placebo-controlled trial. Schizophr Res. 2016d; 176(2-3): 264-271.

64. Durgam S, Litman RE, Papadakis K, Li D, Németh G, Laszlovszky I. Cariprazine in the treatment of schizophrenia: a proof-of-concept trial. Int Clin Psychopharmacol 2016c; 31(2): 61-8.

65. NCT00852202 (2010). A double-blind, placebo-controlled study of rgh-188 (cariprazine) in bipolar depression.

66. Ishigooka J, Iwashita S, Tadori Y. Efficacy and safety of brexpiprazole for the treatment of acute schizophrenia in Japan: A 6-week, randomized, double-blind, placebo-controlled study. Psychiatry Clin Neurosci. 2018; 72(9): 692-700.

67. Hobart M, Skuban A, Zhang P, Augustine C, Brewer C, Hefting N, Sanchez R, McQuade RD. A randomized, placebo-controlled study of the efficacy and safety of fixed-dose brexpiprazole $2 \mathrm{mg} / \mathrm{d}$ as adjunctive treatment of adults with major depressive disorder. J Clin Psychiatry 2018a; 79(4).

68. Hobart M, Skuban A, Zhang P, Josiassen MK, Hefting N, Augustine C, Brewer C, Sanchez R, McQuade RD. Efficacy and safety of flexibly dosed brexpiprazole for the adjunctive treatment of major depressive disorder: a randomized, active-referenced, placebo-controlled study. Curr Med Res Opin 2018b; 34(4): 633-642.

69. Fleischhacker WW, Hobart M, Ouyang J, Forbes A, Pfister S, McQuade RD, Carson WH, Sanchez R, Nyilas M, Weiller E. Efficacy and Safety of Brexpiprazole (OPC-34712) as Maintenance Treatment in Adults with Schizophrenia: a Randomized, Double-Blind, Placebo-Controlled Study. Int J Neuropsychopharmacol 2017; 20(1): 11-21.

70. Kane JM, Skuban A, Hobart M, Ouyang J, Weiller E, Weiss C, Correll CU. Overview of short- and long-term tolerability and safety of brexpiprazole in patients with schizophrenia. Schizophr Res 2016; 174(1-3): 93-98.

71. Correll CU, Skuban A, Hobart M, Ouyang J, Weiller E, Weiss C, Kane JM. Efficacy of brexpiprazole in patients with acute schizophrenia: review of three randomized, double-blind, placebo-controlled studies. Schizophr Res 2016b; 174(1-3): 82-92.

72. Citrome L, Ota A, Nagamizu K, Perry P, Weiller E, Baker RA. The effect of brexpiprazole (OPC34712) and aripiprazole in adult patients with acute schizophrenia: results from a randomized, exploratory study. Int Clin Psychopharmacol 2016; 31(4): 192-201.

73. Thase ME, Youakim JM, Skuban A, Hobart M, Zhang P, McQuade RD, Nyilas M, Carson WH, Sanchez R, Eriksson H. Adjunctive brexpiprazole 1 and $3 \mathrm{mg}$ for patients with major depressive disorder following inadequate response to antidepressants: a phase 3, randomized, double-blind study. J Clin Psychiatry 2015a; 76(9): 1232-40.

74. Thase ME, Youakim JM, Skuban A, Hobart M, Augustine C, Zhang P, McQuade RD, Carson WH, Nyilas M, Sanchez R, Eriksson H. Efficacy and safety of adjunctive brexpiprazole $2 \mathrm{mg}$ in major depressive disorder: a phase 3, randomized, placebo-controlled study in patients with inadequate response to antidepressants. J Clin Psychiatry 2015b; 76(9): 1224-31.

75. McIntyre RS, Weiller E, Zhang P, Weiss C. Brexpiprazole as adjunctive treatment of major depressive disorder with anxious distress: Results from a post-hoc analysis of two randomised controlled trials. J Affect Disord. 2016; 201:116-23.

76. Marder SR, Hakala MJ, Josiassen MK, Zhang P, Ouyang J, Weiller E, Weiss C, Hobart M. Brexpiprazole in patients with schizophrenia: overview of short- and long-term phase 3 controlled studies. Acta Neuropsychiatr 2017; 29(5): 278-290.

77. Nelson JC, Weiller E, Zhang P, Weiss C, Hobart M. Efficacy of adjunctive brexpiprazole on the core symptoms of major depressive disorder: a post hoc analysis of two pooled clinical studies. J Affect Disord 2018; 227: 103-108. 
78. Nelson JC, Zhang P, Skuban A, Hobart M, Weiss C, Weiller E, Thase ME. Overview of short-term and long-term safety of brexpiprazole in patients with major depressive disorder and inadequate response to antidepressant treatment. Current Psychiatry Reviews 2016; 12: 278-290.

79. Yoon S, Jeon SW, Ko YH, Patkar AA, Masand PS, Pae CU, Han C. Adjunctive Brexpiprazole as a Novel Effective Strategy for Treating Major Depressive Disorder: A Systematic Review and MetaAnalysis. J Clin Psychopharmacol 2017; 37(1): 46-53.

80. Kane JM, Skuban A, Ouyang J, Hobart M, Pfister S, McQuade RD, Nyilas M, Carson WH, Sanchez R, Eriksson H. A multicenter, randomized, double-blind, controlled phase 3 trial of fixed-dose brexpiprazole for the treatment of adults with acute schizophrenia. Schizophr Res 2015a; 164(1-3): 127135.

81. Correll CU, Skuban A, Ouyang J, Hobart M, Pfister S, McQuade RD, Nyilas M, Carson WH, Sanchez R, Eriksson H. Efficacy and safety of brexpiprazole for the treatment of acute schizophrenia: a 6-week randomized, double-blind, placebo-controlled trial. Am J Psychiatry 2015a; 172(9): 870-880.

82. NCT01810380 (Lighthouse trial) (2014). Interventional, randomised, double-blind, parallel-group, placebo-controlled, active-reference, flexible-dose study of brexpiprazole in patients with acute schizophrenia. ClinicalTrials.gov.

83. NCT00797966. Study of the safety and efficacy of opc-34712 as adjunctive therapy in the treatment of patients with major depressive disorder. ClinicalTrials.gov.

84. NCT01052077. Study of the safety and efficacy of opc-34712 as adjunctive therapy in the treatment of adults with major depressive disorder (STEP-D222). ClinicalTrials.gov.

85. Suppes T, Kroger H, Pikalov A, Loebel A. Lurasidone adjunctive with lithium or valproate for bipolar depression: a placebo-controlled trial utilizing prospective and retrospective enrolment cohorts. J Psychiatr Res 2016a; 78: 86-93.

86. Suppes T, Silva R, Cucchiaro J, Mao Y, Targum S, Streicher C, Pikalov A, Loebel A. Lurasidone for the treatment of major depressive disorder with mixed features: a randomized, double-blind, placebocontrolled study. Am J Psychiatry. 2016b; 173(4): 400-7.

87. Loebel A, Silva R, Goldman R, Watabe K, Cucchiaro J, Citrome L, Kane JM. Lurasidone dose escalation in early nonresponding patients with schizophrenia: a randomized, placebo-controlled study. J Clin Psychiatry 2016; 77(12): 1672-1680.

88. Loebel A, Citrome L, Correll CU, Xu J, Cucchiaro J, Kane JM. Treatment of early non-response in patients with schizophrenia: assessing the efficacy of antipsychotic dose escalation. BMC Psychiatry 2015; $15: 271$.

89. Loebel A, Cucchiaro J, Silva R, Kroger H, Hsu J, Sarma K, Sachs G. Lurasidone monotherapy in the treatment of bipolar I depression: a randomized, double-blind, placebo-controlled study. Am J Psychiatry 2014a; 171(2): 160-8.

90. Loebel A, Cucchiaro J, Silva R, Kroger H, Sarma K, Xu J, Calabrese JR. Lurasidone as adjunctive therapy with lithium or valproate for the treatment of bipolar I depression: a randomized, double-blind, placebo-controlled study. Am J Psychiatry 2014b; 171(2): 169-77.

91. Loebel A, Cucchiaro J, Sarma K, et al. Efficacy and safety of lurasidone $80 \mathrm{mg} / \mathrm{day}$ and $160 \mathrm{mg} / \mathrm{day}$ in the treatment of schizophrenia: a randomized, double-blind, placebo- and active-controlled trial. Schizophr Res 2013a; 145(1-3): 101-109.

92. Loebel A, Cucchiaro J, Xu J, Sarma K, Pikalov A, Kane JM. Effectiveness of lurasidone vs. quetiapine XR for relapse prevention in schizophrenia: a 12-month, double-blind, noninferiority study. Schizophr Res 2013b; 147(1): 95-102.

93. Citrome L, Cucchiaro J, Sarma K, Phillips D, Silva R, Tsuchiya S, Loebel A. Long-term safety and tolerability of lurasidone in schizophrenia: a 12-month, double-blind, active-controlled study. Int Clin Psychopharmacol 2012a; 27(3): 165-76.

94. Potkin SG, Ogasa M, Cucchiaro J, Loebel A. Double-blind comparison of the safety and efficacy of lurasidone and ziprasidone in clinically stable outpatients with schizophrenia or schizoaffective disorder. Schizophr Res 2011; 132(2-3): 101-7.

95. Nakamura M, Ogasa M, Guarino J, et al. Lurasidone in the treatment of acute schizophrenia: a doubleblind, placebo-controlled trial. J Clin Psychiatry 2009; 70(6): 829-836.

96. NCT01358357 (2015). A randomized, double-blind, placebo-controlled, flexible-dose, parallel-group study of lurasidone adjunctive to lithium or divalproex for the prevention of recurrence in subjects with bipolar i disorder. 
97. NCT00044044 (2003). A 6-week, double-blind, randomized, fixed-dose, parallel-group study of the efficacy and safety of three dose levels of sm-13496 compared to placebo and haloperidol in patients with schizophrenia who are experiencing an acute exacerbation of symptoms. ClinicalTrials.gov.

98. Haddad PM, Das A, Keyhani S, Chaudhry IB. Antipsychotic drugs and extrapyramidal side effects in first episode psychosis: a systematic review of head-head comparisons. J Psychopharmacol 2012; $26(5$ Suppl): $15-26$.

99. Solmi M, Murru A, Pacchiarotti I, Undurraga J, Veronese N, Fornaro M, Stubbs B, Monaco F, Vieta E, Seeman MV, Correll CU, Carvalho AF. Safety, tolerability, and risks associated with first- and secondgeneration antipsychotics: a state-of-the-art clinical review. Ther Clin Risk Manag 2017; 13: 757-777.

100.Berna F, Misdrahi D, Boyer L, Aouizerate B, Brunel L, Capdevielle D, Chereau I, Danion JM, Dorey JM, Dubertret C, Dubreucq J, Faget C, Gabayet F, Lancon C, Mallet J, Rey R, Passerieux C, Schandrin A, Schurhoff F, Tronche AM, Urbach M, Vidailhet P, Llorca PM, Fond G; FACE-SZ (FondaMental Academic Centers of Expertise for Schizophrenia) group. Akathisia: prevalence and risk factors in a community-dwelling sample of patients with schizophrenia. Results from the FACE-SZ dataset. Schizophr Res. 2015; 169(1-3): 255-261.

101.Zhang JP, Gallego JA, Robinson DG, Malhotra AK, Kane JM, Correll CU. Efficacy and safety of individual second-generation vs. first-generation antipsychotics in first-episode psychosis: a systematic review and meta-analysis. Int J Neuropsychopharmacol 2013; 16(6): 1205-18.

102.Nasrallah HA, Earley W, Cutler AJ, Wang Y, Lu K, Laszlovszky I, Németh G, Durgam S. The safety and tolerability of cariprazine in long-term treatment of schizophrenia: a post hoc pooled analysis. BMC Psychiatry 2017; 17(1): 305.

103. Martino D, Karnik V, Osland S, Barnes TRE, Pringsheim TM. Movement Disorders Associated With Antipsychotic Medication in People With Schizophrenia: An Overview of Cochrane Reviews and Meta-Analysis. Can J Psychiatry. 2018 Jan 1:706743718777392.

104.Lieberman JA, Stroup TS, McEvoy JP, Swartz MS, Rosenheck RA, Perkins DO, Keefe RS, Davis SM, Davis CE, Lebowitz BD, Severe J, Hsiao JK; Clinical Antipsychotic Trials of Intervention Effectiveness (CATIE) Investigators. Effectiveness of antipsychotic drugs in patients with chronic schizophrenia. N Engl J Med 2005; 353(12): 1209-23.

105.Citrome L. Activating and sedating adverse effects of second-generation antipsychotics in the treatment of schizophrenia and major depressive disorder: absolute risk increase and number needed to harm. $\mathbf{J}$ Clin Psychopharmacol 2017; 37(2): 138-147.

106. Thomas JE, Caballero J, Harrington CA. The Incidence of Akathisia in the Treatment of Schizophrenia with Aripiprazole, Asenapine and Lurasidone: A Meta-Analysis. Curr Neuropharmacol 2015; 13(5): 681-91.

107.Parikh NB, Robinson DM, Clayton AH. Clinical role of brexpiprazole in depression and schizophrenia. Ther Clin Risk Manag 2017; 13: 299-306.

108.Rummel-Kluge C, Komossa K, Schwarz S, Hunger H, Schmid F, Kissling W, Davis JM, Leucht S. Second-generation antipsychotic drugs and extrapyramidal side effects: a systematic review and metaanalysis of head-to-head comparisons. Schizophr Bull. 2012; 38(1): 167-77.

109.Hope J, Castle D, Keks NA. Brexpiprazole: a new leaf on the partial dopamine agonist branch. Australas Psychiatry 2018; 26(1): 92-94.

110.Citrome L. Cariprazine in schizophrenia: clinical efficacy, tolerability, and place in therapy. Adv Ther 2013a; 30(2): 114-26.

111.Citrome L. Cariprazine: chemistry, pharmacodynamics, pharmacokinetics, and metabolism, clinical efficacy, safety, and tolerability. Expert Opin Drug Metab Toxicol 2013b; 9(2): 193-206.

112. Citrome L. A review of the pharmacology, efficacy and tolerability of recently approved and upcoming oral antipsychotics: an evidence-based medicine approach. CNS Drugs 2013c; 27(11): 879-911.

113.George M, Amrutheshwar R, Rajkumar RP, Kattimani S, Dkhar SA. Newer antipsychotics and upcoming molecules for schizophrenia. Eur J Clin Pharmacol 2013; 69(8): 1497-509.

114.Durgam S, Greenberg WM, Li D, Lu K, Laszlovszky I, Nemeth G, Migliore R, Volk S. Safety and tolerability of cariprazine in the long-term treatment of schizophrenia: results from a 48-week, singlearm, open-label extension study. Psychopharmacology (Berl) 2017a; 234(2): 199-209.

115.Scarff JR. Cariprazine for Schizophrenia and Bipolar Disorder. Innov Clin Neurosci 2016b; 13(9-10): 49-52.

116.VRAYLAR® (cariprazine) capsules, for oral use. Highlights of prescribing information. Revised $11 / 2017$. 
117. Caccia S, Invernizzi RW, Nobili A, Pasina L. A new generation of antipsychotics: pharmacology and clinical utility of cariprazine in schizophrenia. Ther Clin Risk Manag 2013; 9: 319-28.

118. Findlay LJ, El-Mallakh PL, El-Mallakh RS. Cariprazine for the Treatment of Bipolar Disorder. Perspect Psychiatr Care 2017; 53(3): 148-155.

119.Ketter TA, Sachs GS, Durgam S, Lu K, Starace A, Laszlovszky I, Németh G. The safety and tolerability of cariprazine in patients with manic or mixed episodes associated with bipolar I disorder: a 16-week open-label study. J Affect Disord 2018; 225: 350-356.

120.Gao K, Kemp DE, Ganocy SJ, Gajwani P, Xia G, Calabrese JR. Antipsychotic-induced extrapyramidal side effects in bipolar disorder and schizophrenia: a systematic review. J Clin Psychopharmacol. 2008; 28(2): 203-9.

121.Kane JM, Fleischhacker WW, Hansen L, Perlis R, Pikalov A 3rd, Assunção-Talbott S. Akathisia: an updated review focusing on second-generation antipsychotics. J Clin Psychiatry 2009a; 70(5): 627-43.

122.LATUDA® (Lurasidone $\mathrm{HCl}$ tablets). Highlights of prescribing information. Revised 3/2018.

123.Jaeschke RR, Sowa-Kućma M, Pańczyszyn-Trzewik P, Misztak P, Styczeń K, Datka W. Lurasidone: The 2016 update on the pharmacology, efficacy and safety profile. Pharmacol Rep 2016; 68(4): 748-55.

124. Nasrallah HA, Cucchiaro JB, Mao Y, Pikalov AA, Loebel AD. Lurasidone for the treatment of depressive symptoms in schizophrenia: analysis of 4 pooled, 6-week, placebo-controlled studies. CNS Spectr 2015; 20(2): 140-7.

125.Zheng W, Cai DB, Yang XH, Li L, Zhang QE, Ng CH, Ungvari GS, Li XB, Ning YP, Xiang YT. Short-term efficacy and tolerability of lurasidone in the treatment of acute schizophrenia: A metaanalysis of randomized controlled trials. J Psychiatr Res 2018; 103: 244-251.

126. Correll CU, Cucchiaro J, Silva R, Hsu J, Pikalov A, Loebel A. Long-term safety and effectiveness of lurasidone in schizophrenia: a 22-month, open-label extension study. CNS Spectr 2016a; 21(5): 393 402.

127.Stahl SM, Cucchiaro J, Simonelli D, Hsu J, Pikalov A, Loebel A. Effectiveness of lurasidone for patients with schizophrenia following 6 weeks of acute treatment with lurasidone, olanzapine, or placebo: a 6-month, open-label, extension study. J Clin Psychiatry 2013; 74(5): 507-15.

128. McEvoy JP, Citrome L, Hernandez D, Cucchiaro J, Hsu J, Pikalov A, Loebel A. Effectiveness of lurasidone in patients with schizophrenia or schizoaffective disorder switched from other antipsychotics: a randomized, 6-week, open-label study. J Clin Psychiatry 2013; 74(2): 170-9.

129. Fornaro M, De Berardis D, Perna G, Solmi M, Veronese N, Orsolini L, Buonaguro EF, Iasevoli F, Köhler CA, Carvalho AF, de Bartolomeis A. Lurasidone in the Treatment of Bipolar Depression: Systematic Review of Systematic Reviews. Biomed Res Int 2017; 2017: 3084859.

130.Findlay LJ, El-Mallakh P, El-Mallakh RS. Management of bipolar I depression: clinical utility of lurasidone. Ther Clin Risk Manag 2015; 11: 75-81.

131.Sanford M, Dhillon S. Lurasidone: a review of its use in adult patients with bipolar I depression. CNS Drugs 2015; 29(3): 253-63.

132.Bawa R, Scarff JR. Lurasidone: a new treatment option for bipolar depression-a review. Innov Clin Neurosci 2015; 12(1-2): 21-3.

133. Citrome L, Ketter TA, Cucchiaro J, Loebel A. Clinical assessment of lurasidone benefit and risk in the treatment of bipolar I depression using number needed to treat, number needed to harm, and likelihood to be helped or harmed. J Affect Disord 2014; 155: 20-7.

134. McIntyre RS, Cha DS, Kim RD, Mansur RB. A review of FDA-approved treatment options in bipolar depression. CNS Spectr 2013; 18 Suppl 1: 4-20.

135. Woo YS, Wang HR, Bahk WM. Lurasidone as a potential therapy for bipolar disorder. Neuropsychiatr Dis Treat 2013; 9: 1521-9.

136. Ketter TA, Miller S, Dell'Osso B, Calabrese JR, Frye MA, Citrome L. Balancing benefits and harms of treatments for acute bipolar depression. J Affect Disord 2014; 169 (Suppl 1): S24-33.

137.McIntyre RS, Cucchiaro J, Pikalov A, Kroger H, Loebel A. Lurasidone in the treatment of bipolar depression with mixed (subsyndromal hypomanic) features: post hoc analysis of a randomized placebocontrolled trial. J Clin Psychiatry 2015b; 76(4): 398-405.

138. Weiden PJ, Citrome L, Alva G, Brams M, Glick ID, Jackson R, Mattingly G, Kianifard F, Meng X, Pestreich L, Hochfeld M, Winseck A. A trial evaluating gradual- or immediate-switch strategies from risperidone, olanzapine, or aripiprazole to iloperidone in patients with schizophrenia. Schizophr Res 2014; 153(1-3): 160-8. 
139. Tonin FS, Wiens A, Fernandez-Llimos F, Pontarolo R. Iloperidone in the treatment of schizophrenia: an evidence-based review of its place in therapy. Core Evid 2016; 11: 49-61.

140.Cutler AJ, Kalali AH, Mattingly GW, Kunovac J, Meng X. Long-term safety and tolerability of iloperidone: results from a 25-week, open-label extension trial. CNS Spectr 2013; 18(1): 43-54.

141. Weiden PJ. Iloperidone for the treatment of schizophrenia: an updated clinical review. Clin Schizophr Relat Psychoses 2012; 6(1): 34-44.

142.Citrome L. Iloperidone: a clinical overview. J Clin Psychiatry 2011; 72(Suppl 1): 19-23.

143.FANAPT® (Iloperidone). Highlights of prescribing information. Revised 2/2017.

144.McIntyre RS. Asenapine: a review of acute and extension phase data in bipolar disorder. CNS Neurosci Ther 2011; 17(6): 645-8.

145.Plosker GL, Deeks ED. Asenapine: A Review in Schizophrenia. CNS Drugs 2016; 30(7): 655-66.

146.Scheidemantel T, Korobkova I, Rej S, Sajatovic M. Asenapine for bipolar disorder. Neuropsychiatr Dis Treat 2015; 11: 3007-17.

147.McIntyre R, Landbloom R, Mackle M, Wu X, Kelly L, Snow-Adami L, Mathews M, Hundt C. Efficacy and safety of asenapine $5 \mathrm{mg}$ bid and $10 \mathrm{mg}$ bid in adults with a manic or mixed episode associated with bipolar I disorder. Bipolar Disord 2015a; 17(Suppl 1): 92.

148.SAPHRIS (asenapine) sublingual tablets. Highlights of prescribing information. Revised 02/2017.

149.Pompili M, Venturini P, Innamorati M, Serafini G, Telesforo L, Lester D, Tatarelli R, Girardi P. The role of asenapine in the treatment of manic or mixed states associated with bipolar I disorder. Neuropsychiatr Dis Treat 2011; 7: 259-65.

150.Cazorla P, Mackle M, Zhao J, Ha X, Szegedi A. Safety and tolerability of switching to asenapine from other antipsychotic agents: pooled results from two randomized multicenter trials in stable patients with persistent negative symptoms in schizophrenia. Neuropsychiatr Dis Treat 2012; 8: 247-57.

151.REXULTI® (Brexpiprazole tablets). Highlights of prescribing information. Revised 2/2018.

152.Scarff JR. Brexpiprazole: A New Treatment Option for Schizophrenia. Innov Clin Neurosci 2016a; 13(7-8): 26-9.

153. Correll CU, Skuban A, Ouyang J, Weiss C, Weiller E, Kane JM. Efficacy and safety of brexpiprazole (OPC-34712) in acute schizophrenia: a pooled analysis of two pivotal studies. Eur Neuropsychopharmacol 2015b; 25(Suppl 2): S522-S523.

154.Forbes A, Hobart M, Ouyang J, Shi L, Pfister S, Hakala M. A Long-Term, Open-Label Study to Evaluate the Safety and Tolerability of Brexpiprazole as Maintenance Treatment in Adults with Schizophrenia. Int J Neuropsychopharmacol 2018; 21(5): 433-441.

155.Ishigooka J, Iwashita S, Tadori Y. Long-term safety and effectiveness of brexpiprazole in Japanese patients with schizophrenia: A 52-week, open-label study. Psychiatry Clin Neurosci 2018; 72(6): 445453.

156.Das S, Barnwal P, Winston A B, Mondal S, Saha I. Brexpiprazole: so far so good. Ther Adv Psychopharmacol 2016; 6(1): 39-54.

157.Markovic M, Gallipani A, Patel KH, Maroney M. Brexpiprazole. Ann Pharmacother 2017; 51(4): 315 322.

158. Citrome L. Adjunctive aripiprazole, olanzapine, or quetiapine for major depressive disorder: an analysis of number needed to treat, number needed to harm, and likelihood to be helped or harmed. Postgrad Med 2010; 122(4): 39-48.

159. Thase ME, Jonas A, Khan A, Bowden CL, Wu X, McQuade RD, Carson WH, Marcus RN, Owen R. Aripiprazole monotherapy in nonpsychotic bipolar I depression: results of 2 randomized, placebocontrolled studies. J Clin Psychopharmacol 2008; 28(1): 13-20.

160. Takeuchi H, Thiyanavadivel S, Agid O, Remington G. Rapid vs. slow antipsychotic initiation in schizophrenia: A systematic review and meta-analysis. Schizophr Res. 2018; 193: 29-36.

161. Stegmayer K, Walther S, van Harten P. Tardive Dyskinesia Associated with Atypical Antipsychotics: Prevalence, Mechanisms and Management Strategies. CNS Drugs. 2018; 32(2): 135-147.

162. Ormerod S, McDowell SE, Coleman JJ, Ferner RE. Ethnic differences in the risks of adverse reactions to drugs used in the treatment of psychoses and depression: a systematic review and meta-analysis. Drug Saf. 2008; 31(7): 597-607.

163.Zawar I, Caro MA, Feldman L, Jimenez XF. Acute movement disorders in the medical setting. Int J Psychiatry Med. 2016;51(5):395-413.

164.Hurd YL, Suzuki M, Sedvall GC. D1 and D2 dopamine receptor mRNA expression in whole hemisphere sections of the human brain. J Chem Neuroanat. 2001; 22(1-2): 127-37. 
165.Galdikas FJ, Marwaha R (2018). Akathisia. StatPearls [Internet]. Treasure Island (FL): StatPearls Publishing; 2018 Jan-.2018 Aug 20.

166. Stahl SM. Role of $\alpha 1$ adrenergic antagonism in the mechanism of action of iloperidone: reducing extrapyramidal symptoms. CNS Spectr. 2013;18(6):285-8.

167.Stahl SM, Lonnen AJ. The mechanism of drug-induced akathisia. CNS Spectr. 2011 Jan 15. pii: Stahl.

168.Corripio I, Ferreira A, Portella MJ, Pérez V, Escartí MJ, Del Valle Camacho M, Sauras RB, Alonso A, Grasa EM, Carrió I, Catafau AM, Alvarez E. The role of striatal dopamine D2 receptors in the occurrence of extrapyramidal side effects: iodine-123-iodobenzamide single photon emission computed tomography study. Psychiatry Res. 2012; 201(1): 73-7.

169.Lako IM, van den Heuvel ER, Knegtering H, Bruggeman R, Taxis K. Estimating dopamine $D_{2}$ receptor occupancy for doses of 8 antipsychotics: a meta-analysis. J Clin Psychopharmacol. 2013; 33(5): 675-81.

170.Choi YK, Tarazi FI. Long-Term Effects of Iloperidone on Cerebral Serotonin and Adrenoceptor Subtypes J Mol Neurosci. 2018;66(1):59-67.

171. Kee Choi Y, Tarazi FI. Long-term effects of iloperidone on cerebral dopamine receptor subtypes. Synapse. 2018 Jun 23:e22039.

172.Saklad SR. Graphic representation of pharmacology: Development of an alternative model. Ment Health Clin. 2018;7(5):201-206.

173. Richelson E. New antipsychotic drugs: how do their receptor-binding profiles compare? J Clin Psychiatry. 2010;71(9):1243-4.

174.Lima AR, Bacalcthuk J, Barnes TR, Soares-Weiser K. Central action beta-blockers versus placebo for neuroleptic-induced acute akathisia. Cochrane Database Syst Rev 2004; (4): CD001946.

175.Rathbone J, Soares-Weiser K. Anticholinergics for neuroleptic-induced acute akathisia. Cochrane Database Syst Rev 2006; (4): rathCD003727.

176. Braude WM, Barnes TR, Gore SM. Clinical characteristics of akathisia. A systematic investigation of acute psychiatric inpatient admissions. Br J Psychiatry 1983; 143: 139-150.

177. Miller CH, Fleischhacker WW. Managing antipsychotic-induced acute and chronic akathisia. Drug Saf. 2000; 22(1): 73-81.

178.Laoutidis ZG, Luckhaus C. 5-HT2A receptor antagonists for the treatment of neuroleptic-induced akathisia: a systematic review and meta-analysis. Int J Neuropsychopharmacol 2014; 17(5): 823-32. 

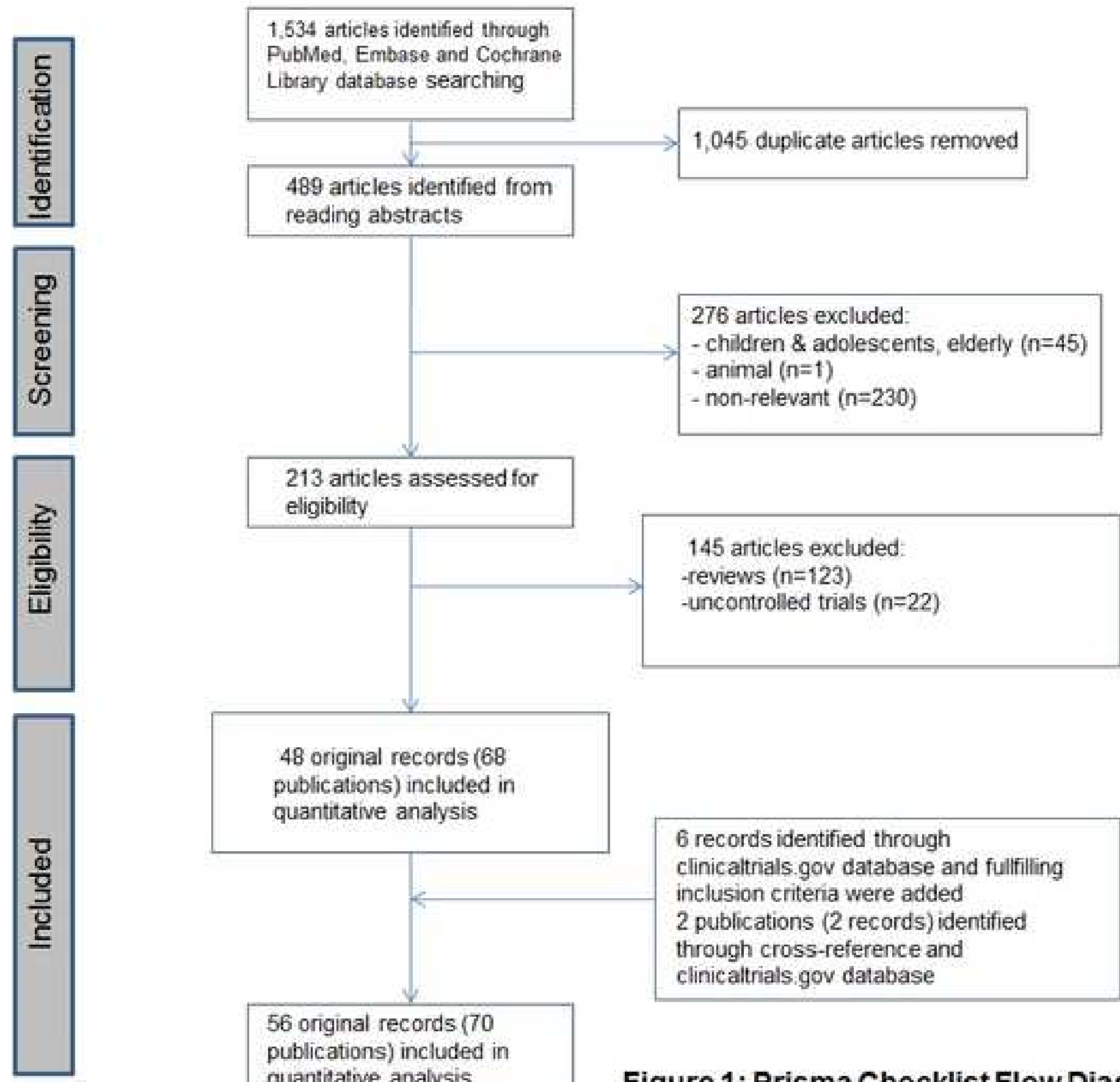

56 original records $(70$ publications) included in quantitative analysis

reviews ( $n=123$ )

clinicaltrials.gov database and fullfilling

inclusion criteria were added

through cross-reference and

clinicaltrials gov database
Fis 







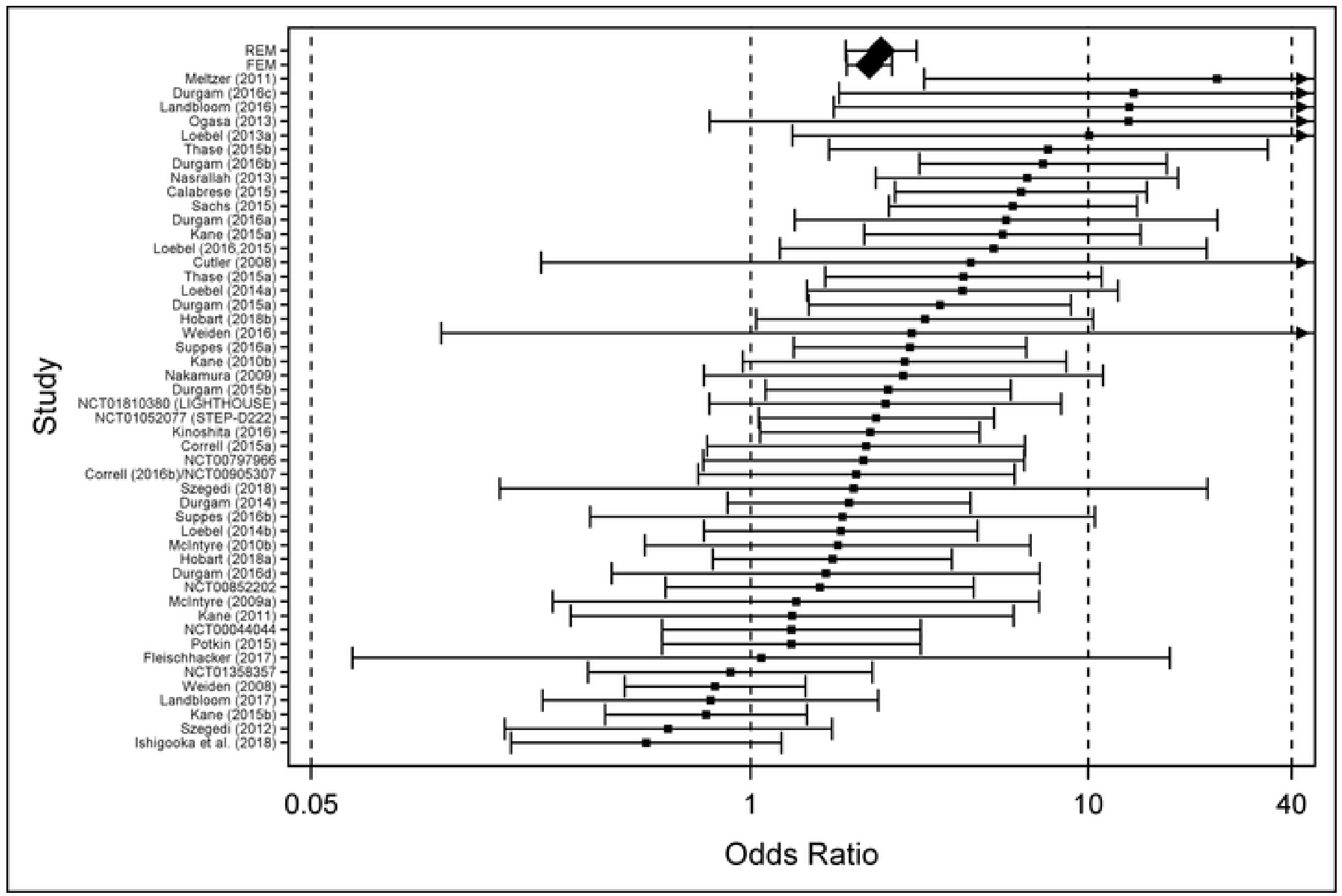




\section{Supplementary material: Characteristics of studies with newly approved antipsychotics included in the meta-analysis}

\begin{tabular}{|c|c|c|c|c|c|c|}
\hline $\begin{array}{l}\text { Newly Approved } \\
\text { Antipsychotic }\end{array}$ & Study characteristics & Prevalence of akathisia & $\begin{array}{l}\text { Mean/media } \\
\text { n time to } \\
\text { onset }\end{array}$ & $\begin{array}{c}\text { Median/ } \\
\text { median } \\
\text { duration }\end{array}$ & $\begin{array}{c}\text { Severity of } \\
\text { akathisia in most } \\
\text { cases }\end{array}$ & $\begin{array}{l}\text { Discontinuation } \\
\text { rate due to } \\
\text { akathisia }\end{array}$ \\
\hline \multicolumn{7}{|l|}{ ILOPERIDONE } \\
\hline $\begin{array}{l}\text { Weiden et al. (2016) } \\
\text { NCT01291511 }\end{array}$ & $\begin{array}{l}\text { RCT with PBO (26w) } \\
\text { Patients with SZ ( } \mathrm{n}=301) \\
\text { ILO 4-12 mg BID (after 24w stabilization on ILO 4-12 } \\
\text { BID) }\end{array}$ & $1 \%$ (ILO 4-12 mg BID, n=1/151), 0\% (PBO, n=0/150) & $\mathrm{NR}$ & NR & NR & NR \\
\hline Potkin et al. (2013) & $\begin{array}{l}\text { RCT with active control }(4 \mathrm{w}) \\
\text { Patients with SZ or SZA }(\mathrm{n}=188) \\
\text { ILO } 16-24 \mathrm{mg} / \mathrm{d} \\
\text { QUE } 375 \mathrm{mg} \text { BID } \\
\text { ZIPRA } 80 \mathrm{mg} \text { BID }\end{array}$ & $\begin{array}{l}\text { 6\% (ILO } 8 \mathrm{mg} \text { BID), } 11 \% \text { (ILO } 12 \mathrm{mg} \text { BID), 6\% (ILO } 24 \\
\text { mg QD), } 12 \% \text { (ZIPRA } 80 \mathrm{mg} \text { BID), 3\% (QUE } 375 \mathrm{mg} \\
\text { BID) }\end{array}$ & NR & NR & NR & NR \\
\hline $\begin{array}{l}\text { Weiden et al. (2008) } \\
\text { Potkin et al. (2008) } \\
\text { ILP3000ST } \\
\text { ILP3004ST } \\
\text { ILP3005ST }\end{array}$ & $\begin{array}{l}\text { Pooled analysis of } 3 \text { Phase III RCT with PBO and active } \\
\text { control }(6 \mathrm{w}) \\
\text { Acute or subacute exacerbation of SZ or SZA }(\mathrm{n}=1,943) \\
\text { ILO } 4-24 \mathrm{mg} / \mathrm{d} \\
\text { RIS } 4-8 \mathrm{mg} / \mathrm{d} \\
\text { HAL } 15 \mathrm{mg} / \mathrm{d}\end{array}$ & $\begin{array}{l}3.7 \%(\mathrm{ILO} 4-8 \mathrm{mg} / \mathrm{d}, \mathrm{n}=463), 1.5 \% \text { (ILO } 10-16 \mathrm{mg} / \mathrm{d} \\
\mathrm{n}=456), 4.8 \%(\mathrm{ILO} 20-24 \mathrm{mg} / \mathrm{d}, \mathrm{n}=125), 13.6 \% \text { (HAL } 15 \\
\mathrm{mg} / \mathrm{d}, \mathrm{n}=118), 6.9 \%(\text { RIS } 4-8 \mathrm{mg} / \mathrm{d}, \mathrm{n}=306) \text { vs. } 3.6 \% \\
(\mathrm{PBO}, \mathrm{n}=440)\end{array}$ & NR & NR & NR & NR \\
\hline $\begin{array}{l}\text { Cutler et al. (2008) } \\
\text { VP-VYY-683-3101 }\end{array}$ & $\begin{array}{l}\text { RCT with PBO and active control (Phase III) (4w) } \\
\text { Acute exacerbation of SZ (n=593) } \\
\text { ILO } 24 \mathrm{mg} / \mathrm{d} \\
\text { ZIPRA } 160 \mathrm{mg} / \mathrm{d}\end{array}$ & $\begin{array}{l}1 \%(\text { ILO } 24 \mathrm{mg} / \mathrm{d}, \mathrm{n}=1 / 300), 7 \%(\text { ZIPRA } 160 \mathrm{mg} / \mathrm{d} \text {, } \\
\mathrm{n}=11 / 150) \text { vs. } 0 \% \text { PBO }(\mathrm{n}=0 / 147)\end{array}$ & NR & NR & mild to moderate & NR \\
\hline Kane et al. (2008) & $\begin{array}{l}\text { Pooled analysis of } 3 \text { RCT }(6 \mathrm{w}) \\
\text { Patients with SZ or SZA }(\mathrm{n}=1,634) \\
\text { ILO } 4-16 \mathrm{mg} / \mathrm{d}(\mathrm{n}=1,231) \\
\text { HAL } 5-20 \mathrm{mg} / \mathrm{d}(\mathrm{n}=403)\end{array}$ & $\begin{array}{l}3.5 \%(\text { ILO } 4-16 \mathrm{mg} / \mathrm{d}, \mathrm{n}=43 / 1231), 18.6 \% \text { (HAL 5-20 } \\
\mathrm{mg} / \mathrm{d}, \mathrm{n}=75 / 403)\end{array}$ & $\mathrm{NR}$ & NR & NR & $\mathrm{NR}$ \\
\hline \multicolumn{7}{|l|}{ ASENAPINE } \\
\hline $\begin{array}{l}\text { Szegedi et al. (2018) } \\
\text { NCT01396291 }\end{array}$ & $\begin{array}{l}\text { RCT with PBO (26w) (following a 12- to } 16 \text { week open- } \\
\text { label period with flexible doses) } \\
\text { Acute manic or mixed episodes BP-I }(\mathrm{n}=253) \\
\text { ASE } 10-20 \mathrm{mg} / \mathrm{d}\end{array}$ & $\begin{array}{l}\text { 1.6\% (ASE } 10-20 \mathrm{mg} / \mathrm{d}, \mathrm{n}=2 / 126) \text { vs. } 0.8 \%(\mathrm{PBO} \text {, } \\
\mathrm{n}=1 / 126)\end{array}$ & NR & NR & NR & NR \\
\hline $\begin{array}{l}\text { Landbloom et al. } \\
\text { (2017) } \\
\text { NCT01617187 }\end{array}$ & $\begin{array}{l}\text { RCT with PBO and active control }(6 \mathrm{w}) \\
\text { Acute exacerbation of SZ }(\mathrm{n}=311) \\
\text { ASE } 2.5-5 \mathrm{mg} \text { BID } \\
\text { OLZ } 15 \mathrm{mg} / \mathrm{d}\end{array}$ & $\begin{array}{l}\text { No statistically significant differences between ASE } \\
\text { groups and PBO or OLZ and PBO: } 3.1 \% \text { (ASE } 2.5 \mathrm{mg} \\
\text { BID, } \mathrm{n}=3 / 97), 4.4 \% \text { (ASE } 5 \mathrm{mg} \text { BID, } \mathrm{n}=5 / 113), 2.2 \% \\
\text { (OLZ } 15 \mathrm{mg} / \mathrm{d}, \mathrm{n}=1 / 46) \text { vs. } 5 \% \text { (PBO) }(\mathrm{n}=5 / 101) \\
\text { BARS: } 1.1 \% \text { (ASE } 2.5 \mathrm{mg} \text { BID, } \mathrm{n}=1 / 94), 2.7 \% \text { (ASE } 5 \\
\mathrm{mg} \text { BID, } \mathrm{n}=3 / 113), 2.4 \% \text { (OLZ } 15 \mathrm{mg} / \mathrm{d}, \mathrm{n}=1 / 42) \text { vs. } \\
3.1 \%(\mathrm{PBO}, \mathrm{n}=3 / 98)\end{array}$ & NR & $\mathrm{NR}$ & mild to moderate & $\mathrm{NR}$ \\
\hline $\begin{array}{l}\text { Landbloom et al. } \\
\text { (2016) } \\
\text { NCT00764478 }\end{array}$ & $\begin{array}{l}\text { RCT with PBO (Phase IIIb) (3w) } \\
\text { Acute manic or mixed episodes BP-I }(\mathrm{n}=367) \\
\text { ASE 5-10 mg BID }\end{array}$ & $\begin{array}{l}4.1 \% \text { (ASE } 5 \mathrm{mg} \text { BID, } \mathrm{n}=5 / 122 \text { ), } 15.1 \% \text { (ASE } 10 \mathrm{mg} \\
\text { BID, } \mathrm{n}=18 / 119 \text { ) vs. } 0.8 \% \text { (PBO, } \mathrm{n}=1 / 126 \text { ) } \\
\text { There was a higher percentage of patients with a BARS } \\
\text { global score } \geq 2 \text { in both ASE groups compared with }\end{array}$ & NR & NR & mild to moderate & NR \\
\hline
\end{tabular}




\begin{tabular}{|c|c|c|c|c|c|c|}
\hline & & $\mathrm{PBO}$ & & & & \\
\hline $\begin{array}{l}\text { Kinoshita et al. } \\
(2016) \\
\text { NCT01098110 }\end{array}$ & $\begin{array}{l}\text { RCT with PBO }(6 \mathrm{w}) \\
\text { Patients with acute exacerbation of } \mathrm{SZ}(\mathrm{n}=530) \\
\text { ASE 5-10 mg BID }\end{array}$ & $\begin{array}{l}\text { 11.4\% (ASE } 5 \mathrm{mg} \text { BID, } \mathrm{n}=20 / 175), 10.5 \% \text { (ASE } 10 \mathrm{mg} \\
\text { BID, } \mathrm{n}=19 / 181) \text {, vs. PBO }(5.2 \%, \mathrm{n}=9 / 174)\end{array}$ & NR & NR & NR & NR \\
\hline $\begin{array}{l}\text { Buchanan et al. } \\
\text { (2012) }\end{array}$ & $\begin{array}{l}\text { RCT with active control }(\mathrm{n}=949) \\
\text { Eastern }[\mathrm{EH}](\mathrm{n}=481) \text { and Western Hemisphere }[\mathrm{WH}] \\
(\mathrm{n}=468) \text { study } \\
\text { Patients with persistent negative symptoms of } \mathrm{SZ}(2 \mathrm{w}) \\
\text { ASE } 10-20 \mathrm{mg} / \mathrm{d} \\
\text { OLZ } 5-20 \mathrm{mg} / \mathrm{d}\end{array}$ & $\begin{array}{l}4.5 \%(\text { ASE } 10-20 \mathrm{mg} / \mathrm{d}) \text { vs. } 1.2 \%(\mathrm{OLZ} 5-20 \mathrm{mg} / \mathrm{d})[\mathrm{EH}] \\
\text { study }\end{array}$ & NR & NR & mild to moderate & $0 \%$ \\
\hline Szegedi et al. (2012) & $\begin{array}{l}\text { RCT with PBO }(12 \mathrm{w}) \\
\text { Acute manic or mixed episodes BP-I }(\mathrm{n}=324) \\
\text { ASE } 5-10 \mathrm{mg} \text { BID }\end{array}$ & $\begin{array}{l}3.2 \%(\mathrm{ASE} 5-10 \mathrm{mg} \mathrm{BID}, \mathrm{n}=5 / 158) \text { vs. } 5.4 \%(\mathrm{PBO} \text {, } \\
\mathrm{n}=9 / 166)\end{array}$ & NR & NR & NR & NR \\
\hline $\begin{array}{l}\text { Schoemaker et al. } \\
\text { (2010) } \\
\text { NCT00212784 } \\
\end{array}$ & $\begin{array}{l}\text { RCT with active control }(52 \mathrm{w}) \\
\text { Patients with SZ or SZA }(\mathrm{n}=1,225) \\
\text { ASE } 5-10 \mathrm{mg} \text { BID } \\
\text { OLZ } 10-20 \mathrm{mg} / \mathrm{d}\end{array}$ & $\begin{array}{l}\text { 8\% (ASE 5-10 mg BID, n=76/908), 4\% (OLZ 10-20 } \\
\mathrm{mg} / \mathrm{d}, \mathrm{n}=11 / 311 \text { ) }\end{array}$ & NR & NR & usually mild & NR \\
\hline $\begin{array}{l}\text { Kane et al. (2011) } \\
\text { A7501012 } \\
\text { NCT00150176 }\end{array}$ & $\begin{array}{l}\text { RCT with PBO (26w) after 26w stabilization } \\
\text { Stable SZ (n=386) } \\
\text { ASE } 10 \mathrm{mg} \text { BID }\end{array}$ & $\begin{array}{l}\text { 2.1\% (ASE } 10 \mathrm{mg} \text { BID, } \mathrm{n}=4 / 194) \text { vs. } 1.6 \% \text { (PBO, } \\
\mathrm{n}=3 / 192)\end{array}$ & NR & NR & NR & $1.3 \%$ \\
\hline $\begin{array}{l}\text { Kane et al. (2010b) } \\
\text { HERA041023 } \\
\text { NCT00156104 }\end{array}$ & $\begin{array}{l}\text { Double-blind RCT with PBO and active control (6w) } \\
\text { Acute exacerbation of SZ }(\mathrm{n}=458) \\
\text { ASE 5-10 mg BID } \\
\text { HAL } 14 \mathrm{mg} \mathrm{BID}\end{array}$ & $\begin{array}{l}5 \% \text { (ASE } 5 \mathrm{mg} \text { BID, } \mathrm{n}=6 / 111), 12 \% \text { (ASE } 10 \mathrm{mg} \text { BID, } \\
\mathrm{n}=13 / 106), 15 \% \text { (HAL } 14 \mathrm{mg} \mathrm{BID}, \mathrm{n}=17 / 115) \text { vs. } 3 \% \\
(\mathrm{PBO}, \mathrm{n}=4 / 123)\end{array}$ & NR & NR & NR & NR \\
\hline $\begin{array}{l}\text { McIntyre et al. } \\
\text { (2010b) } \\
\text { ARES } 7501004 \\
\text { NCT00159744 }\end{array}$ & $\begin{array}{l}\text { RCT with PBO and active control }(3 \mathrm{w}) \\
\text { Acute manic or mixed episodes BP-I }(\mathrm{n}=488) \\
\text { ASE } 5-10 \mathrm{mg} \text { BID } \\
\text { OLZ } 5-20 \mathrm{mg} / \mathrm{d}\end{array}$ & $\begin{array}{l}\text { 5.4\% (ASE 5-10 mg BID, } \mathrm{n}=10 / 185), 4.9 \% \text { (OLZ 5-20 } \\
\text { mg/d, n=10/205), vs. 3.1\% (PBO, } \mathrm{n}=3 / 98) \\
\text { BARS: 8.5\% (ASE 5-10 mg BID, } \mathrm{n}=15 / 177), 3.7 \% \text { (OLZ } \\
\text { 5-20 mg/d, } \mathrm{n}=7 / 188 \text { ), vs. } 6.5 \% \text { (PBO, } \mathrm{n}=6 / 93 \text { ) }\end{array}$ & NR & NR & mild to moderate & NR \\
\hline $\begin{array}{l}\text { McIntyre et al. } \\
\text { (2009a) } \\
\text { ARES } 7501005 \\
\text { NCT00159796 } \\
\end{array}$ & $\begin{array}{l}\text { RCT with PBO and active control }(3 \mathrm{w}) \\
\text { Acute manic or mixed episodes BP-I }(\mathrm{n}=488) \\
\text { ASE } 5-10 \mathrm{mg} \text { BID } \\
\text { OLZ } 5-20 \mathrm{mg} / \mathrm{d}\end{array}$ & $\begin{array}{l}\text { 2.6\% (ASE 5-10 mg BID, } \mathrm{n}=5 / 194), 5.8 \% \text { (OLZ 5-20 } \\
\text { mg/d, n=11/189), vs. } 1.9 \% \text { (PBO, } \mathrm{n}=2 / 105) \\
\text { BARS: 7.4\% (ASE 5-10 mg BID, } \mathrm{n}=14 / 188), 7.9 \% \text { (OLZ } \\
\text { 5-20 mg/d, n=14/178), vs. 5.2\% (PBO, } \mathrm{n}=5 / 96)\end{array}$ & NR & NR & mild to moderate & NR \\
\hline \multicolumn{7}{|l|}{ LURASIDONE } \\
\hline $\begin{array}{l}\text { Suppes et al. (2016b) } \\
\text { NCT01423240 }\end{array}$ & $\begin{array}{l}\text { RCT with PBO (6w) } \\
\text { Patients with MDD with mixed features }(\mathrm{n}=209) \\
\text { LURA } 20-60 \mathrm{mg} / \mathrm{d}\end{array}$ & $\begin{array}{l}3.7 \%(\text { LURA } 20-60 \mathrm{mg} / \mathrm{d}, \mathrm{n}=4 / 109) \text { vs. } 2 \% \text { (PBO, } \\
\mathrm{n}=2 / 100)\end{array}$ & NR & NR & mild to moderate & NR \\
\hline $\begin{array}{l}\text { Suppes et al. (2016a) } \\
\text { NCT01284517 }\end{array}$ & $\begin{array}{l}\text { RCT with PBO (6w) } \\
\text { BP-I depression ( } \mathrm{n}=356) \\
\text { LURA } 20-120 \mathrm{mg} / \mathrm{d} \text { as adjunctive therapy with LI or VAL }\end{array}$ & $\begin{array}{l}14.1 \%(\text { LURA } 20-120 \mathrm{mg} / \mathrm{d}+\mathrm{LI} / \mathrm{VAL}, \mathrm{n}=25 / 177 \text { ) vs. } \\
5.3 \%(\mathrm{PBO}+\mathrm{LI} / \mathrm{VAL}, \mathrm{n}=9 / 171)\end{array}$ & $\mathrm{NR}$ & NR & NR & NR \\
\hline
\end{tabular}




\begin{tabular}{|c|c|c|c|c|c|c|}
\hline $\begin{array}{l}\text { Loebel et al. (2016) } \\
\text { NCT01821378 }\end{array}$ & $\begin{array}{l}\text { RCT with PBO }(6 \mathrm{w}) \\
\text { Acute exacerbation of SZ }(\mathrm{n}=412) \\
\text { LURA } 20-160 \mathrm{mg} / \mathrm{d}\end{array}$ & $\begin{array}{l}5 \% \text { (LURA } 20 \mathrm{mg} / \mathrm{d}, \mathrm{n}=5 / 101 \text { ), } 16 \% \text { (LURA } 80 \mathrm{mg} / \mathrm{d} \text {, } \\
\text { responders) } 3.6 \% \text { (LURA } 80 \mathrm{mg} / \mathrm{d} \text {, non-responders, } \\
\mathrm{n}=2 / 55 \text { ), } 7 \% \text { (LURA } 160 \mathrm{mg} / \mathrm{d}, \mathrm{n}=3 / 43 \text { ), vs. } 1.8 \% \text { (PBO, } \\
\mathrm{n}=2 / 112 \text { ) } \\
\text { Patients whose dose was increased from } 80 \text { to } 160 \mathrm{mg} / \mathrm{d} \\
\text { reported a greater incidence of akathisia } \\
\text { BARS changes small and not clinically meaningful in all } \\
\text { treatment groups }\end{array}$ & NR & NR & NR & NR \\
\hline Potkin et al. (2015) & $\begin{array}{l}\text { RCT with PBO and active control (Phase II) }(6 \mathrm{w}) \\
\text { Acute exacerbation of SZ }(\mathrm{n}=353) \\
\text { LURA } 20-80 \mathrm{mg} / \mathrm{d} \\
\text { HAL } 10 \mathrm{mg} / \mathrm{d}\end{array}$ & $\begin{array}{l}\text { 12.4\% (LURA overall), 5.6\% (LURA } 20 \mathrm{mg} / \mathrm{d}, \mathrm{n}=4 / 71 \text { ), } \\
13.4 \% \text { (LURA } 40 \mathrm{mg} / \mathrm{d}, \mathrm{n}=9 / 67), 18.3 \% \text { (LURA } 80 \mathrm{mg} / \mathrm{d} \text {, } \\
\mathrm{n}=13 / 71), 19.4 \% \text { (HAL } 10 \mathrm{mg} / \mathrm{d}, \mathrm{n}=14 / 72) \text { vs. } 9.7 \% \\
\text { (PBO, } \mathrm{n}=7 / 72) \\
\text { Dose-relationship for akathisia was apparent }\end{array}$ & NR & NR & mild to moderate & $\begin{array}{l}\text { Discontinuation } \\
\text { because of EPS or } \\
\text { akathisia: } 9.7 \% \\
\text { (HAL } 10 \mathrm{mg} / \mathrm{d} \text { ), } \\
0.5 \% \text { (LURA } \\
\text { across all dose } \\
\text { groups) vs. } 0 \% \\
\text { (PBO) }\end{array}$ \\
\hline $\begin{array}{l}\text { Loebel et al. (2014a) } \\
\text { NCT00868699 }\end{array}$ & $\begin{array}{l}\text { RCT with PBO (6w) } \\
\text { Patients with BP-I depression }(\mathrm{n}=505) \\
\text { LURA } 20-120 \mathrm{mg} / \mathrm{d}\end{array}$ & $\begin{array}{l}7.9 \%(\text { LURA } 20-60 \mathrm{mg} / \mathrm{d}, \mathrm{n}=13 / 164), 10.8 \% \text { (LURA 80- } \\
120 \mathrm{mg} / \mathrm{d}, \mathrm{n}=18 / 167) \text { vs. } 2.4 \%(\mathrm{PBO}, \mathrm{n}=4 / 168)\end{array}$ & NR & NR & mild to moderate & NR \\
\hline $\begin{array}{l}\text { Loebel et al. (2014b) } \\
\text { NCT00868452 }\end{array}$ & $\begin{array}{l}\text { RCT with PBO (6w) } \\
\text { Patients with BP-I depression ( } \mathrm{n}=348 \text { ) } \\
\text { LURA } 20-120 \mathrm{mg} / \mathrm{d} \text { as adjunctive therapy with LI or VAL }\end{array}$ & $\begin{array}{l}\text { 7.7\% (LURA + LI, } 897.2 \mathrm{mg} / \mathrm{d} / \mathrm{VAL}, 1058.3 \mathrm{mg} / \mathrm{d} \\
\mathrm{n}=14 / 183), 4.3 \%(\mathrm{PBO}+\mathrm{LI}, 947.3 \mathrm{mg} / \mathrm{d} / \mathrm{VAL} 1117.8 \\
\mathrm{mg} / \mathrm{d}, \mathrm{n}=7 / 163)\end{array}$ & NR & NR & mild to moderate & NR \\
\hline Ogasa et al. (2013) & $\begin{array}{l}\text { RCT with PBO }(6 \mathrm{w}) \\
\text { Acute exacerbation of } \mathrm{SZ}(\mathrm{n}=149) \\
\text { LURA } 40-120 \mathrm{mg} / \mathrm{d}\end{array}$ & $\begin{array}{l}11.1 \% \text { (LURA overall, } \mathrm{n}=11 / 99), 8 \% \text { (LURA } 40 \mathrm{mg} / \mathrm{d} \\
\mathrm{n}=4 / 50), 14.3 \% \text { (LURA } 120 \mathrm{mg} / \mathrm{d}, \mathrm{n}=7 / 49) \text { vs. } 0 \%(\text { PBO, } \\
\mathrm{n}=0 / 50)\end{array}$ & NR & NR & mild to moderate & $\begin{array}{l}\text { Discontinuation } \\
\text { because } \\
\text { of EPS or } \\
\text { akathisia: } 2 \% \\
\text { (LURA } 40 \mathrm{mg} / \mathrm{d} \text { ), } \\
4.1 \%(\mathrm{LURA} \\
120 \mathrm{mg} / \mathrm{d} \text { ) }\end{array}$ \\
\hline $\begin{array}{l}\text { Loebel et al. (2013a) } \\
\text { NCT00790192 } \\
\text { D1050233 }\end{array}$ & $\begin{array}{l}\text { RCT with PBO and active control }(6 \mathrm{w}) \\
\text { Acute exacerbation of } \mathrm{SZ}(\mathrm{n}=486) \\
\text { LURA } 80-160 \mathrm{mg} / \mathrm{d} \\
\text { QUE XR } 600 \mathrm{mg} / \mathrm{d}\end{array}$ & $\begin{array}{l}8.0 \%(\text { LURA } 80 \mathrm{mg} / \mathrm{d}, \mathrm{n}=10 / 125), 7.4 \% \text { (LURA } 160 \\
\mathrm{mg} / \mathrm{d}, \mathrm{n}=9 / 121), 1.7 \%(\mathrm{QUE} \text { XR } 600 \mathrm{mg} / \mathrm{d}, \mathrm{n}=2 / 119) \text { vs. } \\
0.8 \%(\mathrm{PBO}, \mathrm{n}=1 / 121)\end{array}$ & NR & NR & mild to moderate & $\begin{array}{l}1.6 \% \text { (LURA } 80 \\
\mathrm{mg} / \mathrm{d}), 0.8 \% \\
(\text { LURA } \\
160 \mathrm{mg} / \mathrm{d}), 0 \% \\
(\mathrm{QUE} \text { XR } 600 \\
\mathrm{mg} / \mathrm{d} \text { and } \mathrm{PBO})\end{array}$ \\
\hline $\begin{array}{l}\text { Nasrallah et al. } \\
\text { (2013) } \\
\text { NCT00549718 } \\
\text { D1050229 }\end{array}$ & $\begin{array}{l}\text { RCT with PBO }(6 \mathrm{w})(\text { Phase III) } \\
\text { Acute exacerbation of SZ }(\mathrm{n}=495) \\
\text { LURA } 40-120 \mathrm{mg} / \mathrm{d}\end{array}$ & $\begin{array}{l}\text { 17.6\% (LURA overall), } 11.3 \% \text { (LURA } 40 \mathrm{mg} / \mathrm{d} \text {, } \\
\mathrm{n}=14 / 124), 17.4 \% \text { (LURA } 80 \mathrm{mg} / \mathrm{d}, \mathrm{n}=21 / 121 \text { ), and } \\
24.2 \% \text { (LURA } 120 \mathrm{mg} / \mathrm{d}, \mathrm{n}=30 / 124) \text { vs. } 3.1 \% \text { (PBO, } \\
\mathrm{n}=4 / 127 \text { ) }\end{array}$ & NR & NR & $\begin{array}{l}\text { mild to moderate } \\
\text { Akathisia was } \\
\text { rated as mild in } \\
7.6 \% \text { of patients } \\
\text { receiving LURA, } \\
\text { moderate in } \\
8.9 \% \text { of patients, } \\
\text { and severe in } \\
1.1 \% \text { of patients. } \\
\text { Scores in the }\end{array}$ & $\begin{array}{l}1.6 \%(\text { LURA } 40 \\
\mathrm{mg} / \mathrm{d}), 0.8 \% \\
\text { (LURA } 80 \mathrm{mg} / \mathrm{d}) \text {, } \\
2.4 \%(\text { LURA } 120 \\
\mathrm{mg} / \mathrm{d})\end{array}$ \\
\hline
\end{tabular}




\begin{tabular}{|c|c|c|c|c|c|c|}
\hline & & & & & $\begin{array}{l}\text { moderate to } \\
\text { severe range on } \\
\text { the BARS Global } \\
\text { Clinical } \\
\text { Assessment } \\
\text { (scores } \geq 3 \text { ): } 2.5 \% \\
\text { (LURA } 40 \mathrm{mg} / \mathrm{d} \text { ), } \\
2.5 \% \text { (LURA } 80 \\
\text { mg/d), and } 4.0 \% \\
\text { (LURA } 120 \mathrm{mg} / \mathrm{d} \text { ) } \\
\text { vs. } 0 \% \text { (PBO). }\end{array}$ & \\
\hline $\begin{array}{l}\text { Citrome et al. } \\
(2012 \mathrm{a}) \\
\text { NCT00641745 }\end{array}$ & $\begin{array}{l}\text { RCT with active control }(52 \mathrm{w}) \\
\text { Stable outpatients with SZ }(\mathrm{n}=629) \\
\text { LURA } 40-120 \mathrm{mg} / \mathrm{d} \\
\text { RIS 2-6 } \mathrm{mg} / \mathrm{d}\end{array}$ & $\begin{array}{l}\text { 14.3\% (LURA 40-120 mg/d, } \mathrm{n}=60 / 419), 7.9 \% \text { (RIS 2-6 } \\
\mathrm{mg} / \mathrm{d}, \mathrm{n}=16 / 202 \text { ) }\end{array}$ & NR & NR & mild to moderate & $\begin{array}{l}1 \%(\text { LURA } 40- \\
120 \mathrm{mg} / \mathrm{d}), 1.5 \% \\
\text { (RIS } 2-6 \mathrm{mg} / \mathrm{d})\end{array}$ \\
\hline $\begin{array}{l}\text { Meltzer et al. (2011) } \\
\text { NCT00615433 } \\
\text { D1050231 }\end{array}$ & $\begin{array}{l}\text { RCT with PBO and active control }(6 \mathrm{w}) \\
\text { Acute exacerbation of SZ }(\mathrm{n}=478) \\
\text { LURA } 40-120 \mathrm{mg} / \mathrm{d} \\
\text { OLZ } 15 \mathrm{mg} / \mathrm{d}\end{array}$ & $\begin{array}{l}11.8 \% \text { (LURA } 40 \mathrm{mg} / \mathrm{d}, \mathrm{n}=14 / 119), 22.9 \% \text { (LURA } 120 \\
\mathrm{mg} / \mathrm{d}, \mathrm{n}=27 / 118), 7.4 \% \text { (OLZ } 15 \mathrm{mg} / \mathrm{d}, \mathrm{n}=9 / 122) \text { vs. } 0.9 \% \\
(\mathrm{PBO}, \mathrm{n}=1 / 116)\end{array}$ & NR & NR & mild to moderate & 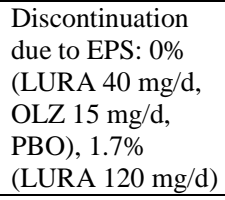 \\
\hline Potkin et al. (2011) & $\begin{array}{l}\text { RCT with active control }(3 \mathrm{w}) \\
\text { Patients with SZ or SZA }(\mathrm{n}=301) \\
\text { ZIPRA } 160 \mathrm{mg} / \mathrm{d} \\
\text { LURA } 120 \mathrm{mg} / \mathrm{d}\end{array}$ & $\begin{array}{l}3.3 \% \text { (LURA } 120 \mathrm{mg} / \mathrm{d}, \mathrm{n}=5 / 150), 6.6 \% \text { (ZIPRA } 160 \\
\mathrm{mg} / \mathrm{d}, \mathrm{n}=10 / 151 \text { ) }\end{array}$ & $\mathrm{NR}$ & NR & mild to moderate & $\mathrm{NR}$ \\
\hline $\begin{array}{l}\text { Nakamura et al. } \\
\text { (2009) } \\
\text { NCT00088634 } \\
\text { D1050196 }\end{array}$ & $\begin{array}{l}\text { RCT with PBO (Phase II) }(6 \mathrm{w}) \\
\text { Patients with acute exacerbation of SZ (n=180) } \\
\text { LURA } 80 \mathrm{mg} / \mathrm{d}\end{array}$ & $8.9 \%($ LURA $80 \mathrm{mg} / \mathrm{d}, \mathrm{n}=8 / 90)$ vs. $3.3 \%(\mathrm{PBO}, \mathrm{n}=3 / 90)$ & NR & NR & $\begin{array}{l}\text { mild to moderate } \\
\text { (one event of } \\
\text { akathisia in } \\
\text { LURA group } \\
\text { rated as severe) }\end{array}$ & $\begin{array}{l}2.2 \% \text { (LURA } 80 \\
\mathrm{mg} / \mathrm{d}) \text { vs. } 0 \% \\
\text { (PBO) }\end{array}$ \\
\hline NCT01358357 & $\begin{array}{l}\text { RCT with PBO (Phase III) } \\
\text { Patients with BP-I with or without rapid cycling and/or } \\
\text { psychotic features }(\mathrm{n}=496) \\
\text { LURA } 20-80 \mathrm{mg} / \mathrm{d} \text { as adjunctive therapy with LI or VAL }\end{array}$ & $\begin{array}{l}\text { 3.66\% (LURA } 20-80 \mathrm{mg} / \mathrm{d}, \mathrm{n}=9 / 246) \text { vs. } 3.20 \%(\mathrm{PBO} \text {, } \\
\mathrm{n}=8 / 250)\end{array}$ & NR & NR & NR & NR \\
\hline NCT00044044 & $\begin{array}{l}\text { RCT with PBO and active control (Phase II) }(6 \mathrm{w}) \\
\text { Patients with acute exacerbation of SZ (n=353) } \\
\text { LURA } 20-80 \mathrm{mg} / \mathrm{d} \\
\text { HAL } 10 \mathrm{mg} / \mathrm{d}\end{array}$ & $\begin{array}{l}5.63 \% \text { (LURA } 20 \mathrm{mg} / \mathrm{d}, \mathrm{n}=4 / 71), 13.43 \% \text { (LURA } 40 \\
\mathrm{mg} / \mathrm{d}, \mathrm{n}=9 / 67), 18.31 \% \text { (LURA } 80 \mathrm{mg} / \mathrm{d}, \mathrm{n}=13 / 71), \\
19.44 \%(\text { HAL } 10 \mathrm{mg} / \mathrm{d}, \mathrm{n}=14 / 72) \text { vs. } 9.72 \% \text { (PBO, } \\
\mathrm{n}=7 / 72)\end{array}$ & NR & NR & NR & NR \\
\hline \multicolumn{7}{|l|}{ BREXPIPRAZOLE } \\
\hline $\begin{array}{l}\text { Ishigooka et al. } \\
\text { (2018) } \\
\text { NCT01451164 }\end{array}$ & $\begin{array}{l}\text { RCT with PBO (Phase II/III) (6w) } \\
\text { Acute exacerbation of SZ (n=459) } \\
\text { BREX } 1-4 \mathrm{mg} / \mathrm{d}\end{array}$ & $\begin{array}{l}\text { 1.7\% (BREX } 1 \mathrm{mg} / \mathrm{d}, \mathrm{n}=2 / 115), 3.5 \%(\mathrm{BREX} 2 \mathrm{mg} / \mathrm{d} \text {, } \\
\mathrm{n}=4 / 114), 5.3 \%(\text { BREX } 4 \mathrm{mg} / \mathrm{d}, \mathrm{n}=6 / 113) \text { vs. } 6.9 \%(\mathrm{PBO}, \\
\mathrm{n}=8 / 116)\end{array}$ & $\begin{array}{l}\text { Most } \\
\text { frequently } \\
\text { during first } \\
3 \mathrm{w} \\
\end{array}$ & NR & mild to moderate & $0 \%$ \\
\hline $\begin{array}{l}\text { Hobart (2018a) } \\
\text { NCT02196506 } \\
\end{array}$ & $\begin{array}{l}\text { RCT with PBO (6w) } \\
\text { Patients with MDD (n=394) }\end{array}$ & $8.3 \%(\mathrm{AD}+\mathrm{BREX} 2 \mathrm{mg} / \mathrm{d}, \mathrm{n}=16 / 192)$ vs.5\% (AD+PBO) & NR & NR & mild to moderate & NR \\
\hline
\end{tabular}




\begin{tabular}{|c|c|c|c|c|c|c|}
\hline (SIRIUS trial) & Adjunctive BREX $2 \mathrm{mg} / \mathrm{d}$ & & & & & \\
\hline $\begin{array}{l}\text { Hobart }(2018 \mathrm{~b}) \\
\text { NCT01727726 } \\
\text { (DELPHINUS trial) }\end{array}$ & $\begin{array}{l}\text { RCT with PBO and active control (6w) } \\
\text { Patients with MDD }(\mathrm{n}=503) \\
\text { Adjunctive BREX } 2-3 \mathrm{mg} / \mathrm{d} \\
\text { QUE XR } 150-300 \mathrm{mg} / \mathrm{d} \\
\end{array}$ & $\begin{array}{l}\text { 6.1\% (AD+BREX 2-3 mg/d, } \mathrm{n}=12 / 197), 3 \%(\mathrm{AD}+\mathrm{QUE} \\
\mathrm{XR} 150-300 \mathrm{mg} / \mathrm{d}, \mathrm{n}=3 / 100) \text { vs. } 1.9 \%(\mathrm{AD}+\mathrm{PBO}, \\
\mathrm{n}=4 / 206)\end{array}$ & NR & NR & mild to moderate & NR \\
\hline $\begin{array}{l}\text { Fleischhacker et al. } \\
\text { (2017) } \\
\text { NCT01668797 } \\
\text { (EQUATOR trial) }\end{array}$ & $\begin{array}{l}\text { RCT with PBO (52w) (Phase III) } \\
\text { Acute exacerbation of SZ ( } \mathrm{n}=201) \\
\text { BREX 1-4 mg/d }\end{array}$ & $1 \%($ BREX $1-4 \mathrm{mg} / \mathrm{d}, \mathrm{n}=1 / 97)$ vs. $1 \%(\mathrm{PBO}, \mathrm{n}=1 / 104)$ & $\mathrm{NR}$ & NR & mild to moderate & $0 \%$ \\
\hline $\begin{array}{l}\text { Correll }(2016 \mathrm{~b}) / \\
\text { NCT00905307 } \\
\text { STEP } 203\end{array}$ & $\begin{array}{l}\text { RCT with PBO and active control }(6 \mathrm{w}) \\
\text { Acute exacerbation of } \mathrm{SZ}(\mathrm{n}=459) \\
\text { BREX } 0.25-6 \mathrm{mg} / \mathrm{d} \\
\text { ARIPI } 10-20 \mathrm{mg} / \mathrm{d}\end{array}$ & $\begin{array}{l}2.4 \% \text { (BREX } 0.25 \mathrm{mg} / \mathrm{d}, \mathrm{n}=1 / 42), 6.7 \% \text { (BREX } 1 \pm 0.5 \\
\mathrm{mg} / \mathrm{d}, \mathrm{n}=6 / 89), 5.6 \% \text { (BREX } 2.5 \pm 0.5 \mathrm{mg} / \mathrm{d}, \mathrm{n}=5 / 90) \\
15.1 \% \text { (BREX } 5 \pm 1 \mathrm{mg} / \mathrm{d}, \mathrm{n}=14 / 93 \text { ), } 4 \% \text { (ARIPI } 10-20 \\
\mathrm{mg} / \mathrm{d}, \mathrm{n}=2 / 50) \text { vs. } 4.2 \%(\text { PBO, } \mathrm{n}=4 / 95 \text { ) }\end{array}$ & NR & NR & NR & NR \\
\hline $\begin{array}{l}\text { Citrome et al. (2016) } \\
\text { NCT02054702 }\end{array}$ & $\begin{array}{l}\text { RCT with active control }(6 \mathrm{w})(\text { Phase IIIb) } \\
\text { Acute exacerbation of SZ }(\mathrm{n}=97) \\
\text { BREX } 1-4 \mathrm{mg} / \mathrm{d} \\
\text { ARIPI } 10-20 \mathrm{mg} / \mathrm{d}\end{array}$ & $\begin{array}{l}9.4 \% \text { (BREX } 1-4 \mathrm{mg} / \mathrm{d}, \mathrm{n}=6 / 64), 21.2 \% \text { (ARIPI 10-20 } \\
\mathrm{mg} / \mathrm{d}, \mathrm{n}=7 / 33 \text { ) }\end{array}$ & NR & NR & mild to moderate & NR \\
\hline $\begin{array}{l}\text { Correll et al. (2015a) } \\
\text { NCT01396421 } \\
\text { (VECTOR trial) }\end{array}$ & $\begin{array}{l}\text { RCT with PBO (Phase III) }(6 \mathrm{w}) \\
\text { Acute exacerbation of SZ }(\mathrm{n}=636) \\
\text { BREX } 0.25-4 \mathrm{mg} / \mathrm{d}\end{array}$ & $\begin{array}{l}0 \%(\text { BREX } 0.25 \mathrm{mg} / \mathrm{d}, \mathrm{n}=0 / 90), 4.4 \%(\text { BREX } 2 \mathrm{mg} / \mathrm{d} \text {, } \\
\mathrm{n}=8 / 182), 7.2 \%(\text { BREX } 4 \mathrm{mg} / \mathrm{d}, \mathrm{n}=13 / 180) \text { vs. } 2.2 \% \\
(\mathrm{PBO}, \mathrm{n}=4 / 184)\end{array}$ & $\begin{array}{l}\text { Most often } \\
\text { during first } 3 \\
\text { weeks of } \\
\text { treatment }\end{array}$ & NR & mild to moderate & $0 \%$ \\
\hline $\begin{array}{l}\text { Kane et al. }(2015 b) \\
\text { NCT01393613 } \\
\text { (BEACON trial) }\end{array}$ & $\begin{array}{l}\text { RCT with PBO (Phase III) (6w) } \\
\text { Acute exacerbation of SZ ( } \mathrm{n}=674) \\
\text { BREX } 1-4 \mathrm{mg} / \mathrm{d}\end{array}$ & $\begin{array}{l}\text { 4.2\% (BREX } 1 \mathrm{mg} / \mathrm{d}, \mathrm{n}=5 / 120), 4.8 \% \text { (BREX } 2 \mathrm{mg} / \mathrm{d} \text {, } \\
\mathrm{n}=9 / 186), 6.5 \% \text { (BREX } 4 \mathrm{mg} / \mathrm{d}, \mathrm{n}=12 / 184) \text { vs. } 7.1 \% \\
\text { (PBO, n=13/184) } \\
\text { *patients presenting with severe akathisia at baseline were } \\
\text { excluded from the study, possibly explaining the low } \\
\text { levels of akathisia }\end{array}$ & $\begin{array}{l}\text { Mostly during } \\
\text { first } 3 \text { weeks } \\
\text { of treatment }\end{array}$ & NR & mild to moderate & $0 \%$ \\
\hline $\begin{array}{l}\text { Thase et al. (2015a) } \\
\text { (POLARIS trial) } \\
\text { NCT01360632 }\end{array}$ & $\begin{array}{l}\text { RCT with PBO (Phase III) (6w) } \\
\text { Patients with MDD (n=677) } \\
\text { BREX 1-3 mg/d }\end{array}$ & $\begin{array}{l}4.4 \%(\text { BREX } 1 \mathrm{mg} / \mathrm{d}, \mathrm{n}=10 / 226), 13.5 \%(\mathrm{BREX} 3 \mathrm{mg} / \mathrm{d} \text {, } \\
\mathrm{n}=31 / 229) \text { vs. } 2.3 \%(\mathrm{PBO}, \mathrm{n}=5 / 220)\end{array}$ & NR & NR & mild to moderate & $\begin{array}{l}2.2 \%(\text { BREX } 3 \\
\mathrm{mg} / \mathrm{d})\end{array}$ \\
\hline $\begin{array}{l}\text { Thase et al. (2015b) } \\
\text { (PYXIS trial) } \\
\text { NCT01360645 }\end{array}$ & $\begin{array}{l}\text { RCT with PBO (Phase III) (6w) } \\
\text { Patients with MDD (n=379) } \\
\text { BREX } 2 \text { mg/d }\end{array}$ & $7.4 \%$ (BREX $2 \mathrm{mg} / \mathrm{d}, \mathrm{n}=14 / 188)$ vs. $1 \%(\mathrm{PBO}, \mathrm{n}=2 / 191)$ & NR & NR & mild to moderate & $\begin{array}{l}0.5 \%(\text { BREX } 2 \\
\mathrm{mg} / \mathrm{d})\end{array}$ \\
\hline $\begin{array}{l}\text { NCT01810380 } \\
\text { (LIGHTHOUSE } \\
\text { trial) } \\
\text { (cited in Marder et } \\
\text { al., 2017) }\end{array}$ & $\begin{array}{l}\text { RCT with PBO and active control }(6 \mathrm{w}) \\
\text { Acute exacerbation of SZ }(\mathrm{n}=311) \\
\text { BREX 2-4 mg/d } \\
\text { QUE XR 400-800 mg }\end{array}$ & $6 \%(\mathrm{BREX} 2-4 \mathrm{mg}, \mathrm{n}=9 / 150)$ vs. $2.5 \%(\mathrm{PBO}, \mathrm{n}=4 / 161)$ & NR & NR & NR & $0 \%$ \\
\hline NCT00797966 & $\begin{array}{l}\text { RCT with PBO (Phase II) }(14 \mathrm{w}) \\
\text { Patients with MDD }(\mathrm{n}=429) \\
\text { AD+BREX } 1-4 \mathrm{mg} / \mathrm{d}\end{array}$ & $\begin{array}{l}6.5 \%(\text { BREX } 0.15 \mathrm{mg} / \mathrm{d}, \mathrm{n}=4 / 62), 5 \%(\text { BREX } 0.5 \pm 0.25 \\
\mathrm{mg} / \mathrm{d}, \mathrm{n}=6 / 120), 8.3 \%(\text { BREX } 1.5 \pm 0.5 \mathrm{mg} / \mathrm{d}, \mathrm{n}=10 / 121) \\
\text { vs. } 3.2 \%(\text { PBO, } \mathrm{n}=4 / 126)\end{array}$ & NR & NR & NR & NR \\
\hline
\end{tabular}




\begin{tabular}{|c|c|c|c|c|c|c|}
\hline $\begin{array}{l}\text { NCT01052077 } \\
\text { STEP-D222 } \\
\text { Cited in Yoon } \\
\text { (2017)+Nelson } \\
\text { (2016) }\end{array}$ & $\begin{array}{l}\text { RCT with PBO (6w) } \\
\text { Patients with MDD }(\mathrm{n}=372) \\
\text { AD+BREX } 1-3 \mathrm{mg} / \mathrm{d}\end{array}$ & $\begin{array}{l}11.9 \%(\mathrm{AD}+\mathrm{BREX} 1-3 \mathrm{mg} / \mathrm{d}, \mathrm{n}=22 / 185) \text { vs. } 4.81 \% \\
(\mathrm{AD}+\mathrm{PBO}, \mathrm{n}=9 / 187)\end{array}$ & NR & NR & NR & NR \\
\hline \multicolumn{7}{|l|}{ CARIPRAZINE } \\
\hline Németh et al. (2017) & $\begin{array}{l}\text { RCT with PBO and active control (26w) (Phase IIIb) } \\
\text { SZ with predominant negative symptoms }(\mathrm{n}=461) \\
\text { CARI } 3-6 \mathrm{mg} / \mathrm{d} \\
\text { RIS } 3-6 \mathrm{mg} / \mathrm{d}\end{array}$ & $\begin{array}{l}\text { 12\% (CARI overall, } \mathrm{n}=19 / 230), 9 \% \text { (RIS overall, } \\
\mathrm{n}=12 / 230)\end{array}$ & NR & NR & mild to moderate & $\mathrm{NR}$ \\
\hline $\begin{array}{l}\text { Durgam et al. } \\
(2016 a) \\
\text { NCT01396447 }\end{array}$ & $\begin{array}{l}\text { RCT with PBO }(8 \mathrm{w}) \\
\text { BP-I depression }(\mathrm{n}=571) \\
\text { CARI } 0.75-3 \mathrm{mg} / \mathrm{d}\end{array}$ & $\begin{array}{l}2.8 \%(\text { CARI } 0.75 \mathrm{mg} / \mathrm{d}, \mathrm{n}=4 / 141), 4.8 \% \text { (CARI } 1.5 \mathrm{mg} / \mathrm{d} \text {, } \\
\mathrm{n}=7 / 146), 14.4 \% \text { (CARI } 3 \mathrm{mg} / \mathrm{d}, \mathrm{n}=21 / 146) \text { vs. } 1.4 \% \\
(\text { PBO, } \mathrm{n}=2 / 145)\end{array}$ & NR & NR & $\begin{array}{l}\text { mild to moderate } \\
(94 \%)\end{array}$ & $\begin{array}{l}3 \%(\text { CARI } 3 \\
\mathrm{mg} / \mathrm{d})\end{array}$ \\
\hline $\begin{array}{l}\text { Durgam et al. } \\
(2016 \mathrm{~b}) \\
\text { NCT01469377 }\end{array}$ & $\begin{array}{l}\text { RCT with PBO }(8 \mathrm{w}) \\
\text { Patients with MDD (n=819) } \\
\text { AD+CARI } 1-4.5 \mathrm{mg} / \mathrm{d}\end{array}$ & $\begin{array}{l}6.6 \%(A D+C A R I 1-2 \mathrm{mg} / \mathrm{d}, \mathrm{n}=18 / 273), 22.3 \% \\
(\mathrm{AD}+\mathrm{CARI} 2-4.5 \mathrm{mg} / \mathrm{d}, \mathrm{n}=61 / 273) \text { vs. } 2.3 \%(\mathrm{AD}+\mathrm{PBO} \text {, } \\
\mathrm{n}=6 / 266)\end{array}$ & NR & NR & mild to moderate & $\begin{array}{l}0.4 \%(\mathrm{AD}+\mathrm{CARI} \\
1-2 \mathrm{mg} / \mathrm{d}), 4.8 \% \\
(\mathrm{AD}+\mathrm{CARI} 2-4.5 \\
\mathrm{mg} / \mathrm{d}) \\
\end{array}$ \\
\hline $\begin{array}{l}\text { Durgam et al. } \\
(2016 \mathrm{c}) \\
\text { NCT00404573 } \\
\text { RGH-MD-03 }\end{array}$ & $\begin{array}{l}\text { RCT with PBO (6w) } \\
\text { Acute exacerbation of SZ (n=392) } \\
\text { CARI } 1.5-12 \mathrm{mg} / \mathrm{d}\end{array}$ & $\begin{array}{l}\text { 10.2\% (CARI } 1.5-4.5 \mathrm{mg} / \mathrm{d}, \mathrm{n}=13 / 127), 9 \% \text { (CARI 6-12 } \\
\mathrm{mg} / \mathrm{d}, \mathrm{n}=12 / 133) \text { vs. } 0.8 \%(\mathrm{PBO}, \mathrm{n}=1 / 129)\end{array}$ & NR & NR & mild to moderate & $\begin{array}{l}0.8 \% \text { (CARI } 1.5- \\
4.5 \mathrm{mg} / \mathrm{d}) \text { and } \\
2.3 \% \text { (CARI } 6-12 \\
\mathrm{mg} / \mathrm{d}) \text { vs. } 0 \% \\
\text { (PBO) }\end{array}$ \\
\hline $\begin{array}{l}\text { Durgam et al. } \\
(2016 \mathrm{~d}) \\
\text { NCT01412060 }\end{array}$ & $\begin{array}{l}\text { RCT with PBO (46w) } \\
\text { Patients with SZ }(\mathrm{n}=200) \\
\text { CARI } 3-9 \mathrm{mg} / \mathrm{d}\end{array}$ & $5 \%$ (CARI 3-9 mg/d, $\mathrm{n}=5 / 101)$ vs. $3 \%(\mathrm{PBO}, \mathrm{n}=3 / 99)$ & NR & NR & $\begin{array}{l}\text { mild to moderate } \\
(>98 \%)\end{array}$ & $\begin{array}{l}\text { 0\% (CARI 3-9 } \\
\mathrm{mg} / \mathrm{d})\end{array}$ \\
\hline $\begin{array}{l}\text { Durgam et al. } \\
(2015 \mathrm{a}) \\
\text { NCT00488618 }\end{array}$ & $\begin{array}{l}\text { RCT with PBO (phase II) }(3 \mathrm{w}) \\
\text { Acute manic or mixed episodes BP-I }(\mathrm{n}=236) \\
\text { CARI } 3-12 \mathrm{mg} / \mathrm{d}(3 \mathrm{w})\end{array}$ & $\begin{array}{l}\text { 18.6\% (CARI } 3-12 \mathrm{mg} / \mathrm{d}, \mathrm{n}=22 / 118) \text { vs. } 5.9 \%(\mathrm{PBO}, \\
\mathrm{n}=7 / 118)\end{array}$ & NR & NR & mild to moderate & $\begin{array}{l}1.7 \% \text { (CARI } 3-12 \\
\text { mg/d) vs. } 0 \% \\
\text { (PBO) }\end{array}$ \\
\hline $\begin{array}{l}\text { Durgam et al. } \\
(2015 b) \\
\text { NCT01104766 } \\
\text { RGH-MD-04 }\end{array}$ & $\begin{array}{l}\text { RCT with PBO and active control }(6 \mathrm{w}) \\
\text { Acute exacerbation of } \mathrm{SZ}(\mathrm{n}=617) \\
\text { CARI } 3-6 \mathrm{mg} / \mathrm{d} \\
\text { ARIPI } 10 \mathrm{mg} / \mathrm{d}\end{array}$ & $\begin{array}{l}\text { 7.1\% (CARI } 3 \mathrm{mg} / \mathrm{d}, \mathrm{n}=11 / 155), 14.6 \% \text { (CARI } 6 \mathrm{mg} / \mathrm{d} \text {, } \\
\mathrm{n}=23 / 157), 7.2 \%(\text { ARIPI } 10 \mathrm{mg} / \mathrm{d}, \mathrm{n}=11 / 152) \text { vs. } 4.6 \% \\
(\mathrm{PBO}, \mathrm{n}=7 / 153)\end{array}$ & NR & NR & mild to moderate & $\begin{array}{l}1.9 \%(\text { CARI } 3 \\
\mathrm{mg} / \mathrm{d}), 0.6 \% \\
\text { (CARI } 6 \mathrm{mg} / \mathrm{d}) \\
0 \%(\text { ARIPI } 10 \\
\mathrm{mg} / \mathrm{d})\end{array}$ \\
\hline $\begin{array}{l}\text { Sachs et al. (2015) } \\
\text { NCT01058096 }\end{array}$ & $\begin{array}{l}\text { RCT with PBO (Phase III) }(3 \mathrm{w}) \\
\text { Acute manic or mixed episodes BP-I }(\mathrm{n}=312) \\
\text { CARI } 3-12 \mathrm{mg} / \mathrm{d}\end{array}$ & $\begin{array}{l}22.2 \%(\text { CARI } 3-12 \mathrm{mg} / \mathrm{d}, \mathrm{n}=35 / 158) \text { vs. } 4.5 \% \text { (PBO, } \\
\mathrm{n}=7 / 154)\end{array}$ & NR & NR & mild to moderate & $\begin{array}{l}3.2 \% \text { (CARI } 3-12 \\
\mathrm{mg} / \mathrm{d}) \mathrm{vs} .0 \% \\
\text { (PBO) }\end{array}$ \\
\hline $\begin{array}{l}\text { Kane et al. (2015b) } \\
\text { NCT01104779 } \\
\text { RGH-MD-05 }\end{array}$ & $\begin{array}{l}\text { RCT with PBO (Phase III) (6w) } \\
\text { Acute exacerbation of SZ (n=446) } \\
\text { CARI 3-9 mg/d }\end{array}$ & $\begin{array}{l}15.9 \%(\text { CARI } 3-6 \mathrm{mg} / \mathrm{d}, \mathrm{n}=24 / 151), 16.9 \% \text { (CARI 6-9 } \\
\mathrm{mg} / \mathrm{d}, \mathrm{n}=25 / 148) \text { vs. } 3.4 \%(\mathrm{PBO}, \mathrm{n}=5 / 147)\end{array}$ & NR & NR & $\begin{array}{l}\text { mild to moderate } \\
(100 \%)\end{array}$ & $\begin{array}{l}\text { None of the } \\
\text { patients from the } \\
\text { CARI } 3-6 \mathrm{mg} / \mathrm{d}\end{array}$ \\
\hline
\end{tabular}




\begin{tabular}{|c|c|c|c|c|c|c|}
\hline & & & & & & $\begin{array}{l}\text { group and only } 1 \\
\text { patient from the } \\
\text { CARI 6-9 } \mathrm{mg} / \mathrm{d} \\
\text { group } \\
\text { discontinued due } \\
\text { to akathisia }\end{array}$ \\
\hline $\begin{array}{l}\text { Calabrese et al. } \\
(2015) \\
\text { NCT01058668 }\end{array}$ & $\begin{array}{l}\text { RCT with PBO (Phase III) }(3 \mathrm{w}) \\
\text { Acute manic or mixed episodes BP-I }(\mathrm{n}=497) \\
\text { CARI } 3-12 \mathrm{mg} / \mathrm{d}\end{array}$ & $\begin{array}{l}\text { 17.4\% (CARI 3-6 mg/d, } \mathrm{n}=29 / 167), 21.9 \% \text { (CARI 6-12 } \\
\mathrm{mg} / \mathrm{d}, \mathrm{n}=37 / 169) \text { vs. } 3.7 \%(\mathrm{PBO}, \mathrm{n}=6 / 161)\end{array}$ & NR & NR & mild to moderate & $\begin{array}{l}\text { 2\% (CARI 3-6 } \\
\mathrm{mg} / \mathrm{d}), 3 \% \text { (CARI } \\
6-12 \mathrm{mg} / \mathrm{d}) \text { vs. } 0 \% \\
(\mathrm{PBO})\end{array}$ \\
\hline $\begin{array}{l}\text { Durgam et al. (2014) } \\
\text { NCT00694707 } \\
\text { RGH-MD-16 }\end{array}$ & $\begin{array}{l}\text { RCT with PBO and active control }(6 \mathrm{w}) \\
\text { Acute exacerbation of } \mathrm{SZ}(\mathrm{n}=617) \\
\text { CARI } 1.5-4.5 \mathrm{mg} / \mathrm{d} \\
\text { RIS } 4 \mathrm{mg} / \mathrm{d}\end{array}$ & $\begin{array}{l}9 \% \text { (CARI } 1.5 \mathrm{mg} / \mathrm{d}, \mathrm{n}=13 / 145), 9.6 \% \text { (CARI } 3 \mathrm{mg} / \mathrm{d} \text {, } \\
\mathrm{n}=14 / 146), 7.5 \% \text { (CARI } 4.5 \mathrm{mg} / \mathrm{d}, \mathrm{n}=11 / 147), 8.6 \% \text { (RIS } \\
4 \mathrm{mg} / \mathrm{d}, \mathrm{n}=12 / 140) \text { vs. } 4.6 \% \text { (PBO, } \mathrm{n}=7 / 151 \text { ) }\end{array}$ & NR & NR & $\begin{array}{l}\text { mild } \\
\text { (approximately } \\
70 \% \text { in each } \\
\text { group) }\end{array}$ & $\begin{array}{l}\text { Less than } 2 \\
\text { patients } \\
\text { discontinuated } \\
\text { due to akathisia }\end{array}$ \\
\hline NCT00852202 & $\begin{array}{l}\text { RCT with PBO (Phase II) }(8 \mathrm{w}) \\
\text { Bipolar depression }(\mathrm{n}=234) \\
\text { CARI } 0.25-3 \mathrm{mg} / \mathrm{d}\end{array}$ & $\begin{array}{l}2.7 \%(\text { CARI } 0.25-0.75 \mathrm{mg} / \mathrm{d}, \mathrm{n}=2 / 75), 17.3 \% \text { (CARI } 1.5- \\
3 \mathrm{mg} / \mathrm{d}, \mathrm{n}=13 / 75) \text { vs. } 6.5 \%(\mathrm{PBO}, \mathrm{n}=5 / 77)\end{array}$ & $\mathrm{NR}$ & NR & $\mathrm{NR}$ & NR \\
\hline
\end{tabular}

AD: Antidepressant; ARIPI: Aripiprazole; ASE: Asenapine; BARS: Barnes Akathisia Rating Scale; BID: Twice Daily; BP-I: Bipolar I Disorder; BREX: Brexpiprazole; CARI: Cariprazine; D: Days; EPS:

Extrapyramidal Symptoms; HAL: Haloperidol; ILO: Iloperidone; LI: Lithium; LURA: Lurasidone; MDD: Major Depressive Disorder; NR: Not Reported; OLZ: Olanzapine; PBO: Placebo; QUE:

Quetiapine; QUE XR: Quetiapine Extended-Release; RCT: Randomized Controlled Trial: RIS: Risperidone; SZ: Schizophrenia; SZA: Schizoaffective Disorder; VAL: Valproate; W: Weeks; ZIPRA:

Ziprasidone. 


\section{AUTHOR DECLARATION FORM}

\section{Adis}

At submission, EVERY AUTHOR listed in the manuscript must READ and COMPLETE the following statements on:

(A) Authorship Responsibility, (B) Authorship Criteria, (C) Authorship Contribution, (D) Funding Disclosures,

(E) Contributor Disclosures/Acknowledgments, and (F) Conflicts of Interest Disclosures.

It is important that you return this form as early as possible in the publication process. EVERY AUTHOR MUST COMPLETE AN INDIVIDUAL COPY OF THE FORM, AND EVERY SECTION OF THE FORM MUST BE COMPLETED.

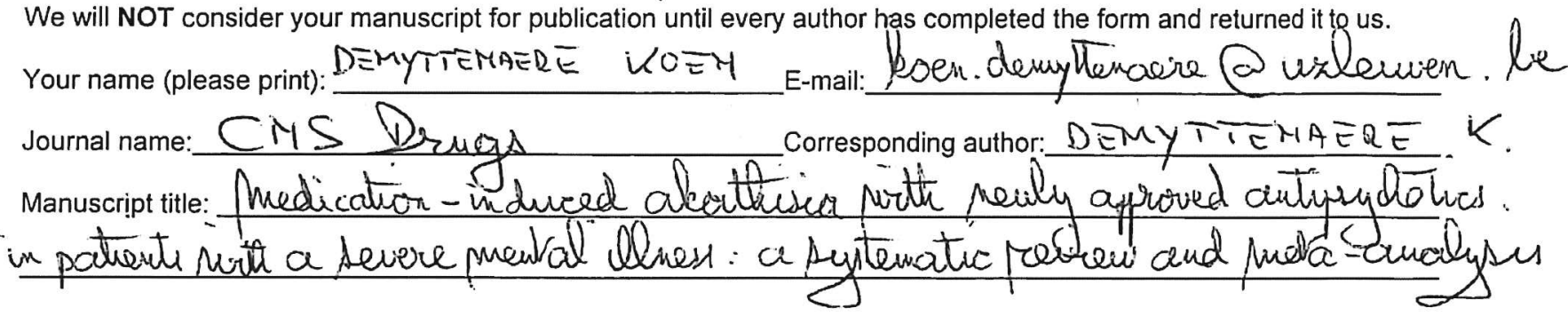

A. AUTHORSHIP RESPONSIBILITY

I certify that ALL of the following statements are correct (PLEASE CHECK THE BOX).

1. The manuscript represents valid work; neither this manuscript nor one with substantially similar content under my authorship has been published or is being considered for publication elsewhere (except as described in the manuscript submission); and copies of any closely related manuscripts are enclosed in the manuscript submission; AND

- For manuscripts with more than one author, I agree to allow the corresponding author to serve as the primary correspondent with the editorial office and to review and sign off on the final proofs prior to publication; or, if $I$ am the only author, I will be the corresponding author and agree to serve in the roles described above.

- For manuscripts that are a report of a study, I confirm that this work is an accurate representation of the trial results.

B. AUTHORSHIP CRITERIA

To fulfil all of the criteria for authorship, every author of the manuscript must have made substantial contributions to ALL of the following aspects of the work:

- Conception and planning of the work that led to the manuscript or acquisition, analysis and interpretation of the data, or both; $A N D$

- Drafting and/or critical revision of the manuscript for important intellectual content; AND

- Approval of the final submitted version of the manuscript.

1. I certify that I fulfill ALL of the above criteria for authorship (PLEASE CHECK THE BOX).

\section{AUTHORSHIP CONTRIBUTION}

I certify that I have participated sufficiently in the work to take public responsibility for (PLEASE CHECK 1 OF THE 2 BOXES BELOW):

$\square$ Part of the content of the manuscript; $O R$

The entire content of the manuscript.

D. FUNDING DISCLOSURES

PLEASE CHECK 1 OF THE 2 BOXES BELOW:

$\square$ I certify that no funding has been received for the conduct of this study and/or preparation of this manuscript; OR

$\bigotimes$ I certify that all financial and material support for the conduct of this study and/or preparation of this manuscript is clearly described in the Compliance with Ethical Standards section of the manuscript.

Some funding organizations require that authors of manuscripts reporting research deposit those manuscripts with an approved public repository.

$\square$ Please check here if you have received such funding.

\section{E. CONTRIBUTOR DISCLOSURES}

All persons who have made substantial contributions to the work reported in the manuscript (e.g. data collection, data analysis, or writing or editing assistance) but who do not fulfill the authorship criteria MUST be named with their specific contributions in the Acknowledgments section of the manuscript. Groups of persons who have contributed may be listed under a heading such as 'Clinical investigators' and their function described. Because readers may infer their endorsement of the manuscript, all persons named in the Acknowledgments section MUST give the authors their written permission to be named in the manuscript.

I certify that all persons who have made substantial contributions to this manuscript but who do not fulfill the authorship criteria are listed with their specific contributions in the Acknowledgments section in the manuscript, and that all persons named in the Acknowledgments section have given me written permission to be named in the manuscript. 


\section{F. CONFLICT OF INTEREST DISCLOSURES}

A conflict of interest exists when professional judgment concerning a primary interest (such as patients' welfare or the validity of research) may be influenced by a secondary interest (such as financial gain or personal rivalry). A conflict of interest may arise for authors when they have a financial interest that may influence - probably without their knowing their interpretation of their results or those of others. We believe that to make the best decision on how to deal with a manuscript we should know about any such conflict of interest that the authors may have. We are not aiming to eradicate conflicts of interests - they are almost inevitable. We will not reject manuscripts simply because the authors have a conflict of interest, but we will publish a declaration in the manuscript as to whether or not the authors have conflicts of interests.

All authors MUST complete the following checklist:

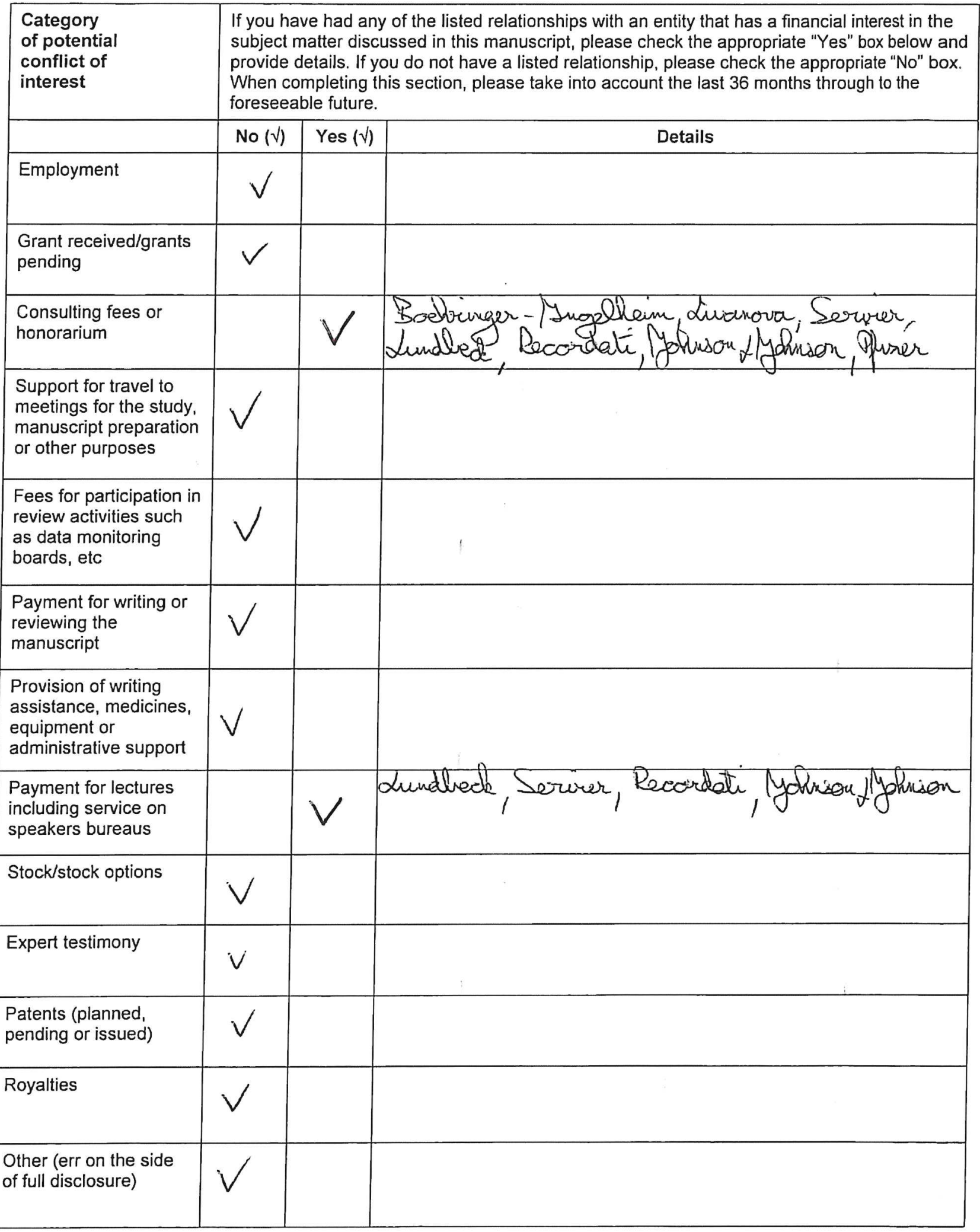


Every author MUST complete option 1 or option 2 as appropriate below. If you answered "Yes" to any of the questions relating to financial conflicts of interests in the table above (or if you wish to disclose a non-financial conflict of interest), you MUST write a suitable statement in the box below and include this statement in the Compliance with Ethical Standards section of the manuscript.

have no conflicts of interest to declare; $O R$

$\nabla$ The following statement regarding conflicts of interest and financial support for conduct of this study and/or preparation of this manuscript is to be published in the Compliance with Ethical Standards section of the manuscript:

we gonorell

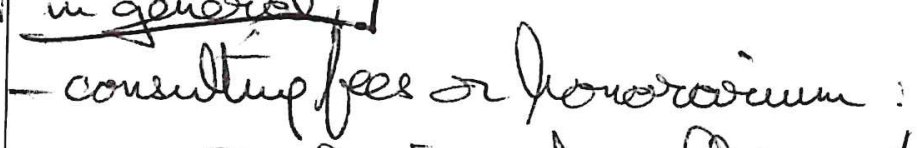

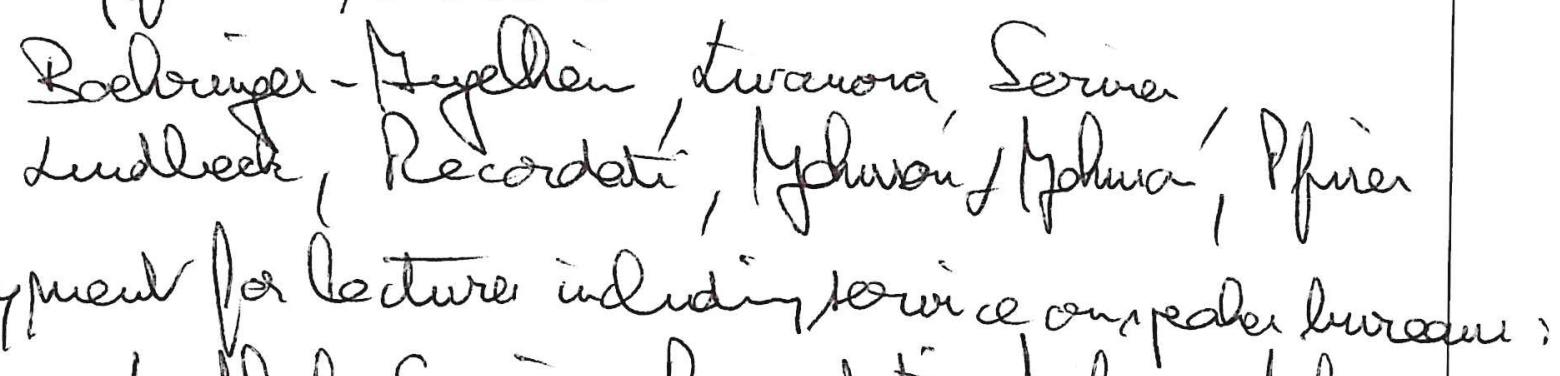
Lundbech, Sower, Recordati, Gehisonf f phon

Declaration: I certify that I have fully read and fully understood this form, and that the information that I have presented here is accurate and complete to the best of my knowledge.

Your name (please print) KOEM DEMYTTEMAERE Sign $29 / 10 / 2018$ 


\section{AUTHOR DECLARATION FORM}

At submission, EVERY AUTHOR llsted in the manuscript must READ and COMPLETE the following statements on:

(A) Authorship Responslbllity, (B) Authorshlp Criterla, (C) Authorship Contributlon, (D) Funding Disclosures,

(E) Contributor Disclosures/Acknowledgments, and (F) Confilcts of Interest Disclosures.

It is important that you retum this form as early as possible in the publlcatlon process. EVERY AUTHOR MUST COMPLETE AN INDIVIDUAL COPY OF THE FORM, AND EVERY SECTION OF THE FORM MUST BE COMPLETED. We will NOT consider your manuscript for publication untll every author has completed the form and retumed it to us.

Your name (please print): JOHAN DETRAUX E-mail: johan.detraux@upckuleuven.be

Joumal name: CNS Drugs Corresponding author: Koen Demyttenaere.

Manuscript ttle: Medlcatlon-induced akathlsla with newly approved antjpsychotles in patients wlth a severe mental IIIness: a systematic review and meta-analysis

\section{A. AUTHORSHIP RESPONSIBILITY}

\ I certify that ALL of the following statements are correct (PLEASE CHECK THE BOX).

- The manuscript represents valld work; neither this manuscript nor one with substantlally similar content under my authorship has been published or is belng considered for publlcatlon elsewhere (except as described in the manuscript submlssion); and coples of any closely related manuscripts are enclosed in the manuscript submission; AND

- For manuscripts with more than one author, I agree to allow the corresponding author to serve as the primary correspondent with the editorial office and to revlew and sign off on the final proofs prior to publication; or, if I am the only author, I will be the corresponding author and agree to serve in the roles described above.

- For manuscripts that are a report of a study, I confirm that this work ls an accurate representatlon of the tral results.

\section{B. AUTHORSHIP CRITERIA}

To fulfil all of the criteria for authorship, every author of the manuscript must have made substantial contributions to ALL of the following aspects of the work:

- Conception and planning of the work that led to the manuscript or acquisition, analysls and interpretation of the data, or both; AND

- Drafting and/or critical revision of the manuscript for important intellectual content; AND

- Approval of the final submilted version of the manuscript.

\ I certify that I fulfill ALL of the above criteria for authorship (PLEASE CHECK THE BOX).

\section{AUTHORSHIP CONTRIBUTION}

I certify that I have participated sufficlently in the work to take public responsibllity for (PLEASE CHECK 1 OF THE 2 BOXES BELOW:

Part of the content of the manuscript; OR

The entire content of the manuscript.

\section{FUNDING DISCLOSURES}

\section{PLEASE CHECK 1 OF THE 2 BOXES BELOW:}

I certify that no funding has been received for the conduct of this study and/or preparatlon of thls manuscript; OR I certify that all financial and material support for the conduct of this study and/or preparation of this manuscript Is clearly described in the Compliance with Ethical Standards section of the manuscript.

Some funding organizations require that authors of manuscripts reporting research deposit those manuscripts with an approved public reposttory.

D Please check here if you have received such funding.

\section{E. CONTRIBUTOR DISCLOSURES}

All persons who have made substantial contrlbutlons to the work reported in the manuscript (e.g. data collection, data analysis, or witting or editing assistance) but who do not fulfill the authorshlp criteria MUST be named with their specific contrlbutions in the Acknowledgments sectlon of the manuscript. Groups of persons who have contributed may be llsted under a heading such as 'Cllnical investigators' and their functlon described. Because readers may infer their endorsement of the manuscript, all persons named in the Acknowledgments sectlon MU\$T give the authors their witten permlssion to be named in the manuscript.

I certlfy that all persons who have made substantlal contributions to thls manuscript but who do not fulfill the authorship criterla are listed with their specific contributtons in the Acknowledgments section in the manuscript, and 
that all persons named In the Acknowledgments sectlon have given me wrltten permission to be named in the manuscript. 


\section{F. CONFLICT OF INTEREST DISCLOSURES}

A conflict of Interest exists when professional Judgment conceming a primary interest (such as patients' welfare or the validty of research) may be influenced by a secondary Interest (such as financlal gain or personal rivalry). A conflict of interest may arise for authors when they have a financial interest that may influence - probably without their knowing their Interpretation of thelr results or those of others. We believe that to make the best declision on how to deal with a manuscript we should know about any such confllct of Interest that the authors may have. We are not aiming to eradicate conflicts of interests - they are almost inevitable. We wlll not reject manuscripts simply because the authors have a conflict of interest, but we will publlsh a declaration In the manuscript as to whether or not the authors have conflicts of interests.

All authors MUST complete the following checklist:

\begin{tabular}{|c|c|c|c|}
\hline \multirow[t]{2}{*}{$\begin{array}{l}\text { Category } \\
\text { of potentlal } \\
\text { conflict of } \\
\text { Interest }\end{array}$} & \multicolumn{3}{|c|}{$\begin{array}{l}\text { If you have had any of the listed relatlonships with an ently that has a financial Interest In the } \\
\text { subject matter discussed In this manuscript, please check the appropriate "Yes" box below and } \\
\text { provlde details, If you do not have a listed relationshlp, please check the appropriate "No" box. } \\
\text { When completing this sectlon, please take Into account the last } 36 \text { months through to the } \\
\text { foreseeable future. }\end{array}$} \\
\hline & No $(\sqrt{ })$ & Yes $(v)$ & Detalls \\
\hline Employment & $x$ & & \\
\hline $\begin{array}{l}\text { Grant received/grants } \\
\text { pendling }\end{array}$ & $x$ & & \\
\hline $\begin{array}{l}\text { Consulting foes or } \\
\text { honorarium }\end{array}$ & $x$ & & \\
\hline $\begin{array}{l}\text { Support for travel to } \\
\text { meetings for the study, } \\
\text { manuscript preparation } \\
\text { or other purposes }\end{array}$ & $x$ & & \\
\hline $\begin{array}{l}\text { Fees for partlcipation in } \\
\text { revlew activlties such } \\
\text { as data monitoring } \\
\text { boards, etc }\end{array}$ & $x$ & & \\
\hline $\begin{array}{l}\text { Payment for writing or } \\
\text { reviewing the } \\
\text { manuscript }\end{array}$ & $x$ & & \\
\hline $\begin{array}{l}\text { Provision of writing } \\
\text { ass/stance, medlclnes, } \\
\text { equipment or } \\
\text { administrative support }\end{array}$ & $x$ & & \\
\hline $\begin{array}{l}\text { Payment for lectures } \\
\text { including service on } \\
\text { speakers bureaus }\end{array}$ & $x$ & & \\
\hline Stock/stock options & $x$ & & \\
\hline Expert testimony & $x$ & & \\
\hline $\begin{array}{l}\text { Patents (planned, } \\
\text { pendling or issued) }\end{array}$ & $x$ & & \\
\hline Royaltles & $x$ & & \\
\hline $\begin{array}{l}\text { Other (err on the side } \\
\text { of full dlsclosure) }\end{array}$ & $x$ & & \\
\hline
\end{tabular}


Every author MUST complete option 1 or option 2 as appropriate below. If you answered "Yes" to any of the questions relating to financlal conflicts of Interests In the table above (or if you wish to dlsclose a non-financial conflict of interest), you MUST write a suitable statement in the box below and include this statement in the Compliance with Ethical Standards section of the manuscript.

$\triangle$ I have no conflicts of interest to declare; OR

$\square$ The following statement regarding conflets of interest and financial support for conduct of this study and/or preparation of this manuscript is to be published In the Compllance with Ethical Standards sectlon of the manuscript:

Declaratlon: I certify that I have fully read and fully understood this form, and that the Information that I have presented here is accurate and complete to the best of my knowledge.

Your name (please print): Johan Detraux

Signature (please HAND-WRITE)

Date: 05-11-2018

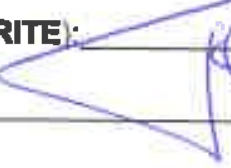




\section{AUTHOR DECLARATION FORM}

At submission, EVERY AUTHOR listed in the manuscript must READ and COMPLETE the following statements on:

(A) Authorship Responsibility, (B) Authorship Criteria, (C) Authorship Contribution, (D) Funding Disclosures,

(E) Contributor Disclosures/Acknowledgments, and (F) Conflicts of Interest Disclosures.

It is important that you return this form as early as possible in the publication process. EVERY AUTHOR MUST COMPLETE AN INDIVIDUAL COPY OF THE FORM, AND EVERY SECTION OF THE FORM MUST BE COMPLETED. consider your manuscript for publication until every author has completed the form and returned it to us.

Your name (please print): GIORGIO RACAGNI

E-mail: giorgio.racagni@unimi.it

Journal name: CNS DRUGS

Corresponding author: KOEN DEMYTTENAERE

Manuscript title: MEDICATION-INDUCED AKATHISIA WITH NEWLY APPROVED ANTIPSYCHOTICS IN PATIENTS WITH A SEVERE MENTAL ILLNESS: A SYSTEMATIC REVIEW AND META-ANALYSIS.

A. AUTHORSHIP RESPONSIBILITY

$x$ I certify that ALL of the following statements are correct (PLEASE CHECK THE BOX).

- The manuscript represents valid work; neither this manuscript nor one with substantially similar content under my authorship has been published or is being considered for publication elsewhere (except as described in the manuscript submission); and copies of any closely related manuscripts are enclosed in the manuscript submission; AND

- For manuscripts with more than one author, I agree to allow the corresponding author to serve as the primary correspondent with the editorial office and to review and sign off on the final proofs prior to publication; or, if I am the only author, I will be the corresponding author and agree to serve in the roles described above.

mascripts that are a report of a study, I confirm that this work is an accurate representation of the trial results.

B. AUTHORSHIP CRITERIA

To fulfil all of the criteria for authorship, every author of the manuscript must have made substantial contributions to ALL of the following aspects of the work:

- Conception and planning of the work that led to the manuscript or acquisition, analysis and interpretation of the data, or both; AND

- or both; $A N D$
- Drafting and/or critical revision of the manuscript for important intellectual content; AND
- Approval of the final submitted version of the manuscript.

$X$ I certify that I fulfill ALL of the above criteria for authorship (PLEASE CHECK THE BOX).

C. AUTHORSHIP CONTRIBUTION

I certify that I have participated sufficiently in the work to take public responsibility for (PLEASE CHECK 1 OF THE 2

BOXES BELOW):

$x$ Part of the content of the manuscript; OR

The entire content of the manuscript.

D. FUNDING DISCLOSURES

PLEASE CHECK 1 OF THE 2 BOXES BELOW:

$X$ I certify that no funding has been received for the conduct of this this study and/or preparation of this manuscript is I certify that all financial and material support for the conduct of this study and manuscript.
clearly described in the Compliance with Ethical Standards section of the mant

Some funding organizations require that authors of manuscripts reporting research deposit those manuscripts with an approved public repository.

Please check here if you have received such funding

E. CONTRIBUTOR DISCLOSURES

All persons who have made substantial contributions to the work reported in the manuscript (e.g. data collection, data analysis, or writing or editing assistance) but who do not fulfill the authorship criteria MUST be named with their specific contributions in the Acknowledgments section of the manuscript. Groups of persons who have contributed may be listed under a heading such as 'Clinical investigators' and their function described. Because readers may infer their endorsement of the manuscript, all persons named in the Acknowledgments section MUST give the authors their written permission to be named in the manuscript.

I certify that all persons who have made substantial contributions to this manuscript but who do not fulfill the authorship criteria are listed with their specific contributions in the Acknowledgments section in the manuscript, and that all persons named in the Acknowledgments section have given me written permission to be named in the manuscript. 
F. CONFLICT OF INTEREST DISCLOSURES

A conflict of interest exists when professional judgment concerning a primary interest (such as patients' welfare or the validity of research) may be influenced by a secondary interest (such as financial gain or personal rivalry). A conflict of interest may arise for authors when they have a financial interest that may influence - probably without their knowing interpation of their results or those of others. We believe that to make the best decision on how to deal with a manuscript we should know about any such conflict of interest that the authors may have. We are not aiming to eradicate conflicts of interests - they are almost inevitable. We will not reject manuscripts simply because the authors have a conflict of interest, but we will publish a declaration in the manuscript as to whether or not the authors have conflicts of interests.

All authors MUST complete the following checklist:

\begin{tabular}{|c|c|c|c|}
\hline \multirow[t]{2}{*}{$\begin{array}{l}\text { Category } \\
\text { of potential } \\
\text { conflict of } \\
\text { interest }\end{array}$} & \multicolumn{3}{|c|}{$\begin{array}{l}\text { If you have had any of the listed relationships with an entity that has a financial interest in the } \\
\text { subject matter discussed in this manuscript, please check the appropriate "Yes" box below and } \\
\text { provide details. If you do not have a listed relationship, please check the appropriate "No" box. } \\
\text { When completing this section, please take into account the last } 36 \text { months through to the } \\
\text { foreseeable future. }\end{array}$} \\
\hline & No $(\sqrt{ })$ & Yes $(\sqrt{ })$ & Details \\
\hline Employment & & $x$ & Professor of Pharmacology retired \\
\hline $\begin{array}{l}\text { Grant received/grants } \\
\text { pending }\end{array}$ & & $\mathrm{x}$ & Servier, Recordati \\
\hline $\begin{array}{l}\text { Consulting fees or } \\
\text { honorarium }\end{array}$ & & $x$ & Servier, Recordati \\
\hline $\begin{array}{l}\text { Support for travel to } \\
\text { meetings for the study, } \\
\text { manuscript preparation } \\
\text { or other purposes }\end{array}$ & $x$ & & \\
\hline $\begin{array}{l}\text { Fees for participation in } \\
\text { review activities such } \\
\text { as data monitoring } \\
\text { boards, etc }\end{array}$ & $x$ & & \\
\hline $\begin{array}{l}\text { Payment for writing or } \\
\text { reviewing the } \\
\text { manuscript }\end{array}$ & $x$ & & \\
\hline $\begin{array}{l}\text { Provision of writing } \\
\text { assistance, medicines, } \\
\text { equipment or } \\
\text { administrative support }\end{array}$ & $x$ & & \\
\hline $\begin{array}{l}\text { Payment for lectures } \\
\text { including service on } \\
\text { speakers bureaus }\end{array}$ & & $x$ & Servier, Recordati \\
\hline Stock/stock options & $x$ & & \\
\hline Expert testimony & $x$ & & \\
\hline $\begin{array}{l}\text { Patents (planned, } \\
\text { pending or issued) }\end{array}$ & $x$ & & \\
\hline Royalties & $x$ & & \\
\hline $\begin{array}{l}\text { Other (err on the side } \\
\text { of full disclosure) }\end{array}$ & & & \\
\hline
\end{tabular}


Every author MUST complete option 1 or option 2 as appropriate below. If you answered "Yes" to any of the questions nancial conflicts of interests in the table above (or if you wish to disclose a non-financial conflict of interest), you MUST write a suitable statement in the box below and include this statement in the Compliance with Ethical Standards section of the manuscript.

I have no conflicts of interest to declare; $O R$

$x$ The following statement regarding conflicts of interest and financial support for conduct of this study and/or preparation of this manuscript is to be published in the Compliance with Ethical Standards section of the manuscript:

Giorgio Racagni declares that he has received personal fees from Servier and Recordati

Declaration: I certify that I have fully read and fully understood this form, and that the information that I have presented here is accurate and complete to the best of my knowledge.

Your name (please print): GIORGIO RACAGNI

Signature (please HAND-WRITE):

Date: October 25th, 2018

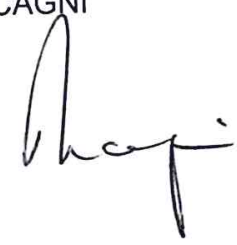




\section{AUTHOR DECLARATION FORM}

\section{$\triangle$ Adis}

At submission, EVERY AUTHOR llgted In the manuscript must READ and COMPLETE the following statements on:

(A) Authorshlp Responsibllity, (B) Authorshlp Criterla, (C) Authorshlp Contributlon, (D) Funding Disclosures,

(E) Contributor Dlsclosures/Acknowledgments, and (F) Confilcts of Interest Dlsclosures.

It is important that you retum this form as early as possible in the publication process. EVERY AUTHOR MUST COMPLETE AN INDIVIDUAL COPY OF THE FORM, AND EVERY SECTION OF THE FORM MUST BE COMPLETED. We will Not consider your manuscript for publication until every author has completed the form and retumed it to us.

Your name (please print): VANSTEELANDT KRISTOF $\quad$ E-mall:Krlstof.Vansteelandt@upckuleuven.be

Joumal name: CNS Drugs Corresponding author. Koen Demyttenaere

Manuscript title: Medication-induced akathisia with newly approved antipsychotics in patients with a severe mental

illness: a systematic revlew and meta-analysls.

A. AUTHORSHIP RESPONSIBILITY

$X$ I certify that ALL of the following statements are correct (PLEASE CHECK THE BOX).

- The manuscript represents valid work; neither this manuscript nor one with substantially similar content under my authorship has been published or is being considered for publication elsewhere (except as descrlbed In the manuscript submlssion); and copies of any closely related manuscripts are enclosed in the manuscript submission; AND

- For manuscripts with more than one author, I agree to allow the corresponding author to serve as the primary correspondent with the edltorial office and to review and sign off on the final proofs prior to publication; or, If I am the only author, I will be the corresponding author and agree to serve in the roles described above.

- For manuscripts that are a report of a study, I confirm that this work is an accurate representation of the trial results.

\section{B. AUTHORSHIP CRITERIA}

To fulfil all of the criterla for authorshlp, every author of the manuscript must have made substantial contributions to ALL of the following aspects of the work:

- Conceptlon and planning of the work that led to the manuscript or acquisition, analysis and interpretation of the data, or both; $\boldsymbol{A N D}$

- Drafting and/or crttical revlslon of the manuscript for important intellectual content; $A N D$

- Approval of the final submitted version of the manuscript.

$X$ I certify that I fulfill ALL of the above criterla for authorshlp (PLEASE CHECK THE BOX).

\section{AUTHORSHIP CONTRIBUTION}

I certify that I have participated sufficlently in the work to take publlc responsibllity for (PLEASE CHECK 1 OF THE 2 BOXES BELOW):

$X$ Part of the content of the manuscript; $O R$

$\square$ The entire content of the manuscript.

D. FUNDING DISCLOSURES

PLEASE CHECK 1 OF THE 2 BOXES BELOW:

$X$ I certify that no funding has been received for the conduct of this study and/or preparation of this manuscript; $O R$

$\square$ I certify that all financial and materlal support for the conduct of this study and/or preparation of this manuscript is clearly described in the Compliance with Ethlcal Standards section of the manuscript.

Some funding organlzatlons require that authors of manuscripts reporting research deposit those manuscripts with an approved public repository.

$\square$ Please check here If you have received such funding.

\section{E. CONTRIBUTOR DISCLOSURES}

All persons who have made substantial contrlbutions to the work reported in the manuscript (e.g. data collection, data analysis, or wrlting or editing assistance) but who do not fulfill the authorship criterla MUST be named with their speclfic contributions in the Acknowledgments section of the manuscript. Groups of persons who have contributed may be listed under a heading such as 'Clnical Investigators' and thelr functlon described. Because readers may infer their' endorsement of the manuscript, all persons named in the Acknowledgments section MUST give the authors their written permission to be named in the manuscript.

$X$ I certify that all persons who have made substantial contributions to this manuscript but who do not fulfill the authorship criteria are llsted with their specific contrlbutions in the Acknowledgments section in the manuscript, and that all persons named In the Acknowledgments section have glven me wiltten permission to be named in the manuscript.

\section{F. CONFLICT OF INTEREST DISCLOSURES}


A conflict of Interest exists when professional judgment conceming a primary interest (such as patients' welfare or the validlty of research) may be influenced by a secondary interest (such as financial gain or personal rivalry). A conflict of Interest may arlse for authors when they have a financial Interest that may Influence - probably without their knowing their interpretation of thelr results or those of others. We believe that to make the best decision on how to deal with a manuscript we should know about any such conflict of Interest that the authors may have. We are not aiming to eradicate conflicts of interests - they are almost inevitable. We wll not reject manuscripts simply because the authors have a conflict of Interest, but we will publish a declaration in the manuscript as to whether or not the authors have conflicts of interests.

\section{All authors MUST complete the following checklist:}

\begin{tabular}{|c|c|c|c|}
\hline \multirow[t]{2}{*}{$\begin{array}{l}\text { Category } \\
\text { of potentlal } \\
\text { conflict of } \\
\text { Interest }\end{array}$} & \multicolumn{3}{|c|}{$\begin{array}{l}\text { If you have had any of the llsted relatlonships with an entity that has a financial interest in the } \\
\text { subject matter dlscussed in this manuscript, please check the appropriate "Yes" box below and } \\
\text { provide details. If you do not have a listed relationship, please check the appropriate "No" box. } \\
\text { When completing this section, please take Into account the last } 36 \text { months through to the } \\
\text { foreseeable future. }\end{array}$} \\
\hline & No $(\sqrt{ })$ & Yes $(\sqrt{ })$ & Detalle \\
\hline Employment & $x$ & & \\
\hline $\begin{array}{l}\text { Grant received/grants } \\
\text { pending }\end{array}$ & $x$ & & \\
\hline $\begin{array}{l}\text { Consulting fees or } \\
\text { honorarium }\end{array}$ & $x$ & & \\
\hline $\begin{array}{l}\text { Support for travel to } \\
\text { meetings for the study, } \\
\text { manuscript preparation } \\
\text { or other purposes }\end{array}$ & $x$ & & \\
\hline $\begin{array}{l}\text { Fees for participation In } \\
\text { revlew activities such } \\
\text { as data monltoring } \\
\text { boards, etc }\end{array}$ & $x$ & & \\
\hline $\begin{array}{l}\text { Payment for writling or } \\
\text { reviewing the } \\
\text { manuscript }\end{array}$ & $x$ & & \\
\hline $\begin{array}{l}\text { Provislon of writing } \\
\text { assistance, medicines, } \\
\text { equlpment or } \\
\text { administrative support }\end{array}$ & $x$ & & \\
\hline $\begin{array}{l}\text { Payment for lectures } \\
\text { Including servlce on } \\
\text { speakers bureaus }\end{array}$ & $x$ & & \\
\hline Stock/stock options & $x$ & & \\
\hline Expert testlmony & $x$ & & \\
\hline $\begin{array}{l}\text { Patents (planned, } \\
\text { pending or issued) }\end{array}$ & $x$ & & \\
\hline Royalties & $x$ & & \\
\hline $\begin{array}{l}\text { Other (err on the side } \\
\text { of full dlsclosure) }\end{array}$ & $x$ & & \\
\hline
\end{tabular}


Every author MUST complete option 1 or option 2 as appropriate below. If you answered "Yes" to any of the questions relating to financlal conflcts of interests In the table above (or if you wish to disclose a non-financlal conflict of interest), you MUST wilte a sultable statement in the box below and include this statement in the Compllance with Ethical Standards section of the manuscript.

X I have no confilcts of Interest to declare; OR

$\square$ The following statement regarding conflicts of interest and financial support for conduct of thls study and/or preparation of thls manuscript ls to be published in the Compliance with Ethical Standards section of the manuscript:

Declaration: I certify that I have fully read and fully understood this form, and that the information that I have presented here is accurate and complete to the best of my knowledge.

Your name (please print): Vansteelandt Kristof

Signature (please HAND-WRITE):

Date:25/10/2018

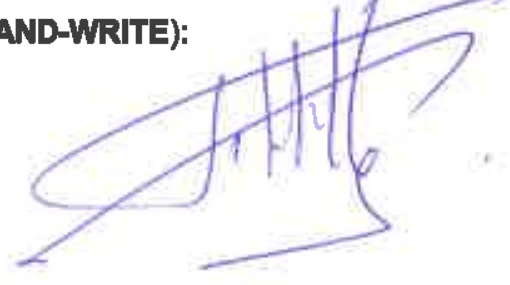

